\title{
SURGIMIENTO DE UN DERECHO AMERICANO DE LOS DERECHOS HUMANOS EN AMÉRICA LATINA
}

\section{EMERGENCE OF AN AMERICAN HUMAN RIGHTS LAW IN LATIN AMERICA}

\section{Gonzalo Aguilar CAVAllo*}

RESUMEN: En América Latina ha existido una gran simetría entre los procesos democratizadores de los años ochenta y noventa y la aceptación, por parte de los países de la región, de la jurisdicción de la Corte Interamericana de Derechos Humanos. A mi juicio, este último hecho ha estimulado el surgimiento de un Derecho Americano de los Derechos Humanos. El Derecho Americano de los Derechos Humanos se nutriría de las tradiciones constitucionales comunes de los Estados americanos y de los instrumentos internacionales de derechos humanos. El Derecho Americano de los Derechos Humanos demarcaría un espacio de orden público americano. Actualmente, las características fundamentales de este orden jurídico serían la promoción y protección de los derechos económicos, sociales y culturales y de la diversidad cultural. Una debilidad moderada del sistema se encuentra en el cumplimiento de las sentencias de la Corte Interamericana de Derechos Humanos.

Palabras claves: derechos humanos, derecho internacional de los derechos humanos, derecho constitucional..

* Profesor de tiempo completo del Departamento de Derecho del Instituto Tecnológico Autónomo de México.
ABSTRACT: There has been a great symmetry between the 80th and 90th democratic processes and the acceptation of the Inter-American Court of Human Rights' jurisdiction by Latin-American States. The latter has fostered the emergence of American Human Rights Law. American Human Rights Law would be fed on states' common constitutional traditions and international human rights instruments. The American Human Rights Law would delimit an American space of public order. Nowadays, the main features of this legal order would be the promotion and protection of economic, social and cultural rights and cultural diversity. A weakness of this legal order lies in the due observance of the Inter-American Court of Human Rights' decisions..

Descriptors: human rights, international human rights law, constitutional law. 


\section{INTRODUCCIÓN}

Una de las características más notables del proceso democratizador latinoamericano, es la simetría entre la transición a la democracia de los años ochenta y noventa y de normalidad constitucional, y la aceptación por parte de los países de la región, de la jurisdicción de la Corte Interamericana de Derechos Humanos (en adelante, la Corte IDH). Esto último resulta de la más alta relevancia, ya que el sometimiento de un Estado al escrutinio de un órgano jurisdiccional internacional en cuanto al cumplimiento efectivo de los derechos humanos en la jurisdicción de dicho Estado, representa una demostración patente y relevante de la madurez y solidez democrática constitucional de ese Estado. En este sentido, se puede expresar que se entiende por sociedad democrática aquella que funciona sobre la base de la división de los tres poderes y cuyo eje principal lo constituyen los derechos humanos también llamados derechos fundamentales.1 Así, el sistema interamericano de promoción y protección de los derechos humanos en particular, se erige como un catalizador del nivel de cumplimiento, por parte de los Estados, de los derechos humanos garantizados en sus propias Constituciones, las cuales contienen "la ventana por donde ingresa el haz de luz" del derecho internacional de los derechos humanos (en adelante, el DIDH). Esta apertura, ampliación y optimización de los derechos humanos, en el orden interno de los Estados, por medio del DIDH, refuerza la ya consolidada posición de estos en el derecho constitucional latinoamericano contemporáneo.

El avance de los derechos humanos en el mundo contemporáneo ha transformado las concepciones tradicionales de la soberanía, diluyendo las estrictas fronteras del Estado y convirtiéndolas en zonas de interacción e interrelación entre el orden jurídico interno y el orden jurídico internacional. Incluso, algunos autores se han referido a una nueva realidad jurídica global y expresan la necesidad, para esta nueva realidad, de un Estado de derecho global. ${ }^{2}$

1 Feddersen Martínez, Mayra, "Responsabilidad civil y actividad periodística en Chile", Cuadernos de Análisis Jurídicos, IV, 2008, pp. 71-94, especialmente, p. 71.

2 Cassese, Sabino, "Administrative Law without the State? The Challenge of Global Regulation", N.Y.U. Journal of International Law and Politics, vol. 37, 2005, pp. 663694; Palombella, Gianluigi, "The Rule of Law beyond the State: Failures, Promises, and Theory", International Journal of Constitutional Law, vol. 7, num. 3, 2009, pp. 442-467. 
Pese a lo anterior, subsisten autores que realzan la soberanía de los Estados frente a los derechos humanos. ${ }^{3}$ Sin embargo, creemos que la posición mayoritaria reside en los que reconocen que el sistema del Estado-nación se encuentra en evolución mutativa y que la concepción de la soberanía vigente con anterioridad a la Segunda Guerra Mundial, actualmente está superada. ${ }^{4}$ En este sentido, Biaggini ha destacado la creciente importancia que ha jugado el derecho internacional en relación con el derecho constitucional, cuando ha señalado que:

[d]esde el final de la Segunda Guerra Mundial, el derecho internacional alcanza en la solución de los problemas del presente, que ya no se paran en su mayoría en las fronteras nacionales, un enorme incremento de su significación. Sin embargo, parece exagerado, hoy, hablar de una verdadera disolución de la estatalidad o de la Constitución, si bien los concretos Estados y sus estructuras constitucionales no dejan de ser afectados por este proceso. La soberanía en el sentido clásico ya no corresponde a los Estados constitucionales iusinternacionalmente vinculados de formas diversas. ${ }^{5}$

A este último respecto, Ferrajoli ha señalado que:

en la historia de las relaciones internacionales con la institución de la ONU y de las cartas internacionales de derechos humanos, se produjo una ruptura de las que hacen época. La ruptura de ese Ancien Régime internacional nacido hace tres siglos de la paz de Westfalia, fundado en el principio de la soberanía absoluta de los Estados y que fue a quebrar con la tragedia de las dos guerras mundiales. ${ }^{6}$

3 Fuentes Torrijos, Ximena, "El derecho internacional y el derecho interno: definitivamente una pareja dispareja", http://www.law.yale.edu/documents/pdf/sela/XimenaFuentes_Spanish_pdf[consultado el 19 de octubre de 2009].

4 Cassese, Antonio, International Law, 2a. ed., Oxford, Oxford University Press, 2005, p. 217; Rosenfeld, Michel y Ruiz Fabri, Hélène, "Rethinking Constitutionalism in an Era of Globalization and Privatization", International Journal of Constitutional Law, vol. 6, núms. 3-4, 2008, pp. 371 y 372; Palombella, Gianluigi, "The Rule of Law beyond the State: Failures, Promises, and Theory", International Journal of Constitutional Law, vol. 7, núm. 3, 2009, pp. 442-467.

5 Biaggini, Giovanni, "La idea de Constitución: ¿nueva orientación en la época de la globalización?", Anuario Iberoamericano de Justicia Constitucional, núm. 7, 2003, pp. 43-75, especialmente, p. 51.

6 Ferrajoli, Luigi, Derechos y garantías. La ley del más débil, Madrid, Trotta, 1999, p. 55. 
El carácter angular de los derechos humanos en el derecho constitucional — comúnmente denominados en esta disciplina "derechos fundamentales"-7 es una idea bastante antigua. En efecto, Smend había señalado ya en 1928 que los derechos fundamentales "representan la norma que rige a la Constitución, la legislación y la Administración” y además que:

la legitimidad que proporciona el sistema de los derechos fundamentales constituye una definición del ordenamiento jurídico positivo y (sic) una de las principales tareas del derecho consiste en concretar el tipo y el grado de legitimidad que posee un ordenamiento jurídico positivo. ${ }^{8}$

Por otra parte, tal como ha señalado Pérez Luño,

[n]o es tampoco ocioso recordar que el célebre art. 16 de la Declaración de los derechos del hombre y del ciudadano de 1789, considerada como uno de los textos fundacionales del Estado de derecho, proclamaba: "toda sociedad en la cual la garantía de los derechos no está asegurada, ni la separación de poderes establecida carece de Constitución. El Estado de derecho es, a tenor de ello un Estado constitucional, pero no todo Estado que posee una Constitución es un Estado de derecho. ${ }^{9}$

En este sentido y respecto de los derechos fundamentales, resulta muy asertivo cuando Ferrajoli señala que "[e]l paradigma de la democracia constitucional no es otro que la sujeción del derecho al derecho", y nosotros precisaríamos, la sujeción del derecho a los derechos. ${ }^{10}$

América Latina ha experimentado interesantes avances y también retrocesos en su evolución política-constitucional de las últimas tres décadas. Sin embargo, uno de los aspectos que merece actualmente mayor atención son los procesos constituyentes que han vivido recientemente Venezuela,

7 Aguilar Cavallo, Gonzalo, "Derechos humanos y derechos fundamentales: ¿una distinción válida en el siglo XXI?”, Boletín Mexicano de Derecho Comparado, nueva serie, ano XLIII, núm.127, enero-abril de 2010, pp.15-71.

8 Smend, Rudolf, Constitución y derecho constitucional, trad. de de José María Beneyto Pérez, Madrid, Centro de Estudios Constitucionales, 1985, pp. 231 y 233.

9 Pérez Luño, Antonio-Enrique, "Estado constitucional y generaciones de derechos humanos", Corte Interamericana de Derechos Humanos, Liber Amicorum Héctor Fix Zamudio, San José de Costa Rica, CIDH, 1998, vol. II, pp. 1241-1264, especialmente, p. 1255.

${ }^{10}$ Ferrajoli, Luigi, Derechos..., cit., p. 52. 
Ecuador y Bolivia, y que podrían atravesar otros países de la región. Estos procesos han traído como consecuencia directa, nuevas Constituciones, con un grado avanzado de reconocimiento y desarrollo de los derechos humanos, en particular, de los derechos económicos, sociales y culturales (en adelante, DESC), configurándose así, desde una perspectiva formal, como Constituciones muy avanzadas y protectoras - incluso a nivel mundial - en esta materia. El problema es, en términos simples, que mientras en otros países que han alcanzado un avanzado estado de cumplimiento de los DESC, ello se ha logrado sin necesidad de una reforma a la constitución y muchas veces con simples y escuetas elaboraciones de principios sociales generales contenidos en sus cartas fundamentales. En América Latina, incluso mediante reformas constitucionales y amplios desarrollos normativos, ni así se obtiene que los Estados —en la práctica y en el cotidiano constitucional - cumplan y satisfagan plenamente los DESC.

Dicho de otro modo, de manera predominante, en América Latina, el problema más acuciante es la brecha de implementación y el del goce efectivo de los derechos humanos, sin distinción alguna. En consecuencia, podemos enfrentarnos a Constituciones que contengan un amplio catálogo de derechos, sin que estos derechos sean efectivamente respetados y susceptibles de tutela en la práctica, y en este aspecto, se podrían denominar cartas fundamentales "semánticas". A este propósito, podemos referirnos a la tipología de las Constituciones desarrollada por Loewenstein, quien opone las Constituciones normativas, aquellas que son "efectivamente vividas" por destinatarios y detentadores del poder, necesitando un ambiente nacional favorable para su realización, a las Constituciones semánticas, que son una especie de "disfraz" retórico de unas realidades del todo ajenas a las formas normativas constitucionales. ${ }^{11}$

En este trabajo, pretendemos abordar la interrogante de si, como consecuencia de la evolución político, social e institucional de América Latina en las últimas tres décadas, y producto de la interacción del sistema de protección interamericano de derechos humanos y de sus órganos, con los Estados y sus ordenamientos, ha surgido, aun de manera emergente, un cuerpo común de principios, normas y estándares, en el orden de los derechos humanos, que es compartido por los Estados latinoamericanos. Nuestro planteamiento es que, al menos de manera incipiente, comienza

11 Loewenstein, Karl, Teoría de la Constitución, 3a. reimp. de la 2a. ed., trad. de Alfredo Gallego Anabitarte, Barcelona, Ariel, 1983, pp. 217 y 219. 
a surgir lo que podríamos denominar un derecho americano de los derechos humanos (en adelante, el DADH). En cuanto a tipos de derechos reconocidos y contenido de los derechos, este Derecho varía, por ejemplo, del derecho europeo de los derechos humanos (en adelante, el DEDH). Este DADH es, por supuesto, DIDH, pero presenta algunos rasgos particulares. Por una lado, quizás hay derechos que el sistema interamericano de protección de los derechos humanos - en particular, una Corte Internacional de Derechos Humanos - ha abordado ex novo (como los derechos de los pueblos indígenas) y, por otro lado, también es posible que la Corte IDH trate los mismos derechos que la Corte Europea de Derechos Humanos (en adelante, la Corte EDH), pero que la Corte IDH los interprete y defina el contenido normativo de manera diferente. Todo esto sirve para contribuir a la singularidad del DADH.

Cuando hablamos del DADH nos estamos refiriendo a aquellas normas, principios y estándares que han ido surgiendo producto del establecimiento de un sistema interamericano de protección de los derechos humanos y, particularmente, a partir de la actividad de la Corte IDH, ${ }^{12}$ y que constituyen los rasgos definidores o distintivos de los derechos humanos en el continente americano.

Desde un punto de vista metodológico, se debe señalar que nuestro planteamiento no es un planteamiento formal sino material y substancial. Por esta razón no se efectúa una comparación en aspectos formales con los otros sistemas de protección regional de los derechos humanos o con el sistema de protección universal de los derechos humanos. No es el sistema interamericano de protección de los derechos humanos que nosotros queremos relevar en este trabajo, como distinto o diferente de los otros, sino más bien el corazón del presente trabajo es el DADH. No se trata de comparar mecanismo de protección, sino la existencia de un derecho que posee características particulares. Tampoco se trata de relevar la existencia de un derecho que ha surgido a partir de las experiencias

12 La Corte Interamericana de Derechos Humanos fue creada por la Convención Americana sobre Derechos Humanos de 1969 y fue establecida, luego de que dicha Convención entrará en vigor, con fecha 22 de mayo de 1979 durante el 7o. periodo extraordinario de sesiones de la Asamblea General de la OEA. E1 22 de mayo de 1979 los Estados Partes en la Convención Americana eligieron a los juristas que serían los primeros jueces que compondrían la Corte Interamericana. La primera reunión de la Corte se celebró el 29 y 30 de junio de 1979 en la sede de la OEA en Washington D.C. 
nacionales, sino más bien de identificar un derecho que emana de los órganos de control del sistema interamericano, que posee particularidades y que se proyecta a los diferentes ordenes estatales. En consecuencia, tampoco se estudiará la legislación y la jurisprudencia nacional sino en cuanto sirva para ejemplarizar las influencias del sistema interamericano en el orden estatal.

En otras palabras, cabe tener presente que el planteamiento dice relación con un DADH que ha surgido a partir de la actividad de los órganos del sistema interamericano de protección de los derechos humanos, no de un derecho que surge a partir de la identificación de rasgos distintivos comunes en la legislación y en la jurisprudencia de los Estados latinoamericanos. Los rasgos distintivos del DADH vienen determinados por la actividad de los órganos de control del sistema interamericano de protección y su interacción con los órganos jurisdiccionales nacionales latinoamericanos.

Se ha concentrado el área geográfica de referencia a los países latinoamericanos de habla portuguesa o española. Se excluye de esta hipótesis $\mathrm{y}$, por tanto, del presente análisis a los países pertenecientes al sistema jurídico del common law, vale decir, Estados Unidos y Canadá y los países angloparlantes del Caribe. Junto con lo anterior, se han dejado fuera Estados de lengua francesa como Haití y las dependencias francesas de America. Además, países de lengua no latina, como Surinam y Guayana Británica en America del Sur, y Belice en America Central, y el Caribe. Una justificación para excluirlos es que la mayoría de esos países no son partes en el Pacto de San José. Esta elección se ha hecho pensando que estos países latinoamericanos comparten raíces históricas, sociales y culturales - en gran medida - comunes y que, además, tienen una visión y una aproximación a los derechos humanos compartida. Por lo tanto, cuando en este trabajo se hable del DADH, debe entenderse efectuada dicha referencia al grupo de países y los órdenes jurídicos que se han mencionado anteriormente.

Este estudio se encuentra dividido en dos partes principales, la primera abordará el proceso de surgimiento del DADH y los rasgos principales de este orden jurídico y, con posterioridad, se examinará la influencia e interacción del sistema interamericano de promoción y protección de los derechos humanos con los órdenes nacionales, como factor principal en el surgimiento de este DADH. 


\section{APARICIÓN Y CARACTERÍSTICAS DE UN DERECHO AMERICANO DE LOS DERECHOS HUMANOS}

Para la verdadera generación de un derecho americano de los derechos humanos (DADH), es necesario superar la separación — que como se ha visto es primordialmente conceptual y política - entre derechos fundamentales y derechos humanos, y reconocer que existe un sólo orden jurídico - unitario y coherente- de los derechos humanos, y que este orden jurídico es el mismo para el individuo, los grupos y pueblos, ya sea que se encuentren al interior de la jurisdicción y esfera de acción de la Constitución o sujetos al ámbito de acción del derecho internacional. ${ }^{13}$ Como hemos dicho, los Estados pueden tener especificidades en materia de derechos humanos, frente al derecho internacional, representando de esta manera, el derecho constitucional y el derecho internacional, elementos plurales de un mismo orden jurídico, esto es, el derecho de los derechos humanos y, en el ámbito americano, el DADH.

En este contexto, sobre la progresiva penetración y compenetración del DIDH con el orden constitucional, Biaggini ha señalado que:

[f]unciones que hasta ahora la Constitución nacional cumplía ella sola más o menos - protección de las libertades, garantía de la paz, limitación del poder, etcétera- son prolongadas cada vez más a escala supraestatal en forma de agrupaciones de derecho internacional y de organizaciones internacionales y supranacionales. Casi se intenta hablar de una outsourcing parcial de funciones constitucionales. La Constitución, a la que frecuentemente se califica como introvertida, se vuelve "hacia fuera". La Constitución se hace más internacional y el derecho internacional se hace más constitucional. ${ }^{14}$

En el caso del continente americano, este derecho de los derechos humanos ha ido forjándose y moldeándose, como se verá a continuación, a raíz del surgimiento del sistema interamericano de promoción y protección de los derechos humanos, de la actividad de sus órganos y de la interacción con los ordenamientos estatales, primordialmente, por medio de la interactividad con el orden constitucional y la jurisdicción constitucional de los Estados.

13 Aguilar Cavallo, Gonzalo, op. cit.

14 Biaggini, Giovanni, op. cit., pp. 53 y 54. 


\section{Forjamiento}

En América Latina, nadie puede ignorar que la normativa correspondiente al DIDH ha penetrado con fuerza el orden interno de los Estados, permeando y, a su vez, empapando el derecho constitucional — sus valores, principios y espíritu - y generando, desde la perspectiva de los derechos humanos, una unidad jurídica coherente protectora del individuo, de los grupos y pueblos. ${ }^{15}$ Esto es lo que algunos autores han denominado la internacionalización del derecho constitucional. ${ }^{16}$ En este contexto, tal como lo ha afirmado el Tribunal Constitucional chileno, "todos los valores, principios y normas articulados en [la Constitución] gozan de la supremacía que caracteriza a tal ordenamiento jurídico-político". ${ }^{17}$

Así, el derecho de los derechos humanos - en el orden interno de los Estados-, se compone hoy, de la confluencia enriquecedora entre el derecho internacional y el derecho constitucional. ${ }^{18}$ El profesor Martín-Retortillo lo

15 "El reconocimiento explícito, por parte de nuestra más elevada instancia jurisdiccional constitucional, del carácter "sistemático" de nuestra tabla de derechos fundamentales deja abierta la consideración de importantes cuestiones" [...] "La Constitución ( sic), como norma suprema de un Estado de derecho desarrollado, al apelar a la noción de ordenamiento jurídico no hace sino reconocer que el conjunto de reglas que integran su derecho positivo objetivo responde a los principios básicos de: unidad, plenitud y coherencia". Pérez Luño, Antonio-Enrique, "Dogmática de los derechos fundamentales y transformaciones del sistema constitucional”, Teoría y Realidad Constitucional, núm. 20, 2007, pp. 495-511, especialmente, p. 498.

16 "Hoy día es posible constatar todo un proceso de internacionalización e integración progresiva del sistema de derechos fundamentales en los diferentes ordenamientos nacionales". Álvarez Conde, Enrique y Tur Ausina, Rosario, "Los derechos en el constitucionalismo: tipología y tutela «multilevel»", Teoría y Realidad Constitucional, núm. 20, 2007, pp. 231-276, especialmente, p. 232; véase Aguilar Cavallo, Gonzalo, "La internacionalización del derecho constitucional”, Estudios Constitucionales, año 5, núm. 1, 2007, pp. 223-281.

17 Tribunal Constitucional de Chile, Requerimiento de inaplicabilidad deducido por Silvia Peña Wasaff respecto del artículo 38 ter de la Ley $N^{o} 18.933$, conocida como Ley de Isapres, en recurso de protección contra Isapre ING Salud S.A., Rol de Ingreso $4972-$ 2007, de la Corte de Apelaciones de Santiago, Rol 976-2007, Sentencia del 26 de junio de 2008 , párrafo $25^{\circ}$.

18 “.... a partir del presente deberá acomodar su óptica de enfoque hacia unos ordenamientos jurídicos policéntricos. Esta nueva perspectiva metodológica para asumir el significado actual de los sistemas jurídicos, denuncia la crisis del iuspositivismo kelseniano. Impone sustituir la imagen piramidal, es decir, jerarquizada del orden normativo, por un horizonte en el que la totalidad del sistema se obtendrá por la intersección de una pluralidad de estructuras normativas, de procedencia heterogénea y que hacinadas forma- 
ha dicho claramente cuando se refiere a "la actual realidad de los derechos humanos, esa especie de polifonía propia de la pluralidad de fuentes" ${ }^{19} \mathrm{En}$ otras palabras, desde la perspectiva de los derechos humanos, y en el ámbito americano, el derecho constitucional corresponde o debería corresponder al DADH. Por lo tanto, se podría sostener que se ha superado, aquella vieja concepción de que "los derechos fundamentales nacen con la Constitución y se acaban con la Constitución". ${ }^{20}$

Todo lo anterior no es sino una manifestación de un fenómeno mucho mayor, propio de la realidad jurídica contemporánea que refleja un mundo global e integrado jurídicamente. Esto significa que en el mundo moderno el juez nacional, al fallar sobre un caso concreto, debe enfrentarse a una pluralidad de órdenes normativos todos actualmente vigentes dentro de un espacio jurídico determinado y que se superponen unos sobre otros. Esta superposición es meramente figurativa y no indicativa de la jerarquía de los ordenes jurídicos, salvo en aquellos casos en que se hubiera adoptado una decisión especifica en respecto de dicha jerarquía - por ejemplo, el caso del derecho europeo- o en aquellos casos donde se trate de normas imperativas de derecho internacional general o normas de ius cogens. Lo anteriormente dicho, implica un cambio de paradigma en la solución de conflictos jurídicos con la aplicación potencial de diversos (dos o más) órdenes jurídicos.

Esta nueva perspectiva metodológica para asumir el significado actual de los sistemas jurídicos, denuncia la crisis del iuspositivismo kelseniano. En este sentido, el profesor von Bogdandy ha afirmado claramente que la vieja imagen piramidal de la estructura está moribunda. ${ }^{21}$ También ha dado cuenta de este cambio de paradigma el profesor Pérez Luño, aun cuando en un sentido ligeramente distinto. En efecto, el profesor español ha señalado que:

rán un panorama del ordenamiento jurídico bastante parecido a una bóveda". Pérez Luño, Antonio-Enrique, op. cit., nota 16, p. 510.

19 Martín-Retortillo Baquer, Lorenzo, Vias concurrentes para la protección de los derechos humanos, Navarra, Thomson-Civitas, 2006, p. 46.

${ }^{20}$ Cruz Villalón, Pedro, "Formación y evolución de los derechos fundamentales", Revista Española de Derecho Constitucional, Año 9. núm. 25 (1989), pp. 35-62, especialmente, p. 41.

21 Bogdandy, Armin von, "Pluralism, Direct Effect, and the Ultimate say: On the Relationship between International and Domestic Constitutional Law", International Journal of Constitutional Law, Vol. 6, num. 3-4 (2008), pp. 397-413. 
[s]i hasta el presente la teoría jurídica iuspositivista había padecido un exceso de concentración en un punto de gravitación único y jerárquico (Grundnorm), hacia el cual se hacían converger todos los procesos normativos, a partir del presente deberá acomodar su óptica de enfoque hacia unos ordenamientos jurídicos policéntricos. Por su parte, el profesor Neves ha propuesto una visión de la nueva realidad plural, que él esboza como un transconstitucionalismo, bajo la forma de un trapecio. ${ }^{22}$ Ya con anterioridad el profesor Tushnet había hablado de una visión constitucional transnacional. ${ }^{23}$ Desde la perspectiva de la articulación entre el derecho internacional y el derecho constitucional, el profesor Petersmann ha sostenido su versión de un sistema multilevel donde, por cierto, los derechos humanos como sistema de estándares mínimos, jugarían un rol fundamental en la solución frente a la concurrencia de normas. Petersmann ha sostenido, correctamente a nuestro entender, que, en general, mientras los Estados europeos han aceptado que la Convención Europea de Derechos Humanos y el derecho europeo comunitario han evolucionado hacia un derecho internacional Constitucional, el paradigma prevaleciente en muchos de los Estados fuera de Europa sigue siendo el nacionalismo constitucional en lugar de un "pluralismo constitucional multinivel. ${ }^{24}$

La nueva aproximación del derecho público hacia un orden plural, “impone sustituir la imagen piramidal, es decir, jerarquizada del orden normativo, por un horizonte en el que la totalidad del sistema se obtendrá por la intersección

22 Neves, Marcelo, Transconstitucionalismo, Sao Paulo, Wmf Martins Fontes, 2009, p. 115 et seq.

23 "This cross-fertilization between separate constitutional cultures, which appears to be in process, may create an important bridge toward the ultimate creation of a shared, transnational constitutional vision". Tushnet, Mark, "Transnational/Domestic Constitutional Law”, Loyola of Los Angeles Law Review, Vol. 37, issue 2, (Fall 2003), pp. 239-269.

24 "Historical experience confirms the constitutional claim that legal guarantees of equal freedoms among individuals and among republican states cannot remain effective over time without multilevel constitutionalism constituting, limiting and legitimizing governance powers and protecting human rights at national, international and transnational levels of human interactions in a mutually coherent manner". Petersmann, Ernst-Ulrich, "State Sovereignty, Popular Sovereignty and Individual Sovereignty: from Constitutional Nationalism to Multilevel Constitutionalism in International Economic Law?", EUI Working Papers, Law 2006/45. En: http://cadmus.eui.eu/dspace/bitstream/1814/6446/3/ LAW\%202006-45.pdf [consultado el 28 de noviembre de 2009]; Petersmann, Ernst-Ulrich, "Justice in International Economic Law? From the 'International Law among States' to 'International Integration law' and 'Constitutional Law'”, EUI Working Papers, Law No. 2006/46, http://cadmus.eui.eu/dspace/bitstream/1814/6447/1/LAW\%202006-46.pdf [consultado el 28 de noviembre de 2009]. 
de una pluralidad de estructuras normativas, de procedencia heterogénea y que hacinadas formarán un panorama del ordenamiento jurídico bastante parecido a una bóveda". ${ }^{25}$ En nuestra opinión, desde la perspectiva de los derechos humanos, tomando en consideración que los derechos humanos en cuanto tales irradian o se proyectan a todo el ordenamiento o a todos los ordenamientos de manera tal que determinan el comportamiento del referido ordenamiento en función de los principios rectores de los derechos humanos, la articulación de este orden jurídico plural debiera parecerse a un circulo. En este sistema jurídico singular, todos los órdenes jurídicos interactúan y la solución frente a la concurrencia de normas para resolver un caso debería encontrarse en principios, mecanismos o técnicas que permitieran este ajuste.

Por otra parte, dentro de las razones que se pueden aportar para justificar la conformación de este DADH se encuentran las siguientes:

En primer lugar, experiencias comunes: en la época de los años setenta y ochenta, los países del continente americano compartieron, en términos aproximados, las mismas experiencias de quiebre constitucional y democrático, con graves y sistemáticas violaciones a los derechos humanos.

En segundo lugar, procesos políticos y constitucionales similares. Como consecuencia de las experiencias vividas, las reacciones constitucionales y democráticas han sido, mutatis mutandis, las mismas o similares. En general, el patrón seguido en los países del continente fue el mismo. Por una parte, mantenimiento de las bases jurídicas establecidas por los regímenes autoritarios, por otra parte, dificultades para llevar adelante el procesamiento y juzgamiento de los responsables de las violaciones a los derechos humanos y, finalmente, apertura hacia un sistema regional de supervisión jurisdiccional de los derechos humanos.

En tercer lugar, proactividad y dinamismo del sistema interamericano de promoción y protección de los derechos humanos. Sin lugar a dudas que el sistema interamericano de promoción y protección de los derechos humanos se consolidó en la década de los años 90. Diversos Estados del continente aceptaron su jurisdicción obligatoria y enriquecieron su doctrina y jurisprudencia constitucional con las enseñanzas de la Corte IDH, órgano jurisdiccional internacional que se configura como el supremo intérprete regional en materia de derechos humanos. Este último es un patrón común, que se presenta con mayor o menor intensidad en los distintos países de

25 Pérez Luño, Antonio-Enrique, op. cit., nota 16, pp. 510-511. 
América Latina. Con todo, aun cuando este patrón se revele, en algunos Estados, ser de baja intensidad, es un hecho que las sentencias de la Corte IDH y sus enseñanzas y jurisprudencia están presentes en las experiencias constitucionales y en la jurisprudencia constitucional de los países de la región. ${ }^{26}$

26 Por ejemplo, para el caso Argentino, véase Simón, Julio Héctor y otros, Corte Suprema de Justicia de la Nación (CS) -2005-06-14, fallos: 328:2056; Para el caso de Perú, el Tribunal Constitucional ha señalado que "Para la resolución del caso es oportuno recordar que la Corte Interamericana de Derechos Humanos ha tenido oportunidad de condenar y sancionar a Estados que han ratificado la Convención Americana sobre Derechos Humanos por permitir que sus máximos órganos jurisdiccionales electorales se encuentren exentos de un control jurisdiccional frente a aquellas decisiones que contravengan los derechos fundamentales de las personas. En efecto, en el Caso Yatama vs. Nicaragua, la Corte Interamericana de Derechos Humanos sostuvo que : "Si bien la Constitución de Nicaragua ha establecido que las resoluciones del Consejo Supremo Electoral en materia electoral no son susceptibles de recursos ordinarios o extraordinarios, esto no significa que dicho Consejo no deba estar sometido a controles judiciales, como lo están los otros poderes del Estado. Las exigencias derivadas del principio de independencia de los poderes del Estado no son incompatibles con la necesidad de consagrar recursos o mecanismos para proteger los derechos humanos. Independientemente de la regulación que cada Estado haga respecto del órgano supremo electoral, éste debe estar sujeto a algún control jurisdiccional que permita determinar si sus actos han sido adoptados al amparo de los derechos y garantías mínimas previstos en la Convención Americana, así como los establecidos en su propia legislación, lo cual no es incompatible con el respeto a las funciones que son propias de dicho órgano en materia electoral. Este control es indispensable cuando los órganos supremos electorales, como el Consejo Supremo Electoral en Nicaragua, tienen amplias atribuciones, que exceden las facultades administrativas, y que podrían ser utilizados, sin un adecuado control, para favorecer determinados fines partidistas. En este ámbito, dicho recurso debe ser sencillo y rápido, tomando en cuenta las particularidades del procedimiento electoral. Por todo lo expuesto, la Corte concluye que el Estado violó el derecho a la protección judicial consagrado en el artículo 25.1 de la Convención Americana". Tribunal Constitucional de Perú: Caso Colegio de Abogados del Callao (demandante) c. Congreso de la República (demandado). Rol 00007-2007-PI/TC, Resolución del 19 de Junio de 2007; Para el caso de Chile, se ha indicado en el Informe entregado al Consejo de Derechos Humanos para el Examen Periódico Universal, que "De acuerdo a la reforma introducida al Art. 5 inciso 2 de la Constitución, ya mencionada, los derechos humanos establecidos en los tratados internacionales de derechos humanos tienen rango constitucional. Así se ha reconocido por los propios tribunales internos, los cuales han recurrido a la normativa internacional para fundamentar sus fallos. Cabe mencionar que la Corte Suprema ha citado el fallo de la Corte Interamericana de Derechos Humanos en el "Caso Almonacid", reafirmando que la prohibición de crímenes de lesa humanidad es una norma de ius cogens". Informe nacional de Chile presentado de conformidad con el párrafo 15 a) anexo a la resolución 5/1 del Consejo de Derechos Humanos. Doc. N.U. A/HRC/WG.6/5/CHL/1, del 16 de febrero de 2009, párrafo 18; véase Corte Suprema, 
Finalmente, como lo desarrollaremos en la segunda parte del presente artículo, creciente interacción y sinergia entre la Corte IDH y las instituciones constitucionales y democráticas de los Estados americanos. Luego de un inicio complejo en cuanto a la relación entre la Corte IDH y los Estados, hoy en día se puede argumentar que existe un verdadero diálogo entre la Corte IDH y sus enseñanzas y los órganos de los Estados, en particular, con la justicia ordinaria y constitucional, aunque muchas veces no muy fluido o desprovisto de obstáculos. Este diálogo entre el juez interamericano y el juez constitucional resulta singularmente relevante en la construcción coherente y uniforme de este verdadero corpus iuris interamericano que nosotros hemos denominado el DADH.

Además, este DADH tiene en sí mismo una virtualidad propia de los derechos humanos, cual es asegurar el principio democrático de no discriminación en el sentido que todos los individuos, grupos y pueblos de América, tendrían asegurado, al menos, un estándar básico de respeto y goce de los derechos humanos. En esta construcción del DADH, el derecho constitucional - del Estado democrático, multicultural y comunitario del tercer milenio- juega un rol clave.

\section{Principales características y elementos que lo componen}

Desde la perspectiva de los derechos humanos, existen una serie de características que nos permite avanzar una distinción entre el DADH y el derecho europeo de los derechos humanos (en adelante, el DEDH). Hasta ahora, el derecho africano de los derechos humanos y de los pueblos, nos permite menos comparación, sobre todo porque la Corte Africana de Derechos Humano y de los Pueblos (en adelante, la Corte ADH) solo ha entrado en funcionamiento recientemente. ${ }^{27}$

Secuestro calificado de Ricardo Troncoso Muñoz y otros. Causa Rol 3452-06, Sentencia del 10 de mayo de 2007.

27 El sistema africano de protección de los derechos humanos y de los pueblos se inserta en el contexto de la Unión Africana [ex Organización de la Unidad Africana]. Véase www.africa-union.org. Del mismo modo que el sistema americano, el sistema africano de protección de los derechos humanos y de los pueblos se compone de dos órganos principales. Por una parte, la Comisión Africana de Derechos Humanos y de los Pueblos, con sede en Banjul, Gambia. La Comisión Africana fue establecida, de una forma similar a la Comisión Interamericana de Derechos Humanos, en la Carta Africana de Derechos Humanos y de los Pueblos, de 1981, a partir del artículo 30 y siguientes. Véase $w w w$. 
En primer lugar, el DADH y el DEDH son dos corpus iuris que han nacido en contextos político-constitucionales diferentes y ello puede servir para explicar las vías de desarrollo que han seguido cada uno de ellos. En efecto, el DADH nació y se desarrolló, inicialmente, en un contexto donde ha existido un estado más o menos generalizado de regímenes autoritarios en el continente americano, en circunstancias que el DEDH nació en un contexto de Estados plenamente democráticos, comprometidos con el Estado de derecho y con la protección de los derechos humanos.

En segundo lugar, el DADH es un derecho más dinámico que el DEDH. Esta característica es tomada del propio funcionamiento del sistema. En efecto, el sistema interamericano y, en particular, la Corte IDH es más dinámica que la Corte Europea de Derechos Humanos, entendiendo por dinámica, la aplicación e interpretación menos tradicional y más avanzada de la Corte IDH, sobre todo, en ciertas materias claves para los derechos humanos. Como un ejemplo notable de estos desarrollos más dinámicos y diferenciados, se puede mencionar todo el desarrollo realizado por la Corte en torno al tema de las reparaciones a violaciones de los derechos humanos.

En tercer lugar, conectado con lo anterior, se encuentra el desarrollo que la Corte IDH ha efectuado de las normas de ius cogens, siendo recurrente, en este sentido, la referencia a las mismas. En especial, la Corte IDH ha innovadoramente desarrollado el principio de igualdad y la prohibición de la discriminación así como el derecho de acceso a la justicia como normas

achprorg. Por otra parte, la Corte Africana de Derechos Humanos y de los Pueblos, con sede en Arusha, Tanzania. Esta Corte fue creada por el Protocolo a la Carta Africana de Derechos Humanos y de los Pueblos sobre el establecimiento de una Corte Africana de Derechos Humanos y de los Pueblos, adoptado en Ouagadougou, Burkina Faso, en 1998 y entrado en vigor el año 2004. Hasta noviembre de 2009, 25 Estados africanos había ratificado el referido Protocolo de 1998. Los primeros 11 jueces de la Corte Africana de Derechos Humanos y de los Pueblos fueron elegidos el 22 de enero de 2006. El Consejo Ejecutivo de la Unión Africana en su $13^{\circ}$ sesión ordinaria de julio de 2008 reeligió algunos jueces y nombró dos nuevos jueces. En marzo de 2009, la Corte Africana de Derechos Humanos y de los Pueblos realizó las primeras audiencias sobre casos de violaciones a los derechos humanos. Véase www.african-court. org. Hoy en día existe el Protocolo sobre el Estatuto de la Corte Africana de Justicia y Derechos Humanos, adoptado en Sharm El-Sheikh (Egipto), en julio de 2008, que pretende fusionar la Corte Africana de Derechos Humanos y de los Pueblos con la Corte de Justicia de la Unión Africana (cuyo establecimiento se dispone en el Acta Constitutiva de la Unión Africana de 11 de julio de 2000 y regulada en el Protocolo de la Corte de Justicia de la Unión Africana de 11 de julio de 2003) y crear un único órgano denominado la Corte Africana de Justicia y Derechos Humanos. 
de ius cogens. La Corte EDH no ha realizado un reconocimiento tan avanzado como el de la Corte IDH.

En cuarto lugar, los derechos económicos, sociales y culturales contribuyen a darle identidad al trabajo de la Corte IDH y al DADH. Entendemos que la Corte EDH ha tenido la oportunidad de pronunciarse sobre los DESC, afirmando principios rectores cruciales para la teoría de estos derechos. ${ }^{28}$ Sin embargo, la Corte IDH ha ido paulatinamente avanzando y sentando su jurisprudencia sobre los DESC, sin pronunciarse expresamente y acogiendo una violación del artículo 26, único artículo que habla de DESC en la CADH. ${ }^{29}$ Además, resulta trascendental observar como la Corte IDH ha ido amparando de una cierta manera los DESC, por la vía de las reparaciones, técnica que, apareciendo como innovadora, permite afirmar que los DESC son justiciables, al igual que los derechos civiles y políticos. ${ }^{30}$ Muy probablemente, la Corte ADH tenderá a desarrollar también los DESC debido al sustento y arsenal normativo del que dispone dicha Corte según el Protocolo a la Carta Africana y debido a la realidad social concreta de los Estados que han aceptado la jurisdicción de la Corte ADH. En este contexto, resulta esclarecedor y, al mismo tiempo, esperanzador, el reciente fallo de la Corte de Justicia de la Comunidad Económica de los Estados de África Occidental (en adelante, la Corte de Justicia de la CEDEAO), del 19 de noviembre de 2009, en un caso contra el Estado de Nigeria, donde la Corte declaró que todos los nigerianos tenían el derecho a la educación como un derecho legal y humano. En este landmark case, la Corte de Justicia de la CEDEAO afirma sin ambages la justiciabilidad de los DESC, en particular, del derecho a la educación. En efecto, la Corte de Justicia declaró que "se encuentra bien establecido que los derechos garantizados por la Carta Africana son justiciables ante esta Corte. Por lo tanto, desde el momento

28 Delzangles, Béatrice, "L'émergence des droits et objectifs sociaux dans le contentieux européen des droits de l'homme”, L'Observateur des Nations Unies, 17 (2004), pp. 1-23.

29 “Artículo 26. Desarrollo Progresivo: Los Estados partes se comprometen a adoptar providencias, tanto a nivel interno como mediante la cooperación internacional, especialmente económica y técnica, para lograr progresivamente la plena efectividad de los derechos que se derivan de las normas económicas, sociales y sobre educación, ciencia y cultura, contenidas en la Carta de la Organización de los Estados Americanos, reformada por el Protocolo de Buenos Aires, en la medida de los recursos disponibles, por vía legislativa u otros medios apropiados". Convención Americana sobre Derechos Humanos.

30 Véase Feria Tinta, Mónica, "Justiciability of Economic, Social and Cultural Rights in the Inter-American System of Protection of Human Rights: Beyond Traditional Paradigms and Notions", Human Rights Quarterly, vol. 29 (2007), pp. 431-459. 
en que la demanda de SERAP ha sido interpuesto de acuerdo a un derecho garantizado por las disposiciones de la Carta Africana, el argumento del gobierno de que el derecho a la educación no es justiciable ya que cae dentro de los principios directivos de la política estatal, no puede ser admitido". ${ }^{31}$

Finalmente, otro elemento característico del DADH es la presencia de la diversidad cultural y su protección jurídica, y del derecho a la identidad cultural, en su dimensión individual y, particularmente, colectiva. Este elemento se encuentra fuertemente presente en el DADH, más no así en el DEDH. Más cercano al DADH es el Derecho africano de los derechos humanos y de los pueblos cuyo sustento normativo principal, a saber, la Carta Africana de Derechos Humanos y de los Pueblos (también llamada Carta de Banjul, del 27 de julio de 1981), ya nos adelanta una tendencia al reconocimiento de la diversidad cultural y de los derechos colectivos. ${ }^{32}$

De este modo, el DADH posee una normativa determinada, una comunidad de destinatarios definida y órganos (cuasi-jurisdiccionales y jurisdiccionales) de supervisión y control, lo cual modela y confirma la existencia de este corpus iuris.

Desde el punto de vista de la normativa que lo compone, se pueden mencionar los instrumentos regionales de derechos humanos, empezando por

31 Además, en este caso, la Corte afirmó el principio de Derecho Internacional de la actio popularis en casos de violaciones a los derechos humanos, cuando señaló que "Public International Law in general is in favour of promoting human rights and limiting the impediments against such a promotion, lends credence to the view that in public interest litigation, the plaintiff need not show that he has suffered any personal injury or has a special interest that needs to be protected to have standing. Plaintiff must establish that there is a public right which is worthy of protection which has been allegedly breached and that the matter in question is justiciable. This is a healthy development in the promotion of human rights and this court must lend its weight to it, in order to satisfy the aspiration of citizens of the sub-region in their quest for a pervasive human rights regimee". ECOWAS, Landmark Court Decision on Right to Education, www.crin.org/resources/ infoDetail.asp? ID=21322 [consultado el 24 de noviembre de 2009].

32 La Carta Africana sobre los Derechos Humanos y de los Pueblos reconoce expresamente en sus artículos 19 a 24, como el nombre del Convenio lo indica, derechos de los pueblos, aunque sin mencionar explícitamente a los pueblos indígenas. Además, la Carta de Banjul efectúa un reconocimiento de la identidad cultural y de la diversidad étnica cuando se refiere al derecho de los individuos "a participar libremente en la vida cultural de su comunidad" y cuando establece como deber del Estado promover y proteger "la moral y los valores tradicionales reconocidos por la comunidad" (artículo 17). 
la Carta de la Organización de Estados Americanos (en adelante, la OEA) en cuyo preámbulo se señala que los pueblos de América están

[s] eguros de que el sentido genuino de la solidaridad americana y de la buena vecindad no puede ser otro que el de consolidar en este Continente, dentro del marco de las instituciones democráticas, un régimen de libertad individual y de justicia social, fundado en el respeto de los derechos esenciales del hombre". ${ }^{33}$ Además, por supuesto, la Convención Americana sobre Derechos Humanos (también llamada Pacto de San José), complementada con el Protocolo de San Salvador y otros instrumentos jurídicos regionales. ${ }^{34} \mathrm{~A}$ estos instrumentos vinculantes, hay que sumar otros no vinculantes - al menos en cuanto tales - tales como la Declaración Americana de Derechos y Deberes del Hombre (en adelante, la DADDH), cuyo preámbulo ya en 1948, adelantaba el surgimiento, en cierne, de este DADH, al señalar que "la protección internacional de los derechos del hombre debe ser guía principalísima del derecho americano en evolución. ${ }^{35}$

Luego, desde la perspectiva de la comunidad a la que rige, el DADH tiene como destinatario general todos los individuos, grupos y pueblos que se encuentren dentro de la jurisdicción de los Estados miembros de la OEA.

33 Preámbulo de la Carta de la Organización de los Estados Americanos, suscrita en Bogotá en 1948 y reformada por el Protocolo de Buenos Aires en 1967, por el Protocolo de Cartagena de indias en 1985, por el Protocolo de Washington en 1992, y por el Protocolo de Managua en 1993.

34 Véase Protocolo a la Convención Americana sobre Derechos Humanos relativo a la abolición de la pena de muerte. (Aprobado en Asunción, Paraguay, el 8 de junio de 1990); Convención Interamericana para Prevenir y Sancionar la Tortura (Adoptada en Cartagena de Indias, Colombia, el 9 de diciembre de 1985 en el decimoquinto período ordinario de sesiones de la Asamblea General); Convención Interamericana sobre Desaparición Forzada de Personas (Adoptada en Belém do Pará, Brasil, el 9 de junio de 1994, en el vigésimo cuarto período ordinario de sesiones de la Asamblea General); Convención Interamericana para Prevenir, Sancionar y Erradicar la Violencia contra la Mujer "Convención de Belém do Pará" (Adoptada en Belém do Pará, Brasil, el 9 de junio de 1994, en el vigésimo cuarto período ordinario de sesiones de la Asamblea General); Convención Interamericana para la Eliminación de todas las formas de Discriminación contra las personas con Discapacidad (Adoptada en Ciudad de Guatemala, Guatemala el 7 de junio de 1999, en el vigésimo noveno período ordinario de sesiones de la Asamblea General); y Carta Democrática Interamericana (Aprobada en la primera sesión plenaria, celebrada el 11 de septiembre de 2001).

35 Preámbulo de la Declaración Americana de los Derechos y Deberes del Hombre (aprobada en la Novena Conferencia Internacional Americana), Bogotá, Colombia, 1948. 
Finalmente, desde la óptica de los órganos de supervisión (jurisdiccionales y cuasi-jurisdiccionales), los derechos humanos en el continente son supervisados por dos órganos internacionales. En primer lugar, por la Comisión Interamericana de Derechos Humanos (en adelante, la CIDH), que posee competencia para conocer de las denuncias de particulares respecto de Estados miembros de la OEA y la Corte Interamericana de Derechos Humanos que posee competencia contenciosa para conocer de demandas presentadas por la propia Comisión o por los Estados partes contra otros Estados que han aceptado expresamente su jurisdicción. ${ }^{36}$

En consecuencia, se puede observar el surgimiento de un DADH, cuyas características, en términos muy generales, se podrían esbozar en las siguientes: a) se trata de un Derecho de origen internacional, pero en el cual se puede ver reflejada la confluencia entre estándares del derecho internacional y principios básicos del derecho constitucional de los Derechos Humanos; b) se trata de un derecho dinámico, en permanente creación y evolución. Tal como lo ha sostenido el juez Cançado Trindade, "al fin y al cabo, tarde o temprano, aún frente a los más crueles crímenes de Estado, el derecho reacciona", ${ }^{37}$ sobre todo el DADH, por su carácter esencialmente vivo y dinámico, aportando protección, reconocimiento y reparación al ser humano; c) el DADH configura un derecho cuyo fin natural es penetrar e incorporarse en los órdenes jurídicos internos por la vía del derecho constitucional de los Estados; d) por esta vía de recepción natural, el DADH debiera tender a uniformar los contenidos y la aplicación de los derechos humanos en los diversos órdenes constitucionales americanos, el cual se

36 Sobre la competencia de la Comisión: “Artículo 44: Cualquier persona o grupo de personas, o entidad no gubernamental legalmente reconocida en uno o más Estados miembros de la Organización, puede presentar a la Comisión peticiones que contengan denuncias o quejas de violación de esta Convención por un Estado parte". Convención Americana sobre Derechos Humanos de 1969; Sobre la competencia de la Corte: "Artículo 62: 1. Todo Estado parte puede, en el momento del depósito de su instrumento de ratificación o adhesión de esta Convención, o en cualquier momento posterior, declarar que reconoce como obligatoria de pleno derecho y sin convención especial, la competencia de la Corte sobre todos los casos relativos a la interpretación o aplicación de esta Convención". Convención Americana sobre Derechos Humanos de 1969.

37 Corte IDH, Caso Goiburú y otros vs. Paraguay, Fondo, Reparaciones y Costas, Sentencia del 22 de septiembre de 2006, Serie C, núm. 153, Voto razonado del juez A. A. Cançado Trindade, párrafo 68, p. 23. 
configuraría como el estándar mínimo en materia de derechos humanos exigible a los Estados del Continente. ${ }^{38}$

Por otra parte, esta suerte de umbral mínimo de derechos humanos, que el DADH, por la vía del derecho constitucional de los Estados, tiende a asegurar a todos los individuos y grupos de la región, permitiría resolver las chocantes diferencias y discriminaciones que se presentan hoy en día tanto a nivel intraestatal como a nivel extraestatal.

A nivel intraestatal, el estándar mínimo asegura un respeto homogéneo elemental de todos los derechos humanos, esto es, civiles y políticos y además, económicos, sociales y culturales, respecto de todas las capas de la sociedad. De esta manera, en términos de derechos, se reduciría aunque no se eliminaría, la abismante diferencia de desarrollo humano entre las capas de la sociedad, y este último, sería un avance en relación con elevados índices de igualdad y combate a la discriminación, ya que estaría asegurado, al menos, el acceso igualitario de todos a este umbral mínimo.

Al mismo tiempo, a nivel extraestatal, la gestación de este DADH entendido como estándar mínimo de los derechos humanos, lo que a su vez implicaría, una concepción elemental comúnmente compartida de los derechos del hombre en América, estimula una suerte de justicia (constitucional) comunitaria, entre los Estados del continente, equiparando o nivelando la situación de sus miembros, individuos y grupos, en términos de derechos humanos, descartando, asimismo, las odiosas diferencias de derechos y, consecuentemente, de desarrollo humano, actualmente persistentes entre las sociedades de América Latina. En este sentido, como ha señalado Solozabal Echavarría, "en la medida en que los derechos fundamentales definen el

38 Comparativamente hablando en relación con el sistema europeo de derechos humanos, la Corte Europea de Derechos Humanos, argumentando respecto de la Carta de Derechos Fundamentales de la Unión Europea, ha afirmado que pese a no ser plenamente vinculante, las disposiciones de la Carta se inspiraron esencialmente en las del Convenio Europeo de Derechos Humanos, reconociendo aquella que éste establece estándares mínimos de derechos humanos. "Although not fully binding, the provisions of the Charter of Fundamental Rights of the European Union were substantially inspired by those of the Convention, and the Charter recognises the Convention as establishing the minimum human rights standards". ECHR, Case of Bosphorus Hava Yollari Turizm Ve Ticaret Anonim Sirketi vs. Ireland (Application no. 45036/98), Judgment, 30 June 2005, párrafo 156; Alonso García, Ricardo y Sarmiento, Daniel, La Carta de los Derechos Fundamentales de la Unión Europea, Navarra, Thomson-Civitas, 2006, p. 47. 
status jurídico básico del individuo, actúan como un factor de homogeneización de todo el sistema jurídico". ${ }^{39}$

En suma, el DADH se encontraría compuesto de las tradiciones constitucionales comunes de los Estados del continente y de los instrumentos internacionales de derechos humanos que obligan a los Estados de la región, particularmente, la CADH, y, además, la Declaración Americana de Derechos y Deberes del Hombre de 1948.

\section{A. Hacia la concretización de tradiciones constitucionales comunes de los Estados de América Latina}

El preámbulo de la Declaración Americana de Derechos y Deberes del Hombre, de 1948, deja entrever que este DADH se forja en la confluencia mutuamente enriquecedora entre la protección internacional y las tradiciones constitucionales nacionales comunes, al señalar que

los pueblos americanos han dignificado la persona humana y que sus Constituciones nacionales reconocen que las instituciones jurídicas y políticas, rectoras de la vida en sociedad, tienen como fin principal la protección de los derechos esenciales del hombre y la creación de circunstancias que le permitan progresar espiritual y materialmente y alcanzar la felicidad. ${ }^{40}$

A este enriquecimiento mutuo - que acerca los procesos constitucionales en materia de derechos fundamentales - se refiere Corchete Martín cuando señala que por medio de los tratados internacionales de derechos humanos "se produce, dentro de los Estados firmantes, una especie de proceso de integración a un ámbito superior, en este caso, en materia de derechos fundamentales, que permite enriquecer las perspectivas nacionales a través, entre otros mecanismos, de la experiencia foránea" ${ }^{41}$ Del mismo modo, tal como señala Zarini, "está reconocido universalmente que los derechos esenciales del hombre no nacen del hecho de ser nacional de determinado

39 Solozábal Echavarría, Juan José, “Algunas cuestiones básicas de la teoría de los derechos fundamentales”, Revista de Estudios Politicos (Nueva Época), núm. 71, eneromarzo 1991, pp. 87-109, especialmente, p. 88.

40 Preámbulo de la Declaración Americana de los Derechos y Deberes del Hombre (aprobada en la Novena Conferencia Internacional Americana), Bogotá, Colombia, 1948.

41 Corchete Martín, María José, "Los nuevos derechos", Teoría y Realidad Constitucional, núm. 20 (2007), pp. 535-556, especialmente, p. 554. 
Estado, sino que se basan en los atributos inherentes a la persona humana, por lo que se justifica una protección internacional, de "naturaleza convencional coadyuvante o complementaria de la que ofrece el derecho interno de los Estados americanos', como establece el Preámbulo de la Convención Americana sobre Derechos Humanos". 42

El estándar mínimo americano, determinado por el sistema interamericano de promoción y protección de los derechos humanos, y, en particular, por la actividad de la Corte IDH e integrado, además, por las tradiciones constitucionales comunes de los Estados, debiera incorporarse en las Constituciones de los Estados americanos, configurando, a su vez, el estándar constitucional mínimo en materia de derechos humanos del constitucionalismo democrático y comunitario americano del tercer milenio. Así, parafraseando a Rawls, esta concepción común de la justicia de los derechos humanos constituiría la base del modelo de democracia constitucional americana. ${ }^{43}$

Tomando en cuenta que el ordenamiento del DADH tiene su origen en los instrumentos internacionales de derechos humanos, particularmente, en la Declaración Americana de Derechos y Deberes del Hombre y en la Convención Americana sobre Derechos Humanos, y en las tradiciones constitucionales comunes de los Estados latinoamericanos, el contenido de este orden de los derechos humanos se incardina en una cultura de los derechos humanos que no es desconocida en la región ni en ninguno de los Estados constitucionales latinoamericanos. ${ }^{44}$

En el ámbito de la existencia de principios comunes, compartidos por los Estados americanos, la Corte IDH ha resaltado un ejemplo patente en el Caso de las Hermanas Serrano Cruz. En efecto, a propósito del crimen de desaparición forzada de personas, la Corte afirmó que dicho crimen

significa un craso abandono de los valores que emanan de la dignidad humana $\mathrm{y}$ de los principios esenciales en que se fundamentan el sistema interamericano y la propia Convención Americana. Igualmente claro es el hecho que este delito implica un conjunto de violaciones a diferentes derechos consagrados en la Convención y que para declarar la violación de tales derechos el Tri-

${ }^{42}$ Zarini, Helio Juan, Derecho constitucional, 2a. ed., Buenos Aires, Astrea, 1999, p. 435.

${ }^{43}$ Rawls, John, Teoría de la justicia, Trad. de María Dolores González Soler, Ed. Fondo de Cultura Económica, México, Segunda Edición, 1995, p. 229.

${ }^{44}$ Para un enfoque centrado en Europa, véase Alonso García, Ricardo y Sarmiento, Daniel, op. cit., nota 39, p. 27. 
bunal no requiere que el Estado demandado haya ratificado la Convención Interamericana sobre la materia, así como tampoco lo requiere para calificar al conjunto de violaciones como desaparición forzada. ${ }^{45}$

Este principio esencial en que se fundamenta el sistema interamericano, fue reiterado como tal, en el caso Heliodoro Portugal vs. Panamá, de 2008. ${ }^{46}$

Sin embargo, en nuestro concepto, el esfuerzo más claro que ha efectuado la Corte IDH por mostrar que realmente existe un DADH, se puede apreciar en el caso Anzualdo Castro vs. Perú, de 2009. En efecto, en dicho caso, la Corte funda su consideración sobre la desaparición forzada de personas como un principio esencial del sistema interamericano, además, en las decisiones judiciales internas de diversos Estados americanos, particularmente, en las decisiones de diversas Cortes Constitucionales americanas. ${ }^{47}$

Así, se puede afirmar la existencia de un parámetro americano de protección de los derechos humanos, común a todos los Estados americanos, proveniente de las tradiciones constitucionales comunes y de los instrumentos internacionales de derechos humanos que los vinculan, particularmente, la DADDH y la CADH, y establecido en forma viviente día a día por medio de la actividad jurisprudencial de la Corte IDH. ${ }^{48}$

45 Corte IDH, Caso de las Hermanas Serrano Cruz vs. El Salvador, Excepciones Preliminares, Sentencia del 23 de noviembre de 2004, Serie C, núm. 118, párrafo 105, p. 35. El destacado es nuestro.

${ }^{46}$ Corte IDH, Caso Heliodoro Portugal vs. Panamá, Excepciones Preliminares, Fondo, Reparaciones y Costas, Sentencia del 12 de agosto de 2008, Serie C, núm. 186, párrafo 118 , p. 33.

47 "La jurisprudencia de órganos de Naciones Unidas, así como del Sistema Europeo de Derechos Humanos, coincide con esta caracterización, al igual que varias Cortes Constitucionales de los Estados americanos. En sentido similar se han pronunciado tribunales nacionales del Estado demandado, por ejemplo, la Sala Penal Nacional del Perú. Además, en razón de la naturaleza misma de la desaparición forzada, mediante la cual se somete a la víctima a una situación agravada de vulnerabilidad, surge el riesgo de que se violen diversos derechos, lo cual se evidencia en mayor medida cuando se está frente a un patrón sistemático de violaciones de derechos humanos". Corte IDH, Caso Anzualdo Castro vs. Perú, Excepción Preliminar, Fondo, Reparaciones y Costas, Sentencia del 22 de Septiembre de 2009, Serie C, núm. 202, párrafo 61, p. 22.

48 González González, Rossana, "Límites a la construcción de un “orden público europeo" en materia de derechos fundamentales (A propósito de la sentencia del TJCE Krombach c. Bamberski, de 28 de marzo de 2000)", Revista de Derecho Comunitario Europeo, núm. 8, julio-diciembre 2000, pp. 593-617, especialmente, p. 614. 
En este ámbito, los derechos fundamentales juegan un rol esencial de uniformación y homogeneización de los estándares de vida y condiciones de vida digna de los seres humanos del continente americano. ${ }^{49}$

\section{B. Los instrumentos internacionales de derechos humanos, especialmente, la CADH}

En las últimas décadas, se ha apreciado un notable aumento en la cantidad de ratificaciones de instrumentos internacionales en los países de América Latina, lo cual corresponde a la dinámica propia de la comunidad internacional en el período posterior a la caída del Muro de Berlín donde también se aprecia, a nivel mundial, un aumento en la ratificación de instrumentos

49 "El derecho a la vida es un derecho humano fundamental, cuyo goce es un prerrequisito para el disfrute de todos los demás derechos humanos. De no ser respetado, todos los derechos carecen de sentido. En razón del carácter fundamental del derecho a la vida, no son admisibles enfoques restrictivos del mismo. En esencia, el derecho fundamental a la vida comprende, no sólo el derecho de todo ser humano de no ser privado de la vida arbitrariamente, sino también el derecho a que no se le impida el acceso a las condiciones que le garanticen una existencia digna. Los Estados tienen la obligación de garantizar la creación de las condiciones que se requieran para que no se produzcan violaciones de ese derecho básico y, en particular, el deber de impedir que sus agentes atenten contra él". Corte IDH, Caso de los "Niños de la Calle" (Villagrán Morales y otros) Vs. Guatemala, Fondo, Sentencia del 19 de noviembre de 1999, Serie C, núm. 63, párrafo 144, p. 40; "Nuestra concepción del derecho a la vida bajo la Convención Americana (artículo 4, en conexión con el artículo 1.1) es manifestación de esta interpretación evolutiva de la normativa internacional de protección de los derechos del ser humano. En los últimos años, se han deteriorado notoriamente las condiciones de vida de amplios segmentos de la población de los Estados Partes en la Convención Americana, y una interpretación del derecho a la vida no puede hacer abstracción de esta realidad, sobre todo cuando se trata de los niños en situación de riesgo en las calles de nuestros países de América Latina". Corte IDH, Caso de los "Niños de la Calle" (Villagrán Morales y otros) vs. Guatemala, Fondo, Sentencia del 19 de noviembre de 1999, Serie C, núm. 63, Voto concurrente conjunto de los jueces A. A. Cançado Trindade y A. Abreu Burelli, párrafo 6, p. 2; "Una de las obligaciones que ineludiblemente debe asumir el Estado en su posición de garante, con el objetivo de proteger y garantizar el derecho a la vida, es la de generar las condiciones de vida mínimas compatibles con la dignidad de la persona humana203 y a no producir condiciones que la dificulten o impidan. En este sentido, el Estado tiene el deber de adoptar medidas positivas, concretas y orientadas a la satisfacción del derecho a una vida digna, en especial cuando se trata de personas en situación de vulnerabilidad y riesgo, cuya atención se vuelve prioritaria”. Corte IDH, Caso Comunidad Indigena Yakye Axa vs. Paraguay, Fondo Reparaciones y Costas, Sentencia 17 de junio de 2005, Serie C, núm. 125 , párrafo 162 , p. 88 . 
internacionales. En este sentido, quizás vale la pena agregar que también se observa un incremento sostenido en el debate y producción normativa internacional, ya sea por medio de la realización de conferencias internacionales especializadas o cumbres regionales o internacionales de Estados.

Esta mayor producción y suscripción de instrumentos internacionales de derechos humanos se ve complementada con un incremento del proceso de incorporación estatal de los instrumentos internacionales de derechos humanos, asignándoles en forma creciente el rango constitucional. Esta confluencia entre DIDH y derecho constitucional de los derechos humanos se produce justamente porque ambos órdenes reflejan la regulación de los derechos que emanan de la dignidad humana. ${ }^{50}$ En este sentido, Corchete Martín, ha señalado que, en definitiva, "el derecho internacional vendría a completar al derecho interno, tratando de crear un marco común en esta materia [derechos fundamentales] de claro carácter internacional". ${ }^{51}$

En consecuencia, necesariamente, tanto el orden internacional como el orden constitucional de los derechos humanos, comparten rasgos comunes. En palabras del profesor Pérez Luño, refiriéndose a la Constitución Española, "se desprende de la CE que nuestros derechos fundamentales constituyen un sistema de valores objetivos dotados de una unidad de sentido y que representan la suprema expresión del orden axiológico de nuestra sociedad, así como también de la comunidad internacional a la que pertenecemos". ${ }^{52}$

Por otro lado, los países de América Latina han reiterado en diversas ocasiones su compromiso inequívoco por los derechos humanos y por el respeto y apego irrestricto al derecho internacional. Así, por ejemplo, en la Quinta Cumbre de las Américas de 2009, los Estados del continente reiteraron su "compromiso para proteger y promover los derechos humanos en nuestro Hemisferio, y el fortalecimiento del sistema interamericano de derechos humanos, con debido respeto a su autonomía e independencia. Expresamos nuestra voluntad de continuar profundizando el diálogo constructivo con la participación de todos sus actores, incluyendo la Comisión Interamericana de Derechos Humanos y la Corte Interamericana de Derechos Humanos, en el marco del proceso de reflexión que contribuye al perfeccionamiento,

50 Véase cómo el profesor Ortega Santiago habla de un derecho constitucional de los derechos fundamentales. Ortega Santiago, Carlos, "Las nuevas fronteras de los derechos fundamentales en el ordenamiento italiano: crónica de un lento avance", Teoría y Realidad Constitucional, núm. 20, 2007, pp. 569-582.

51 Corchete Martín, María José, op. cit., nota 42, p. 556.

52 Pérez Luño, Antonio-Enrique, op. cit., nota 10, p. 500. 
eficacia, universalización y el adecuado financiamiento de los órganos del sistema". 53

Anteriormente, en la Cumbre de San Salvador (2008), los jefes de Estado y de gobierno reiteraron su "compromiso con los principios y propósitos reconocidos en la Carta de Naciones Unidas, los valores esenciales de la democracia, la promoción y el respeto de todos los derechos humanos, el fortalecimiento del multilateralismo, el combate al terrorismo y a la delincuencia transnacional organizada y el rechazo a las medidas coercitivas unilaterales, contrarias al derecho internacional, los cuales constituyen pilares fundamentales para que las y los jóvenes contribuyan como sujetos activos a la construcción de sociedades basadas en la justicia social, la tolerancia y la convivencia pacífica". ${ }^{54}$

Por su parte, en la Declaración de Santiago (2007), los jefes de Estado y de gobierno ya habían efectuado el compromiso de trabajar por la cohesión social mediante el respeto de los derechos humanos, cuando señalaron que se comprometen a "colaborar estrechamente para colocar en el núcleo central de la agenda internacional el interés por la cohesión social y la necesidad de alcanzar sociedades más inclusivas con pleno respeto a los derechos humanos, así como la promoción de un entorno internacional favorable a los esfuerzos nacionales e internacionales en materia de protección social y políticas para la superación de la pobreza, la desigualdad y el hambre en el mundo y el cumplimiento de los Objetivos de Desarrollo del Milenio". ${ }^{55}$

En forma reiterada, las Constituciones de América han ido incorporando diversas referencias al DIDH, aun cuando, estas referencias son desiguales o asimétricas entre un Estado y otro. La mayoría de las Constituciones sólo hace esta referencia, restringiéndola a los instrumentos internacionales de derechos humanos, como si los derechos humanos sólo se redujeran a la

53 Véase Declaración de Compromiso de Puerto España, Quinta Cumbre de las Américas, realizada del 17 al 19 de abril de 2009, en Puerto España, Trinidad y Tobago, párrafo 83.

54 Véase Declaración de San Salvador "Juventud y Desarrollo", efectuada con ocasión de la XVIII Cumbre Iberoamericana de Jefes de Estado y de Gobierno, realizada en la ciudad de San Salvador, República de El Salvador, el 29, 31 de octubre de 2008, párrafo 4.

55 Además, la Declaración de Santiago agrega: "Fortalecer la promoción y respeto de todos los derechos humanos como un componente indispensable en la adopción y ejecución de las políticas destinadas a lograr la cohesión social». Véase Declaración de Santiago, efectuada en la XVII Cumbre Iberoamericana de Jefes de Estado y de Gobierno, realizada en Chile, 8, 9 y 10 de noviembre de 2007, pars. 3 y 13. 
fuente convencional. Esta mirada de la Constitución, cada vez más intensa, hacia el orden internacional, contiene la reflexión de que "[1]a idea de Constitución deja el horizonte nacional atrás, avanza más allá hacia campos supraestatales". ${ }^{66}$

La importancia que han adquirido los derechos humanos en el constitucionalismo de las últimas tres décadas en América, queda en evidencia por medio de los debates y de las reformas constitucionales que han generado. De igual modo, en algunos casos, las Constituciones no se han contentado con referirse a los instrumentos internacionales de derechos humanos, sino que además han hecho referencia a la jerarquía normativa que en el orden interno poseen dichos instrumentos.

Por ejemplo, en la Constitución argentina se señala que

[1]a Declaración Americana de los Derechos y Deberes del Hombre; la Declaración Universal de Derechos Humanos; la Convención Americana sobre Derechos Humanos; el Pacto Internacional de Derechos Económicos, Sociales y Culturales; el Pacto Internacional de Derechos Civiles y Políticos y su Protocolo Facultativo; la Convención sobre la Prevención y la Sanción del Delito de Genocidio; la Convención Internacional sobre la Eliminación de todas las Formas de Discriminación Racial; la Convención sobre la Eliminación de todas las Formas de Discriminación contra la Mujer; la Convención contra la Tortura y otros Tratos o Penas Crueles, Inhumanos o Degradantes; la Convención sobre los Derechos del Niño: en las condiciones de su vigencia, tienen jerarquía constitucional, no derogan artículo alguno de la primera parte de esta Constitución y deben entenderse complementarios de los derechos y garantías por ella reconocidos. Solo podrán ser denunciados, en su caso, por el Poder Ejecutivo nacional, previa aprobación de las dos terceras partes de la totalidad de los miembros de cada Cámara. Los demás tratados y convenciones sobre derechos humanos, luego de ser aprobados por el Congreso, requerirán del voto de las dos terceras partes de la totalidad de los miembros de cada Cámara para gozar de la jerarquía constitucional. ${ }^{57}$

Y, por su parte, en la Constitución de Venezuela, se señala que

[1]os tratados, pactos y convenciones relativos a derechos humanos, suscritos y ratificados por Venezuela, tienen jerarquía constitucional y prevalecen en el orden interno, en la medida en que contengan normas sobre su goce

56 Biaggini, Giovanni, op. cit., nota 6, p. 47.

57 Artículo 75, Constitución de la República de Argentina, 1994. 
y ejercicio más favorables a las establecidas por esta Constitución y la ley de la República, y son de aplicación inmediata y directa por los tribunales y demás órganos del Poder Público. ${ }^{58}$

En términos generales, actualmente, existe la tendencia a asignarles rango constitucional..$^{59}$

\section{El orden público y el espacio público americano}

Un orden público americano sería aquel que en el contexto regional mencionado determina ciertos principios, estándares, reglas y valores mínimos que apuntan a preservar al individuo y a permitir su pleno desenvolvimiento material y espiritual en el seno de la sociedad, limitando, de esta manera, el poder de los Estados y, además, de los individuos, grupos y otros actores no estatales. Este orden público americano, consagra un Estado de derecho global o internacional (o al menos americano), asegurando la libertad del individuo en un contexto de respeto hacia la comunidad y establece los límites infranqueables del poder vis-à-vis la existencia y los derechos del individuo, de los grupos y de los pueblos. ${ }^{60}$ En este sentido, la Corte IDH ha proporcio-

58 Artículo 23, Constitución de la República Bolivariana de Venezuela, 1999.

59 Un ejemplo de esta fuerte tendencia se puede encontrar en el ámbito europeo, en la Constitución del Principado de Andorra de 1993. "Alors qu'il faut recourir au Préambule de la Constitution française pour trouver une assise juridique aux droits de l'homme en France, la Constitution de la Principauté d'Andorre consacre un chapitre entier à ces principes supérieurs que sont les droits fondamentaux" "[...] la Constitution andorrane ne se contente pas de décrire et de conférer ainsi directement une valeur constitutionnelle á ces principes [...]". Lacamp-Leplaë, Odile, "La sauvegarde des droits fondamentaux en Andorre”, Revue Internationale de Droit Comparé, vol. 53, núm. 2 (2001), pp. 483-493, especialmente, p. 485.

${ }^{60}$ Una de las reglas básicas de este Estado de derecho internacional o supranacional — la limitación del poder estatal — ha sido establecida y repetida en reiteradas ocasiones por la Corte IDH, a saber, "[...] no cabe admitir que el poder pueda ejercerse sin límite alguno o que el Estado pueda valerse de cualquier procedimiento para alcanzar sus objetivos, sin sujeción al derecho o a la moral. Ninguna actividad del Estado puede fundarse sobre el desprecio a la dignidad humana". Véase Corte IDH, Caso Velásquez Rodríguez vs. Honduras, Fondo. Sentencia del 29 de julio de 1988, Serie C, núm. 4, párrafo 154, p. 32. Esta regla básica esta complementada por la obligación general del Estado de garantizar los derechos humanos. En efecto, esta Corte ha señalado que "[e]sta obligación implica el deber de los Estados Parte de organizar todo el aparato gubernamental y, en general, todas las estructuras a través de las cuales se manifiesta el ejercicio del poder público, de manera tal que sean capaces de asegurar jurídicamente el libre y pleno ejercicio 
nado una especie de conceptualización del orden público que tiene su base en la CADH, y que ella califica de orden público democrático. En su Opinión Consultiva sobre La Colegiación Obligatoria de Periodistas, señaló que

[n]o escapa a la Corte, sin embargo, la dificultad de precisar de modo unívoco los conceptos de "orden público" y "bien común", ni que ambos conceptos pueden ser usados tanto para afirmar los derechos de la persona frente al poder público, como para justificar limitaciones a esos derechos en nombre de los intereses colectivos. A este respecto debe subrayarse que de ninguna manera podrían invocarse el "orden público" o el "bien común" como medios para suprimir un derecho garantizado por la Convención o para desnaturalizarlo o privarlo de contenido real. ${ }^{61}$

Cançado Trindade, por su parte, ha reforzado esta idea de orden público cuando en su voto disidente en la sentencia sobre excepciones preliminares en el caso de las Hermanas Serrano Cruz, señaló que:

la primacía de consideraciones de ordre public sobre la voluntad de Estados individuales, han establecido estándares más altos de comportamiento estatal y cierto grado de control sobre la interposición de restricciones indebidas por parte de los Estados, y han, de modo alentador, fortalecido la posición de los individuos como sujetos del DIDH, con plena capacidad procesal. ${ }^{62}$

Esta noción de orden público, se ve respaldada también por decisiones transatlánticas, en este caso, de la Corte de Justicia de la Comunidad CE$\mathrm{DEAO}$, en donde, a propósito de la esclavitud, dicha Corte ha declarado que el Estado debe proteger a las personas de las situaciones de esclavitud y que, en consecuencia, el Estado es responsable tanto en derecho internacional como nacional de toda forma de violación de los derechos humanos de la demandante fundada en la esclavitud, debido a la tolerancia, la pasividad,

de los derechos humanos". Véase Corte IDH, Caso Anzualdo Castro vs. Perú, Excepción Preliminar, Fondo, Reparaciones y Costas, Sentencia del 22 de septiembre de 2009, Serie C, núm. 202, párrafo 62, p. 22.

61 Corte IDH, La Colegiación Obligatoria de Periodistas (Arts. 13 y 29 Convención Americana sobre Derechos Humanos), Opinión Consultiva OC-5/85 del 13 de noviembre de 1985, Serie A No. 5, párrafo 66, p. 20.

62 Corte IDH, Caso de las Hermanas Serrano Cruz vs. El Salvador, Excepciones Preliminares, Sentencia del 23 de noviembre de 2004, Serie C, núm. 118, Voto Disidente del juez Antonio Augusto Cançado Trindade, párrafo 47, p. 15. 
la inacción, la abstención de sus autoridades frente a esta práctica. En definitiva — señaló la Corte de Justicia de la Comunidad, CEDEAO—al omitir plantear de oficio una prohibición de orden público y de tomar o de hacer tomar todas las medidas adecuadas para evitar la situación de esclavitud, el Estado de Níger ha comprometido su responsabilidad. ${ }^{63}$

Si entendemos la justicia constitucional como una justicia primordialmente salvaguardadora de los derechos humanos - comprendidos estos como un componente esencial de un Estado de derecho- entonces, se puede sostener que la Corte IDH realiza una especie de justicia constitucional. La Corte IDH, por medio de la cooperación judicial multinivel (vertical) con las Cortes nacionales - especialmente constitucionales - y del dialogo jurisprudencial (horizontal) con otras cortes de derechos humanos, contribuye a fijar los parámetros básicos comunes de un DADH y, por medio de este derecho, de un Estado de Derecho compartido que sobrevuela todos los órdenes nacionales americanos. ${ }^{64}$ Incluso más, desde la perspectiva de este orden constitucional global que tiene como eje central al individuo, a los grupos y comunidades, y la protección de sus derechos, y de la interacción importación - exportación entre Cortes u órganos constitucionales, Tushnet ha llegado a plantear el surgimiento de una visión constitucional transnacional. ${ }^{65}$ El ejemplo de la Unión Europea, donde la Corte de Justicia de la Unión y la Corte Europea de Derechos Humanos (en adelante, la Corte EDH) actúan como catalizadores de ese orden constitucional, le asigna razón a esta idea del profesor Tushnet.

En consecuencia, si pensamos que los derechos humanos o fundamentales constituyen el componente estructural medular del orden constitucional, tanto interno como internacional, entonces, desde esa perspectiva, se podría hablar de una justicia constitucional multidimensional o - como se le ha denominado en el contexto de un derecho y un gobierno global- multini-

63 Corte de Justicia de la CEDEAO, Caso Dame Hadjatou Mani Koraou c. Republica de Niger, Arret $\mathrm{N}^{\circ} \mathrm{ECW} / \mathrm{CCJ} / \mathrm{JUD} / 06 / 08$, du 27 octobre 2008, pars. 85-86. El destacado es nuestro.

64 Utilizando ideas expresadas por Bogdandy, la Corte IDH, actuando de la manera que se ha señalado, sienta las reglas básicas de una gobernanza supranacional (al menos, regional Americana). Cfr. Bogdandy, Armin von, "Die Minderheitenpolitik der Europäischen Union. Zugleich ein Beitrag zur rechtswissenschaftlichen Fassung überstaatlicher Governance", Kritische Justiz, vol. 40, núm. 3 (2007), pp. 224-239.

65 "This cross-fertilization between separate constitutional cultures, which appears to be in process, may create an important bridge toward the ultimate creation of a shared, transnational constitutional vision". Tushnet, Mark, op. cit, nota 24. 
vel. ${ }^{66}$ Se ha propuesto que en la época actual la protección de los derechos fundamentales viene proporcionada en distintos niveles, porque se cautela lo que hemos denominado precedentemente "orden constitucional", en varios niveles verticales, esto es, al menos en América, en el nivel nacional y regional internacional. ${ }^{67}$

En este sentido, todos los niveles jurisdiccionales tienen un rol importante a jugar en la construcción y fortalecimiento constante de un "orden público americano", primordialmente, los órganos jurisdiccionales constitucionales de los Estados y, esencialmente, en su calidad de supremo intérprete de los derechos humanos en el Continente, la Corte Interamericana de Derechos Humanos. En efecto, como ha señalado el juez Cançado Trindade, la Corte IDH cumple una "función de órgano judicial máximo de salvaguardia de los derechos humanos en el sistema interamericano de protección, y en el marco de la universalidad de los derechos humanos". ${ }^{68}$

La reflexión sobre un orden público americano tiene al individuo como sujeto primordial de derecho, desde el punto de vista del Estado de derecho, tanto en el contexto del orden interno de los Estados como en el contexto del orden internacional, ya que ha habido, como señala Petersmann, una progresiva transformación del derecho internacional desde las normas centradas en el Estado hacia las normas centradas en el individuo, de lo cual también puede dar testimonio el derecho constitucional contemporáneo. Por esta razón es que estamos de acuerdo con la afirmación de Petersmann en el sentido de que "[h]uman rights require all governments and intergovernmental organisations to review how the power-oriented structures of the Westphalian 'international law among states' must be restructured so as to respect citizens as legal subjects and protect and promote human rights more effectively". ${ }^{69}$

${ }^{66}$ Cfr. Aalberts, Tanja E., "The Future of Sovereignty in Multilevel Governance Europe - A Constructivist Reading", Journal of Common Market Studies, vol. 42, núm. 1, 2004, pp. 23-46.

${ }^{67}$ Para examinar una aplicación de este gobierno judicial multinivel en Europa, vid. Petersmann, Ernst-Ulrich, "Human Rights, International Economic Law and 'Constitutional Justice”, The European Journal of International Law, Vol. 19, num. 4 (2008), pp. 769-798, especialmente, p. 775.

${ }^{68}$ Corte IDH, Caso Del Penal Miguel Castro Castro vs. Perú, Interpretación de la Sentencia de Fondo, Reparaciones y Costas, Sentencia del 2 de agosto de 2008 Serie C, núm. 181, Voto razonado del juez Antônio Augusto Cançado Trindade, párrafo 153.

69 Petersmann, Ernst-Ulrich, "Human Rights, International Economic Law and 'Constitutional Justice'”, The European Journal of International Law, Vol. 19, num. 4 (2008), 
Utilizando estas dos herramientas - tradiciones constitucionales e instrumentos internacionales de derechos humanos - como fuentes de inspiración, indudablemente que se irá configurando el sistema de derechos humanos propio del ordenamiento jurídico latinoamericano, el cual, en definitiva, será el sustento y fundamento de un verdadero espacio público americano. ${ }^{70}$ Este espacio público americano se encuentra dotado, desde un punto de vista jurídico, de un verdadero orden constitucional, esto es, de un 'orden público americano', compuesto por los valores y principios de los derechos humanos, y en cuya cúspide se encontrarían las normas de ius cogens.

Así, como ha sido reconocido, tanto en el ámbito europeo como en el ámbito americano, la existencia de un orden público constitucional, el sistema de derechos humanos admite y reconoce las particularidades culturales de las distintas comunidades y pueblos. ${ }^{71}$ En virtud de este reconocimiento, es posible que las orientaciones o los énfasis impresos al orden público europeo no sea el mismo que aquel aplicado al orden público americano, si bien, en gran medida, ambos órdenes coincidirán en su contenido. Con todo, en lo que dice relación con aquellas normas que se encuentran fuera del acuerdo convencional, y que vinculan al individuo, a las comunidades y pueblos, en todo momento y bajo cualquier circunstancia, dichas normas imperativas conforman omnium gentium un orden público internacional.

De este modo, la Declaración Americana de Derechos y Deberes del Hombre y la Convención Americana sobre Derechos Humanos, son los instrumentos constitucionales principales del orden público americano, por la particular naturaleza de estos instrumentos, por el carácter objetivo de sus disposiciones y por la instauración de un sistema de garantía colectiva

pp. 769-798, especialmente, p. 771.

70 Para un desarrollo de esta idea, aplicada al continente Europeo, vid. Innerarity Grau, Daniel, "El espacio público europeo", Claves de razón práctica, núm. 175 (2007), pp. 24-31.

71 “Todos los derechos humanos son universales, indivisibles e interdependientes y están relacionados entre sí. La comunidad internacional debe tratar los derechos humanos en forma global y de manera justa y equitativa, en pie de igualdad y dándoles a todos el mismo peso. Debe tenerse en cuenta la importancia de las particularidades nacionales y regionales, así como de los diversos patrimonios históricos, culturales y religiosos, pero los Estados tienen el deber, sean cuales fueren sus sistemas políticos, económicos y culturales, de promover y proteger todos los derechos humanos y las libertades fundamentales". Véase Declaración y Programa de Acción de Viena, aprobada por la Conferencia Mundial de Derechos Humanos el 25 de junio de 1993. Doc. A/CONF.157/23, del 12 de julio de 1993, párrafo 5. 
del respeto a los derechos humanos. Este orden público se funda, además, en que los Estados Americanos han declarado que:

la consagración americana de los derechos esenciales del hombre unida a las garantías ofrecidas por el régimen interno de los Estados, establece el sistema inicial de protección que los Estados americanos consideran adecuado a las actuales circunstancias sociales y jurídicas, no sin reconocer que deberán fortalecerlo cada vez más. ${ }^{72}$

Como ya se ha mencionado precedentemente, en el ámbito americano se ha resaltado el principio de la solidaridad, entre otros instrumentos jurídicos, en la Carta de la Organización de Estados Americanos (en adelante, la OEA $)^{73} \mathrm{y}$, además, por supuesto, en la Convención Americana sobre Derechos Humanos, en cuyo preámbulo, los Estados americanos han reafirmado "su propósito de consolidar en este Continente, dentro del cuadro de las instituciones democráticas, un régimen de libertad personal y de justicia social, fundado en el respeto de los derechos esenciales del hombre" y, junto con ello, han reiterado que "con arreglo a la Declaración Universal de los Derechos Humanos, sólo puede realizarse el ideal del ser humano libre, exento del temor y de la miseria, si se crean condiciones que permitan a cada persona gozar de sus derechos económicos, sociales y culturales, tanto como de sus derechos civiles y políticos". ${ }^{74}$ Unido a lo anterior, hay que mencionar el Protocolo de San Salvador, que complementa la $\mathrm{CADH}$, en cuyo preámbulo los Estados han afirmado "la estrecha relación que existe entre la vigencia de los derechos económicos, sociales y culturales y la de los derechos civiles y políticos, por cuanto las diferentes categorías

72 Cfr. Preámbulo, Declaración Americana de los Derechos y Deberes del Hombre (Aprobada en la Novena Conferencia Internacional Americana, Bogotá, Colombia, 1948).

73 Los pueblos de América están "[s]eguros de que el sentido genuino de la solidaridad americana y de la buena vecindad no puede ser otro que el de consolidar en este Continente, dentro del marco de las instituciones democráticas, un régimen de libertad individual y de justicia social, fundado en el respeto de los derechos esenciales del hombre". Preámbulo de la Carta de la Organización de los Estados Americanos, suscrita en Bogotá en 1948 y reformada por el Protocolo de Buenos Aires en 1967, por el Protocolo de Cartagena de indias en 1985, por el Protocolo de Washington en 1992, y por el Protocolo de Managua en 1993.

74 Véase Preámbulo, Convención Americana sobre Derechos Humanos, suscrita en la Conferencia Especializada Interamericana sobre Derechos Humanos. San José de Costa Rica, 7 al 22 de noviembre de 1969. 
de derechos constituyen un todo indisoluble que encuentra su base en el reconocimiento de la dignidad de la persona humana, por lo cual exigen una tutela y promoción permanente con el objeto de lograr su vigencia plena, sin que jamás pueda justificarse la violación de unos en aras de la realización de otros" $\mathrm{y}$, además, han resaltado que:

si bien los derechos económicos, sociales y culturales fundamentales han sido reconocidos en anteriores instrumentos internacionales, tanto de ámbito universal como regional, resulta de gran importancia que éstos sean reafirmados, desarrollados, perfeccionados y protegidos en función de consolidar en América, sobre la base del respeto integral a los derechos de la persona, el régimen democrático representativo de gobierno, así como el derecho de sus pueblos al desarrollo, a la libre determinación y a disponer libremente de sus riquezas y recursos naturales. ${ }^{75}$

Además, los Estados miembros, en la Asamblea General de la OEA, reiteraron, en 1991, su reconocimiento expreso al principio de solidaridad como componente esencial del orden constitucional regional. Así, en la Resolución 1080 de 1991, los Estados declararon que:

teniendo en cuenta la existencia generalizada de gobiernos democráticos en el Hemisferio, es necesario darle efectiva aplicación al principio consignado en la Carta de que la solidaridad de los Estados americanos y los altos fines que con ella se persiguen requieren la organización política de los mismos sobre la base del ejercicio efectivo de la democracia representativa. ${ }^{76}$

A estos instrumentos jurídicos, hay que sumar otros no vinculantes - al menos en cuanto tales - tales como la Declaración Americana de Derechos y Deberes del Hombre (en adelante, la DADDH), cuyo preámbulo ya en 1948, adelantaba el surgimiento, en cierne, de este DADH, al

75 Preámbulo del Protocolo Adicional a la Convención Americana sobre Derechos Humanos en materia de Derechos Económicos, Sociales y Culturales, Protocolo de San Salvador. Adoptado en San Salvador, El Salvador, con fecha 17 de noviembre de 1988, y entrado en vigor con fecha 16 de noviembre de 1999.

76 Véase Democracia Representativa. Doc. AG/RES. 1080 (XXI-O/91). Resolución aprobada en la quinta sesión plenaria, celebrada el 5 de junio de 1991. 
señalar que "la protección internacional de los derechos del hombre debe ser guía principalísima del derecho americano en evolución". ${ }^{77}$

Junto con los compromisos jurídicos, existen instrumentos internacionales que contienen relevantes compromisos políticos de los Estados de América y que reconocen asimismo el principio de solidaridad y el de justicia social. En este sentido conviene tener presente la importancia que en derecho internacional tienen las declaraciones y otras manifestaciones oficiales de voluntad de los agentes de los Estados como fuente de obligaciones internacionales. Además, estas declaraciones son relevantes puesto que pueden contribuir a la generación o cristalización de una costumbre internacional, la cual es una importante fuente del derecho internacional.

En efecto, durante la V Reunión de Consulta de los Ministros de Relaciones Exteriores de América, reunida en Santiago de Chile en 1959, se adoptó la "Declaración de Santiago de Chile", la cual señala los rasgos fundamentales que un régimen democrático debería tener en el continente. Así, la Declaración señala que "los Gobiernos deben surgir de elecciones libres y mantener un régimen de libertad individual y de justicia social, fundado en el respeto de los derechos fundamentales de la persona humana; que el imperio de la ley debe asegurarse mediante la independencia de los poderes, y la fiscalización de la legalidad de los actos del gobierno por órganos jurisdiccionales del Estado; que la perpetuación en el poder o el ejercicio de éste sin plazo determinado y con manifiesto propósito de perpetuación, son incompatibles con e1 ejercicio de la democracia". ${ }^{78}$

En 1991, los ministros de Relaciones Exteriores y jefes de Delegación de los países miembros de la Organización de los Estados Americanos aprobaron el denominado Compromiso de Santiago con la democracia y con la renovación del sistema interamericano, en el cual declaran su decisión de "intensificar la lucha solidaria y la acción cooperadora contra la pobreza crítica para contribuir a disminuir las desigualdades económicas y sociales en el hemisferio, fortaleciendo así el proceso de promoción y consolidación de la democracia en la región" ${ }^{79}$ Asimismo, decidieron "contribuir a

77 Preámbulo de la Declaración Americana de los Derechos y Deberes del Hombre (aprobada en la Novena Conferencia Internacional Americana), Bogotá, Colombia, 1948.

78 Fernández Shaw, Félix G., "Reuniones de Consulta de Ministros de Relaciones Exteriores de América", Revista de Política Internacional, núm. 52, noviembre-diciembre de 1960, pp. 95-116, especialmente, p. 99.

79 Véase Compromiso de Santiago con la democracia y con la renovación del sistema interamericano. Aprobado en Santiago de Chile, el 4 de junio de 1991, en la tercera se- 
la Protección solidaria del medio ambiente para beneficiar a las presentes y futuras generaciones asegurando un desarrollo sustentable en la región". ${ }^{80}$

En la Declaración de Santiago, de 2007, las jefas y los jefes de Estado y de gobierno de los veintidós países miembros de la Comunidad Iberoamericana, reiteraron su adhesión al principio de solidaridad, comprometiéndose con la cohesión social y las políticas sociales, consolidando así sociedades más articuladas y solidarias en el marco de la diversidad de los Estados iberoamericanos. ${ }^{81}$ Resulta destacable el compromiso adquirido por los Estados en el sentido de fortalecer la promoción y respeto de todos los derechos humanos como un componente indispensable en la adopción y ejecución de las políticas destinadas a lograr la cohesión social. ${ }^{82}$

En el caso de la Declaración de San Salvador de la XVIII Cumbre Iberoamericana, de 2008, los Estados miembros expresaron que reconocían la

importancia que reviste para el presente y futuro de nuestras sociedades el atender las necesidades de la juventud, como protagonista y beneficiario del desarrollo y de políticas públicas, orientadas a garantizar los más elevados niveles de equidad, justicia social, solidaridad, participación e inclusión en nuestros pueblos. Y, además, acordaron, desarrollar políticas que promuevan en la juventud iberoamericana los valores de la solidaridad, justicia, tolerancia, igualdad, equidad y paz; así como su activa participación como actores sociales protagónicos del desarrollo, en el contexto de un mundo globalizado e interdependiente. ${ }^{83}$

sión plenaria del Vigésimo Primer Periodo Ordinario de Sesiones de la Asamblea General de la Organización de Estados Americanos. Doc. OEA/Ser.P/AG/doc. 2734/91, 4 junio 1991, letra a).

80 Véase Compromiso de Santiago con la democracia y con la renovación del sistema interamericano. Aprobado en Santiago de Chile, el 4 de junio de 1991, en la tercera sesión plenaria del Vigésimo Primer Periodo Ordinario de Sesiones de la Asamblea General de la Organización de Estados Americanos. Doc. OEA/Ser.P/AG/doc. 2734/91, 4 junio 1991, letra e).

81 Véase Declaración de Santiago, XVII Cumbre Iberoamericana de Jefes de Estado y de Gobierno 8, 9 y 10 de noviembre de 2007, párrafo 12.

${ }^{82}$ Véase Declaración de Santiago, XVII Cumbre Iberoamericana de Jefes de Estado y de Gobierno 8, 9 y 10 de noviembre de 2007, párrafo 13.

83 Véase Declaración de San Salvador. XVIII Cumbre Iberoamericana de Jefas y Jefes de Estado y de Gobierno de los veintidós países miembros de la Comunidad Iberoamericana, reunidos en la ciudad de San Salvador, República de El Salvador, en 2008, párrafo 2 . 
En el contexto de las Cumbres de las Américas, los jefes de Estado y de gobierno también han reiterado el principio de solidaridad y de justicia social. Así, en la Cuarta Cumbre de las Américas, de 2005, las jefas y los jefes de Estado y de gobierno de los países democráticos de las Américas señalaron expresamente: "Reafirmamos que el carácter participativo de la democracia en nuestros países, en los diferentes ámbitos de la actividad pública, contribuye a la consolidación de los valores democráticos y a la libertad y la solidaridad en el Hemisferio". ${ }^{84}$

Por su parte, en la Quinta Cumbre de las Américas, de 2009, las jefas y los Jefes de Estado y de Gobierno de los países democráticos de las Américas, declararon que actuaban "guiados por un espíritu renovado de cooperación, integración y solidaridad" ${ }^{85}$ Luego, los jefes de Estado de las Américas reafirman todos los principios y valores contenidos en la Carta de la OEA, por lo tanto, el principio de solidaridad y de justicia social y continúan para señalar que:

nuestra concepción de seguridad en el Hemisferio incorpora las prioridades de cada Estado, contribuye a la consolidación de la paz, el desarrollo integral y la justicia social, y se basa en valores democráticos, el respeto, la promoción y defensa de los derechos humanos, la solidaridad, la cooperación y el respeto a la soberanía nacional. ${ }^{86}$

84 Véase Declaración de Mar del Plata: "Crear Trabajo para Enfrentar la Pobreza y Fortalecer la Gobernabilidad Democrática”, Cuarta Cumbre de las Américas, Mar del Plata, Argentina, 5 de noviembre de 2005, párrafo 60, p. 12.

85 "Reafirmamos los principios y valores de la Carta de la Organización de las Naciones Unidas, la Carta de la Organización de los Estados Americanos (OEA), la Carta Democrática Interamericana, el Consenso de Monterrey sobre Financiación para el Desarrollo y la Declaración del Milenio; y estamos decididos a intensificar nuestra lucha contra la pobreza, el hambre, la exclusión social, la discriminación y la desigualdad, así como promover la inclusión y la cohesión social para mejorar las condiciones de vida de nuestros pueblos y alcanzar el desarrollo y la justicia social". Véase Declaración de Compromiso de Puerto España: Asegurar el futuro de nuestros ciudadanos promoviendo la prosperidad humana, la seguridad energética y la sostenibilidad ambiental. Quinta Cumbre de las Américas, Puerto España, Trinidad y Tobago, 19 de abril de 2009. Doc. OEA/Ser.E, CA-V/DEC.1/09, 19 de abril de 2009, párrafo 2.

86 Véase Declaración de Compromiso de Puerto España: Asegurar el futuro de nuestros ciudadanos promoviendo la prosperidad humana, la seguridad energética y la sostenibilidad ambiental. Quinta Cumbre de las Américas, Puerto España, Trinidad y Tobago, 19 de abril de 2009. Doc. OEA/Ser.E, CA-V/DEC.1/09, 19 de abril de 2009, párrafo 68. 
De esta manera, se podría sostener que el principio de solidaridad, es un principio estructural del orden constitucional internacional americano y que, en cuanto tal, constituye uno de los rasgos distintivos del DADH.

Estos instrumentos jurídicos, que contienen y reconocen el principio de solidaridad, contribuyen, inter alia, a determinar el orden jurídico americano. De esta manera, el estándar mínimo de derechos humanos compone y configura un espacio público americano, que desde el punto de vista normativo, se llena de contenido por medio del orden público americano. El orden público americano fija el marco jurídico mínimo dentro del cual los Estados — constitucionales y democráticos - americanos pueden moverse para alcanzar grados avanzados de justicia social. Por medio del DADH, el Estado latinoamericano es un Estado democrático, multicultural y comunitario, gracias al fuerte contenido humanista, que el especial sentido de comunidad existente en el continente, le impregna a los derechos humanos, especialmente, a los DESC. Dicho de otro modo, los derechos humanos, particularmente, los DESC, son leídos en América Latina a la luz del fuerte sentido de comunidad que existe en la región, en cuyo seno se aloja un poderoso componente de solidaridad. Esto último explica que el Estado constitucional latinoamericano pueda ser visto, desde la óptica del DADH, como un Estado democrático, multicultural y comunitario de derechos.

En este contexto, como se ha dicho, el DADH puede caracterizarse por la consagración de la diversidad cultural y del reconocimiento de la identidad cultural como derecho humano colectivo, por el desarrollo, en la última década, de su doctrina en materia de los derechos sociales, y por el reconocimiento expreso de normas de ius cogens. A continuación se examinara brevemente cada uno de estos particularismos del DADH.

\section{Perfil especifico y contenido del DADH}

¿Cuál es el contenido normativo concreto de este DADH, que lo hace diferente del DIDH y también del DEDH y del DADH? Para enfrentar esta pregunta vale la pena, en primer lugar, tener en cuenta que, tal vez, los contenidos de los derechos no son diversos - salvo el caso especial de los derechos de los pueblos indígenas y la extensión y contenido que se la ha dado al dominio del ius cogens - pero la aplicación e interpretación que de dichos derechos se hace, es diversa, esto es, más elástica, extensa, flexible, o también, puede ser, más estricta o reducida. 
Reiteramos, en esta parte, que cuando hablamos del DADH nos estamos refiriendo a aquellas normas, principios y estándares que han ido surgiendo producto del establecimiento de un sistema interamericano de protección de los derechos humanos y, particularmente, a partir de la actividad de la Corte IDH, y que constituyen los rasgos definidores o distintivos de los derechos humanos en el continente americano.

Entre estos rasgos distintivos o diferenciadores, podemos mencionar (a) la protección de la diversidad cultural, (b) los desarrollos respecto de los DESC y (c) la jurisprudencia dinámica y extensiva en el dominio del ius cogens.

\section{A. Promoción y protección de la diversidad cultural}

La proyección de la diversidad cultural en la esfera de los derechos humanos se ha producido con especial énfasis en el ámbito latinoamericano, gracias a la especificidad de la composición étnica del continente americano, en particular, de la presencia de pueblos indígenas y de población afrodescendiente. La forma en que se ha ido produciendo el reconocimiento gradual de la diversidad cultural en el DADH es doble.

Por un lado, la Corte IDH ha ido reconociendo los derechos de los miembros de los pueblos indígenas, teniendo en cuenta sus características etnoculturales y sus derechos específicos. Por otro lado, en un grado más avanzado, la Corte IDH también ha reconocido derechos humanos colectivos de la comunidad indígena en cuanto tal y, con ello, su capacidad jurídica como sujetos de derecho internacional. ${ }^{87}$ En esta línea, la Corte IDH ha enfatizado, en el Caso del Pueblo Saramaka, que "el pueblo Saramaka es un grupo tribal distinto, cuyos miembros gozan y ejercen ciertos derechos de manera colectiva" ${ }^{88}$ lo que, dicho de otro modo, implica reconocerlos como "sujet à part entière".

Al mismo tiempo, un elemento característico de las modernas democracias constitucionales comunitarias de América Latina es su claro componente

87 Brunner, Lis, “The Rise of Peoples' Rights in the Americas: The Saramaka People Decision of the Inter-American Court of Human Rights", Chinese Journal of International Law, vol. 7, num. 3 (2008), pp. 699-711.

88 Corte IDH, Caso Comunidad Indigena Yakye Axa vs. Paraguay, Fondo Reparaciones y Costas, Sentencia 17 de junio de 2005, Serie C, núm. 125; Corte IDH, Caso del Pueblo Saramaka vs. Surinam, Excepciones Preliminares, Fondo, Reparaciones y Costas, Sentencia del 28 de noviembre de 2007, Serie C, núm. 172, párrafo 65, p. 52. 
multicultural, lo que resalta el enfoque comunitario que se le está imprimiendo a las Constituciones de la región. ${ }^{89}$

Los pueblos indígenas, como colectivo organizado, han irrumpido definitivamente en la escena político-constitucional e internacional de América Latina, y lo han hecho para quedarse. A lo largo de las últimas tres décadas, estos pueblos han dejado sentir la reivindicación de sus derechos específicos $\mathrm{y}$, particularmente, sus derechos a las tierras y territorios que tradicionalmente les han pertenecido. Los pueblos indígenas han sido particularmente exitosos no sólo en el reconocimiento constitucional de su existencia y de sus derechos, sino además, en los litigios ante órganos jurisdiccionales, donde han reivindicado sus derechos.

Fruto de esta movilización, la identidad cultural ha pasado a ser un elemento identificador de las democracias constitucionales comunitarias y multiculturales, donde el individuo no pasa a tener derechos conforme a un patrón de derechos abstracto homogéneamente definidos, sino donde el individuo tiene los derechos fundamentales básicos que la Constitución asegura a todos y además aquellos que le corresponde conforme a su identidad cultural. ${ }^{90}$ Así, el individuo se encuentra reconocido como parte integrante de la sociedad estatal en cuanto ciudadano y además, conforme a su identidad cultural.

Además, la democracia constitucional multicultural, implica un reconocimiento de las comunidades y pueblos y de los distintos grupos componentes de la sociedad, tales como los pueblos indígenas, las minorías, los inmi-

89 Véase Aguilar, Gonzalo et al., "Modelos de reconocimiento constitucional de los pueblos indígenas en America Latina”, en Ministerio Secretaría General de la Presidencia, Participación y nuevos desafios político-institucionales, Serie Estudios, Santiago de Chile, Vol. III, 2009, pp. 149-205.

${ }^{90}$ Los Estados del continente, reunidos en la Quinta Cumbre de las Américas en 2009, han señalado, a este respecto, lo siguiente: "Reconociendo la diversidad y el carácter tradicional y ancestral de las culturas, historias y circunstancias demográficas, socioeconómicas y políticas de los pueblos indígenas, reafirmamos nuestro compromiso de respetar sus derechos, y promoveremos la conclusión exitosa de las negociaciones de la Declaración Americana sobre los Derechos de los Pueblos Indígenas. El reconocimiento de los derechos de los pueblos indígenas es esencial para su existencia, bienestar y desarrollo integral. De acuerdo con la legislación nacional de cada Estado, promoveremos el ejercicio de sus derechos, su plena participación en las actividades nacionales y la creación de las condiciones que les permitan superar la pobreza, la exclusión social y la desigualdad". Véase Declaración de Compromiso de Puerto España, Quinta Cumbre de las Américas, realizada del 17 al 19 de abril de 2009, en Puerto España, Trinidad y Tobago, párrafo 86. 
grantes, etc. todos los cuales merecen una protección especial, mediante el respectivo reconocimiento constitucional, debido a su particular situación de vulnerabilidad. En este contexto, la democracia constitucional multicultural comprende, además, los derechos humanos colectivos por contraposición a los derechos - eminentemente individuales - del constitucionalismo liberal. En este sentido, es sintomática la aparición, en las diversas Constituciones de América Latina, de reconocimientos expresos del multiculturalismo y de derechos colectivos. De este grupo, sin lugar a dudas, las Constituciones más avanzadas en este sentido son las Constituciones de Venezuela, Ecuador y Bolivia, lo cual, sin duda, representa un progreso para el desarrollo humano en dichos Estados, a pesar de las críticas que se puedan hacer al proceso constitucional seguido o al régimen constitucional que dichas reformas pretenden instaurar. Por su parte, la Constitución Política de Chile y de Uruguay pueden ser destacadas como unas de las escasas Constituciones de América Latina que no han incorporado el reconocimiento del multiculturalismo ni los derechos de los pueblos indígenas, lo que demuestra el carácter claramente refractario de la clase política y de los operadores jurídicos, frente al constitucionalismo incluyente y multicultural del tercer milenio, es decir, un multiculturalismo donde todos tienen cabida, con el reconocimiento y respeto de sus propias especificidades.

A pesar de los avances y progresos logrados en materia de reforma constitucional y de reconocimiento constitucional de los pueblos indígenas y de los derechos de los pueblos indígenas, subsiste una cultura de exclusión, racismo y discriminación. Esta cultura fue cimentada por el constitucionalismo liberal que a lo largo de siglos han olvidado a los pueblos indígenas asumiendo como parámetro constitucional la figura del colonizador y enarbolando la bandera, que hoy se ha revelado falaz, de que todas las personas son iguales. En virtud de este principio de igualdad, se ha preterido al indígena, se lo ha aislado y se lo ha excluido y se han cometido grandes violaciones de derechos humanos. En virtud de este principio de igualdad se ha terminado de desposeer al indígena de sus derechos. Esta cultura constitucional forjada en los albores de nuestra vida republicana, subsiste hoy en día. Una reacción real, y concretamente posible, inspirada por el motor de los derechos humanos, es reconocer que no todos los individuos se encuentran en un pie de igualdad y que es necesario corregir las desigualdades de la sociedad, mediante tratamientos diferenciados - objetivos, razonables y proporcionados - a fin de restablecer una igualdad de derechos, que en los hechos, no existe. 
Según el DIDH, es deber del Estado diseñar sus políticas públicas e implementar programas con base en las normas constitucionales e internacionales de derechos humanos a fin de acortar paulatinamente la brecha entre desarrollo normativo y cultura constitucional en el ámbito de la identidad cultural. En este sentido, en el ámbito universal se puede mencionar, la Declaración sobre la Raza y los Prejuicios Raciales, adoptada en París el 28 de noviembre de 1978, en el seno de la Unesco. ${ }^{91}$ Además, la Declaración Universal de la Unesco sobre la Diversidad Cultural, aprobada el 2 de noviembre de 2001. Esta Declaración en su artículo 1o. señala que:

[1]a cultura adquiere formas diversas a través del tiempo y del espacio. Esta diversidad se manifiesta en la originalidad y la pluralidad de las identidades que caracterizan a los grupos y las sociedades que componen la humanidad. Fuente de intercambios, de innovación y de creatividad, la diversidad cultural es tan necesaria para el género humano como la diversidad biológica para los organismos vivos. En este sentido, constituye el patrimonio común de la humanidad y debe ser reconocida y consolidada en beneficio de las generaciones presentes y futuras.

Junto con lo anterior, existe la relevante Convención para la Salvaguardia del Patrimonio Cultural Inmaterial, adoptada en París el 17 de octubre de 2003..$^{92}$ Sin lugar a dudas, el avance más importante respecto de la protección de la diversidad cultural, a nivel normativo, es la Convención sobre la Protección y Promoción de la diversidad de las expresiones culturales, adoptada en París, el 20 de octubre de $2005 .{ }^{93} \mathrm{El}$ artículo 4.1. de la referida Convención señala que "[1]a "diversidad cultural” se refiere a la multiplicidad

91 "Artículo 1o.: Todos los individuos y los grupos tienen derecho a ser diferentes, a considerarse y ser considerados como tales". Declaración sobre la raza y los prejuicios raciales, adoptada por la Conferencia General de la Organización de las Naciones Unidas para la Educación, la Ciencia y la Cultura, reunida en París en su 20 a reunión, del 24 de octubre al 28 de noviembre de 1978, doc. E/CN.4/Sub.2/1982/2/Add.1, anexo V (1982).

${ }^{92}$ Hasta el 30 de octubre de 2009 esta Convención tenía 117 Estados Partes. La Convención para la Salvaguardia del Patrimonio Cultural Inmaterial entró en vigor el 20 de abril de 2006.

93 Hasta octubre de 2009, 103 Estados eran partes en esta Convención. La Convención sobre la protección y promoción de la diversidad de las expresiones culturales entró en vigor el 18 de marzo de 2007. Los siguientes países del continente americano son partes en esta Convención: Argentina, Barbados, Bolivia, Brasil, Canadá, Chile, Cuba, Ecuador, Granada, Guatemala, Jamaica, México, Nicaragua, Panamá, Paraguay, Perú, Republica Dominicana, San Vicente y las Granadinas, Santa Lucia y Uruguay. 
de formas en que se expresan las culturas de los grupos y sociedades. Estas expresiones se transmiten dentro y entre los grupos y las sociedades. La diversidad cultural se manifiesta no sólo en las diversas formas en que se expresa, enriquece y transmite el patrimonio cultural de la humanidad mediante la variedad de expresiones culturales, sino también por medio de distintos modos de creación artística, producción, difusión, distribución y disfrute de las expresiones culturales, cualesquiera que sean los medios y tecnologías utilizados". Además, no se puede dejar de mencionar la Declaración de las Naciones Unidas sobre los derechos de los pueblos indígenas, Resolución aprobada por la Asamblea General, 13 de septiembre de 2007, aprobada por una mayoría de más de 140 Estados.

En el ámbito regional americano, existe, aun en negociación, el Proyecto de Declaración Americana sobre los derechos de los pueblos indígenas. ${ }^{94}$ Además, la Carta Cultural Iberoamericana, de 2006, adoptada en la Cumbre Iberoamericana de Jefes de Estado y de Gobierno, realizada en Montevideo (Uruguay), el 4 y 5 de noviembre de 2006. Esta Carta, que tiene como objetivo preciso, reforzar la Convención sobre la protección y promoción de la diversidad de las expresiones culturales, de 2005, consagra como principio rector que

[1]os derechos culturales deben ser entendidos como derechos de carácter fundamental según los principios de universalidad, indivisibilidad e interdependencia. Su ejercicio se desarrolla en el marco del carácter integral de los derechos humanos, de forma tal, que ese mismo ejercicio permite y facilita, a todos los individuos y grupos, la realización de sus capacidades creativas, así como el acceso, la participación y el disfrute de la cultura. Estos derechos son la base de la plena ciudadanía y hacen de los individuos, en el colectivo social, los protagonistas del quehacer en el campo de la cultura.

Un ejemplo de la recepción por la jurisprudencia interamericana de este reconocimiento y protección de la diversidad cultural, lo encontramos en el caso de la Comunidad Indígena Yakye Axa, de 2005. En este caso, la Corte reconoce a la comunidad indígena como un sujeto pleno de dere-

94 Registro del estado actual del Proyecto de Declaración Americana sobre los Derechos de los Pueblos Indígenas (resultados de las Once Reuniones de Negociación para la Búsqueda de Consensos celebradas por el Grupo de Trabajo). Doc. GT/DADIN/ doc. 334/08 rev. 4, 19 noviembre 2009. Véase www.oas.org/OASpage/Events/default. asp?eve_code $=11$. 
chos colectivos preexistentes a cualquier reconocimiento que se realice en el orden interno. En efecto, la Corte "considera que el otorgamiento de personería jurídica sirve para hacer operativos los derechos ya existentes de las comunidades indígenas, que los vienen ejerciendo históricamente y no a partir de su nacimiento como personas jurídicas. Sus sistemas de organización política, social, económica, cultural y religiosa, y los derechos que ello apareja, como la designación de sus propios líderes y el derecho a reclamar sus tierras tradicionales, son reconocidos no a la persona jurídica que debe inscribirse para cumplir con un formalismo legal, sino a la comunidad en sí misma que la propia Constitución paraguaya reconoce como preexistente al Estado". ${ }^{95}$

\section{B. Promoción y protección de los DESC}

Dentro de los avances que se han producido en estas últimas décadas, se encuentra el lento posicionamiento, en un lugar de relevancia en la agenda político-constitucional de los países de la región, de los derechos económicos, sociales y culturales. No es que los Estados de la región hayan superado con éxito todas las exigencias derivadas de la plena satisfacción de los derechos civiles y políticos, y muestra de ello son los defectos que aún subsisten en muchos países en relación con el derecho al debido proceso, pero se ha posicionado, en términos relativamente equivalentes, el debate constitucional en torno a los derechos económicos, sociales y culturales.

En esta línea, la superación de la tradicional distinción entre derechos fundamentales y derechos humanos contribuiría a la adquisición de 'ciudadanía plena' de los DESC en el orden estatal y permitiría la desaparición definitiva de la distinción, que ha predominado en los ordenes estatales, en cuanto al carácter mismo de derechos, de los DESC.

El orden internacional, mucho más dinámico que el orden constitucional en esta materia, ha evolucionado progresivamente mediante la adopción de un nuevo Protocolo Facultativo al Pacto Internacional de Derechos Eco-

95 "La comunidad indígena, para la legislación paraguaya, ha dejado de ser una realidad fáctica para pasar a convertirse en sujeto pleno de derechos, que no se reducen al derecho de sus miembros individualmente considerados, sino se radican en la comunidad misma, dotada de singularidad propia". Corte IDH, Caso Comunidad Indigena Yakye Axa vs. Paraguay, Fondo Reparaciones y Costas, Sentencia 17 de junio de 2005, Serie C, núm. 125 , pars. $82-83$, p. 65. 
nómicos, Sociales y Culturales, que contempla la posibilidad de aceptar la competencia del Comité de Derechos Económicos, Sociales y Culturales, para recibir denuncias individuales. ${ }^{96}$ Desde la perspectiva interamericana, el Protocolo de San Salvador, adoptado en 1988 y entrado en vigor en 1999, representa una evolución cualitativa de los derechos económicos, sociales y culturales. Esta normativa representa un paso importante en el respeto y protección de los DESC en el sistema interamericano y viene a complementar la escasa normativa regional ya existente, entre otros instrumentos, la Carta Internacional Americana de Garantías Sociales o Declaración de los Derechos Sociales del Trabajador, aprobada en la 9a. Conferencia Internacional Americana, en Bogotá, Colombia, en 1948. En este sentido, podría afirmarse junto con Cançado Trindade que "[e]n nuestros días, la conciencia jurídica universal ha despertado para reconocer judicialmente el sufrimiento humano y buscar su reparación mediante la garantía del primado de la Justicia en las relaciones humanas". ${ }^{97}$

La jurisprudencia de la Corte IDH, tímidamente, ha intentado pronunciarse sobre los DESC, en algunos casos contenciosos. Sin embargo, en nuestra opinión, los avances más notables que se han producido en esta materia,

96 El Protocolo Facultativo al Pacto Internacional de Derechos Económicos Sociales y Culturales fue adoptado por la Asamblea General de las Naciones Unidas, en ocasión del $60^{\circ}$ aniversario de la Declaración Universal de los Derechos Humanos, el 10 de diciembre de 2008, mediante la resolución A/RES/63/117. En dicha resolución, la Asamblea General recomienda que el Protocolo Facultativo sea abierto a la firma en una ceremonia el año 2009. Hasta noviembre de 2009, 30 Estados han firmado el Protocolo, de los cuales siete Estados de America Latina, a saber, Argentina, Chile, Ecuador, El Salvador, Guatemala, Paraguay, Uruguay; "Artículo 2. Comunicaciones: Las comunicaciones podrán ser presentadas por personas o grupos de personas que se hallen bajo la jurisdicción de un Estado Parte y que aleguen ser víctimas de una violación por ese Estado Parte de cualquiera de los derechos económicos, sociales y culturales enunciados en el Pacto. Para presentar una comunicación en nombre de personas o grupos de personas se requerirá su consentimiento, a menos que el autor pueda justificar que actúa en su nombre sin tal consentimiento". Protocolo Facultativo del Pacto Internacional de Derechos Económicos, Sociales y Culturales, adoptado por la Asamblea General mediante resolución A/ RES/63/117 adoptada el 10 de diciembre de 2008.

97 Corte IDH, Caso Goiburú y otros vs. Paraguay, Fondo, Reparaciones y Costas, Sentencia del 22 de septiembre de 2006, Serie C, núm. 153, Voto razonado del juez A. A. Cançado Trindade, párrafo 68, p. 23. 
en la Corte IDH, han provenido del ejercicio de la competencia consultiva, por ejemplo, en el caso de los Trabajadores Migrantes Indocumentados. ${ }^{98}$

En efecto, desde la perspectiva de los DESC, la actividad de la Corte IDH ha sido más bien recatada, por la escasez de mención de estos derechos en la Convención Americana sobre Derechos Humanos y por la debilidad que plantea el Protocolo de San Salvador, el cual, si bien reconoce esta clase de derechos, sólo contempla la jurisdicción de la Corte IDH y la posibilidad de presentar denuncias individuales, respecto de dos derechos. ${ }^{99}$ En efecto, el Protocolo de San Salvador redujo la posibilidad de presentar denuncias individuales a ciertos derechos sindicales y al derecho a la educación. ${ }^{100}$

98 Corte IDH, Condición Jurídica y Derechos de los Migrantes Indocumentados, Opinión Consultiva OC-18/03 del 17 de septiembre de 2003, Serie A, núm. 18.

99 Todos los países de América del Sur, salvo Chile y Venezuela, han ratificado el Protocolo de San Salvador. "Artículo 19: Medios de Protección: 6. En el caso de que los derechos establecidos en el párrafo a) del artículo 8 y en el artículo 13 fuesen violados por una acción imputable directamente a un Estado parte del presente Protocolo, tal situación podría dar lugar, mediante la participación de la Comisión Interamericana de Derechos Humanos, y cuando proceda de la Corte Interamericana de Derechos Humanos, a la aplicación del sistema de peticiones individuales regulado por los artículos 44 a 51 y 61 a 69 de la Convención Americana sobre Derechos Humanos". Protocolo Adicional a la Convención Americana sobre Derechos Humanos en materia de Derechos Económicos, Sociales y Culturales "Protocolo de San Salvador" (Suscrito en San Salvador, El Salvador, el 17 de noviembre de 1988, en el decimoctavo período ordinario de sesiones de la Asamblea General). Entrada en vigor: 16 de noviembre de 1999.

100 “Artículo 8: Derechos Sindicales: 1. Los Estados partes garantizarán: a. el derecho de los trabajadores a organizar sindicatos y a afiliarse al de su elección, para la protección y promoción de sus intereses. Como proyección de este derecho, los Estados partes permitirán a los sindicatos formar federaciones y confederaciones nacionales y asociarse a las ya existentes, así como formar organizaciones sindicales internacionales y asociarse a la de su elección. Los Estados partes también permitirán que los sindicatos, federaciones y confederaciones funcionen libremente"; "Artículo 13: Derecho a la Educación: 1. Toda persona tiene derecho a la educación. 2. Los Estados partes en el presente Protocolo convienen en que la educación deberá orientarse hacia el pleno desarrollo de la personalidad humana y del sentido de su dignidad y deberá fortalecer el respeto por los derechos humanos, el pluralismo ideológico, las libertades fundamentales, la justicia y la paz. Convienen, asimismo, en que la educación debe capacitar a todas las personas para participar efectivamente en una sociedad democrática y pluralista, lograr una subsistencia digna, favorecer la comprensión, la tolerancia y la amistad entre todas las naciones y todos los grupos raciales, étnicos o religiosos y promover las actividades en favor del mantenimiento de la paz. 3. Los Estados partes en el presente Protocolo reconocen que, con objeto de lograr el pleno ejercicio del derecho a la educación: a. la enseñanza primaria debe ser obligatoria y asequible a todos gratuitamente; b. la enseñanza secundaria en sus diferentes formas, incluso la enseñanza secundaria técnica y profesional, debe ser gene- 
En consecuencia, desde la perspectiva jurisdiccional, la competencia contenciosa de la Corte en materia de DESC ha sido discreta y ejercida con cautela. ${ }^{101}$ Aun cuando la actuación de la Corte IDH ha sido, más bien, recatada, se puede apreciar una modalidad novedosa en los esfuerzos por hacer realizables, concretos y justiciables los DESC, en un continente donde las desigualdades, la exclusión y la extrema pobreza - a diferencia de la realidad Europea - afectan a poblaciones enteras, especialmente, a aquellos más vulnerables, como indígenas, niños, mujeres, personas de edad y discapacitados. Por una parte, la Corte IDH ha efectuado una protección indirecta, que nosotros denominaremos par ricochet. ${ }^{102}$ Esta protección indirecta ha adquirido dos modalidades, por un lado, por medio de los derechos civiles y políticos y, por otros lado, mediante las reparaciones. Por otra parte, la Corte IDH ha recibido demandas por violación directa del artículo 26 de la $\mathrm{CADH}$, sin que, en esta circunstancia, haya declarado la violación del derecho. Sin embargo, lo que resulta interesante tener en consideración.

Como se ha dicho, queda por rescatar que la Corte IDH, al igual que lo ha hecho la Corte Europea de Derechos Humanos, y aun cuando sea indi-

ralizada y hacerse accesible a todos, por cuantos medios sean apropiados, y en particular por la implantación progresiva de la enseñanza gratuita; c. la enseñanza superior debe hacerse igualmente accesible a todos, sobre la base de la capacidad de cada uno, por cuantos medios sean apropiados y en particular, por la implantación progresiva de la enseñanza gratuita; d. se deberá fomentar o intensificar, en la medida de lo posible, la educación básica para aquellas personas que no hayan recibido o terminado el ciclo completo de instrucción primaria; e. se deberán establecer programas de enseñanza diferenciada para los minusválidos a fin de proporcionar una especial instrucción y formación a personas con impedimentos físicos o deficiencias mentales. 4. Conforme con la legislación interna de los Estados partes, los padres tendrán derecho a escoger el tipo de educación que habrá de darse a sus hijos, siempre que ella se adecue a los principios enunciados precedentemente. 5. Nada de lo dispuesto en este Protocolo se interpretará como una restricción de la libertad de los particulares y entidades para establecer y dirigir instituciones de enseñanza, de acuerdo con la legislación interna de los Estados partes".

${ }^{101}$ En este sentido, el propio juez García Ramírez ha señalado que reconoce "que la jurisprudencia de la Corte ha sido muy limitada, hasta hoy, en la referencia a los derechos de esta naturaleza [DESC]". Corte IDH, Caso Acevedo Buendía y otros ("Cesantes y Jubilados de la Contraloría”) vs. Perú, Excepción Preliminar, Fondo, Reparaciones y Costas, Voto concurrente del Juez Sergio García Ramírez, Sentencia del 1 de julio de 2009 Serie C, núm. 198, párrafo 16, p. 4

${ }^{102}$ Este concepto ha sido desarrollado inicialmente por el profesor Sudre a propósito de la jurisprudencia de la Corte Europea de Derechos Humanos. Véase Sudre, Frédéric, Droit international et européen des droits de l'homme, $5^{\mathrm{e}}$ édition, Paris, PUF, 2001, pp. 182-189; Delzangles, Béatrice, op.cit., nota 29, p. 4. 
rectamente, ha intentado la protección de los DESC con la técnica par ricochet. La técnica de protección par ricochet implica que el tribunal, debido a obstáculos o impedimentos en la protección directa — o en tener ese derecho como violado - , efectúa una protección indirecta del derecho violado, por la vía de otro derecho, el cual en la forma se declara como violado. En efecto, tal como lo ha señalado la profesora Melish "rather than recognizing the autonomous rights of individuals to health, education or adequate housing under the Convention, the Inter-American Court of Human Rights has opted for a canopy approach, subsuming these basic rights, all of which are necessary for the development of a dignified life, into a broadly understood concept of the 'right to life' and, more specifically, the 'right to harbor a project of life"'. ${ }^{103}$

En otras palabras, la Corte IDH ha intentado efectuar una protección de los DESC por la vía de los derechos civiles y políticos. En este sentido, nosotros coincidimos con lo que afirma el profesor Nolan, cuando señala que:

[t]he willingness and capacity of regional bodies to employ civil and political rights standards to indirectly protect ESR, and vice versa, demonstrates the reality that a considerable number of rights including the right to life, the right to equality, trade union rights and property rights, do not conform with any supposed clear-cut categories of ESR and civil and political rights. ${ }^{104}$

En este contexto, la Corte IDH ha protegido y garantizado DESC, cuando se ha invocado como violado, inter alia, el derecho a la vida. Para este efecto, la Corte recurrido a conceptos vinculados al derecho a la vida y que, de hecho, amplían el contenido de dicho derecho, tales como el derecho a una vida digna, las condiciones mínimas de vida y el derecho al proyecto de vida. Esta es una de las vías por las que la Corte IDH ha intentado proporcionar protección a los DESC.

Por ejemplo, la Corte ha señalado en el caso Ximenes Lopes vs. Brasil, de 2006, donde se invocó el derecho a la vida como violado pero se desarrolló, también, un aspecto del derecho a la salud, que "[t]odo tratamiento

${ }^{103}$ Melish, Tara, "The Inter-American Court of Human Rights: Beyond Progressivity”, en Langford (ed.), Social Rights Jurisprudence: Emerging Trends in International and Comparative Law, New York, Cambridge University Press, 2008, pp. 372- 388.

${ }^{104}$ Nolan, Aoife, "Addressing Economic and Social Rights Violations by Non-State Actors through the Role of the State: A Comparison of Regional Approaches to the 'Obligation to Protect'”, Human Rights Law Review, vol. 9, núm. 2, 2009, pp. 225-255, especialmente, p. 253. 
de personas que padecen de discapacidades mentales debe estar dirigido al mejor interés del paciente, debe tener como objetivo preservar su dignidad y su autonomía, reducir el impacto de la enfermedad, y mejorar su calidad de vida". ${ }^{105}$

Por otra parte, cuando hablamos de protección por vía de reparación nos estamos refiriendo a aquellas situaciones en las cuales la Corte IDH intenta proporcionar una forma indirecta de satisfacción de los DESC. Esto lo hace, incluyendo entre las medidas de reparación que ordena en las sentencias, cuando lo estima necesario, medidas que tienden a garantizar, promover y proteger DESC, tales como la construcción de un dispensario de salud en el seno de la comunidad afectada.

En esta línea, en el caso del Tribunal Constitucional vs. Perú, la Corte IDH, proporciona un ejemplo claro de lo señalado, ya que dentro de la reparación, ordenó al Estado pagar los salarios devengados y demás derechos laborales que correspondan. ${ }^{106}$ En el caso Baena Ricardo vs. Panamá, la Corte IDH condenó la aplicación retroactiva de una ley que acarreó “el despido de un amplio número de dirigentes sindicales, con lo cual se afectó gravemente la organización y la actividad de los sindicatos que agrupaban a los trabajadores, y se vulneró la libertad de asociación sindical". ${ }^{107}$ Ade-

${ }^{105}$ Corte IDH, Caso Ximenes Lopes vs. Brasil, Fondo, Reparaciones y Costas, Sentencia del 4 de julio de 2006, Serie C, núm. 149, párrafo 109, p. 31.

106 "Esta Corte ha manifestado, en relación al daño material en el supuesto de víctimas sobrevivientes, que el cálculo de la indemnización debe tener en cuenta, entre otros factores, el tiempo que éstas permanecieron sin trabajar. La Corte considera que dicho criterio es aplicable en el presente caso, y para tal efecto dispone que el Estado debe pagar los montos correspondientes a los salarios caídos y demás derechos laborales que correspondan a los magistrados destituidos, de acuerdo con su legislación”. Corte IDH, Caso del Tribunal Constitucional vs. Perú, Fondo, Reparaciones y Costas, Sentencia del 31 de enero de 2001, Serie C, núm. 71, párrafo 121, p. 54.

107 “158. Esta Corte considera que la libertad de asociación, en materia sindical, reviste la mayor importancia para la defensa de los intereses legítimos de los trabajadores y se enmarca en el corpus juris de los derechos humanos. 159. La libertad de asociación, en materia laboral, en los términos del artículo 16 de la Convención Americana, comprende un derecho y una libertad, a saber: el derecho a formar asociaciones sin restricciones distintas a las permitidas en los incisos 2 y 3 de aquel precepto convencional y la libertad de toda persona de no ser compelida u obligada a asociarse. El Protocolo de San Salvador de 17 de noviembre de 1988, en su artículo 8.3, recoge la misma idea y precisa que, en materia sindical, "[n]adie podrá ser obligado a pertenecer a un sindicato". Corte IDH, Caso Baena Ricardo y otros vs. Panamá, Fondo, Reparaciones y Costas, Sentencia del 2 de febrero de 2001, Serie C, núm. 72, pars. 158 y 159, p. 101 
más, en el caso de los Trabajadores Cesados del Congreso (Aguado Alfaro y otros) vs. Perú, de 2006, la Corte, sin pronunciarse derechamente sobre derechos sociales violados, ordenó, como medida reparatoria, la creación de un órgano independiente e imparcial para que revise los despidos de los trabajadores del Congreso. ${ }^{108}$

En otras palabras, la Corte IDH ha aplicado una especie de protección indirecta o par ricochet de los DESC, ya no tan sólo por la vía de una concepción amplia de ciertos derechos civiles y políticos, sino, en esta ocasión, por medio de las medidas reparatorias. De este modo, resulta interesante observar cómo, mediante las medidas reparatorias ordenadas en sus sentencias, la Corte otorga una suerte de protección de los DESC haciendo que el Estado cumpla con sus obligaciones de respeto, de protección y satisfacción o cumplimiento. Así ocurre, por ejemplo, en el caso, bien conocido, de la "Corte Primera de lo Contencioso Administrativo" de Venezuela, de 2008, relacionado "con la destitución de los ex jueces de la Corte Primera de lo Contencioso Administrativo (en adelante "la Corte Primera") Ana María Ruggeri Cova, Perkins Rocha Contreras y Juan Carlos Apitz Barbera el 30 de octubre de 2003, por haber incurrido en un error judicial inexcusable al conceder un amparo cautelar que suspendió los efectos de un acto administrativo que había negado el registro de una compraventa". ${ }^{109}$

Por último, como se expone a continuación, la Corte IDH ha sido requerida por la Comisión Interamericana de Derechos Humanos para una protección directa, invocando expresamente el artículo 26 de la CADH como violado, pero, en estos casos, la Corte ha declinado declararlo violado. Sin embargo,

108 “148. Sin embargo, en el presente caso el Tribunal considera que la reparación consecuente con las violaciones declaradas es disponer que el Estado garantice a los lesionados en el goce de sus derechos o libertades conculcados, a través del efectivo acceso a un recurso sencillo, rápido y eficaz, para lo cual deberá constituir a la mayor brevedad un órgano independiente e imparcial que cuente con facultades para decidir en forma vinculante y definitiva si esas personas fueron cesadas regular y justificadamente del Congreso de la República o, en caso contrario, que así lo determine y fije las consecuencias jurídicas correspondientes, inclusive, en su caso, las compensaciones debidas en función de las circunstancias específicas de cada una de esas personas". Corte IDH, Caso Trabajadores Cesados del Congreso (Aguado Alfaro y otros) vs. Perú, Excepciones Preliminares, Fondo, Reparaciones y Costas, Sentencia del 24 de Noviembre de 2006, Serie C, núm. 158, párrafo 148, p. 55.

${ }^{109}$ Corte IDH, Caso Apitz Barbera y otros ("Corte Primera de lo Contencioso Administrativo”) vs. Venezuela, Excepción Preliminar, Fondo, Reparaciones y Costas, Sentencia del 5 de agosto de 2008, Serie C, núm. 182, párrafo 2, p. 2. 
en estos mismos casos, la Corte IDH ha avanzado su doctrina sobre DESC, reconociendo principios y estándares aplicables a estos derechos.

En el caso "Cinco Pensionistas" vs. Perú, de 2003, la Corte IDH tuvo la gran oportunidad — lamentablemente perdida — de pronunciarse sobre una violación del derecho al desarrollo progresivo de los derechos económicos, sociales y culturales contenido en el artículo 26 de la CADH, en particular, en lo relativo al derecho a la pensión. ${ }^{110}$ Desde ya, podemos mencionar que derecho humano a un desarrollo progresivo implica una prohibición taxativa de la regresividad.

Recientemente, la Corte IDH ha desarrollado un poco más su doctrina sobre los derechos económicos, sociales y culturales. Se trata del caso de los Cesantes y Jubilados de la Contraloría vs. Perú, de 2009. Este caso se fundó en el

incumplimiento de las sentencias judiciales del Tribunal Constitucional del Perú de 21 de octubre de 1997 y 26 de enero de 2001 que ordenan "que la Contraloría General de la República cumpla con abonar a los integrantes de la Asociación actora las remuneraciones, gratificaciones y bonificaciones que perciben los servidores en actividad de la citada Contraloría que desempeñen cargos idénticos, similares o equivalentes a los que tuvieron los cesantes o jubilados", respecto de doscientos setenta y tres (273) integrantes de la Asociación de Cesantes y Jubilados de la Contraloría General de la República. ${ }^{111}$

Este caso presenta algunas diferencias con respecto al de los "Cinco Pensionistas". Por una parte, en este caso, la Comisión Interamericana de Derechos Humanos (en adelante, la CIDH) no solicitó que se declarara violado el artículo 26 de la $\mathrm{CADH}$, a diferencia de lo ocurrido en el caso de los "Cinco Pensionistas" donde sí efectuó tal petición. Sin embargo, las partes afectadas alegaron el artículo 26 de la CADH como violado. Por otra parte, lamentablemente, en este caso, la Corte IDH prefirió no pronunciarse sobre la violación del referido artículo 26 . No es que la Corte haya rechazado la pretensión de considerar el artículo 26 de la CADH como violado — como

${ }^{110}$ Corte IDH, Caso “Cinco Pensionistas” vs. Perú, Fondo, Reparaciones y Costas, Sentencia del 28 de febrero de 2003, Serie C, núm. 98, párrafo 147, p. 64.

${ }^{111}$ Corte IDH, Caso Acevedo Buendía y otros ("Cesantes y Jubilados de la Contraloría”) vs. Perú, Excepción Preliminar, Fondo, Reparaciones y Costas, Sentencia de 1 de julio de 2009 Serie C, núm. 198, párrafo 2. 
ocurrió en el caso de los Cinco Pensionistas - sino que simplemente aquí no se pronunció.

Sin embargo, la competencia consultiva de la Corte IDH ha constituido una herramienta eficaz para la construcción, en cierne, de una doctrina jurisprudencial sobre los DESC, en particular, sobre los derechos sociales. En efecto, en su Opinión Consultiva sobre la Condición Jurídica y Derechos de los Migrantes Indocumentados, la Corte IDH tuvo la oportunidad de afirmar que "son numerosos los instrumentos jurídicos en los que se regulan los derechos laborales a nivel interno e internacional, la interpretación de dichas regulaciones debe realizarse conforme al principio de la aplicación de la norma que mejor proteja a la persona humana, en este caso, al trabajador". ${ }^{112}$

Asimismo, en nuestra opinión, el tratamiento de los derechos de los pueblos indígenas por la Corte IDH - debiendo necesariamente abordar las relaciones de estas comunidades con su entorno natural- , ha abierto la posibilidad de la consideración de los DESC, especialmente, en el ámbito del control sobre los recursos naturales, la protección del medio ambiente y el reconocimiento de la especificidad cultural indígena. Por ejemplo, en la solicitud de interpretación de la sentencia, en el Caso del Pueblo Saramaka vs. Surinam, la Corte IDH señaló que "la sentencia establece que los EISAs [Estudios Previos de Impacto Social y Ambiental] deben ser concluidos de manera previa al otorgamiento de la concesión, ya que uno de los objetivos de la exigencia de dichos estudios es garantizar el derecho del pueblo Saramaka a ser informado acerca de todos los proyectos propuestos en su territorio. Por lo tanto, la obligación del Estado de supervisar los EISAs coincide con su deber de garantizar la efectiva participación del pueblo Saramaka en el proceso de otorgamiento de concesiones. Además, los EISAs deben ser asumidos por entidades independientes y técnicamente capacitadas, bajo la supervisión del Estado. Finalmente, uno de los factores que debiera tratar el estudio de impacto social y ambiental es el impacto acumulado que han generado los proyectos existentes y los que vayan a

112 "El Estado tiene la obligación de respetar y garantizar los derechos humanos laborales de todos los trabajadores, independientemente de su condición de nacionales o extranjeros, y no tolerar situaciones de discriminación en perjuicio de éstos, en las relaciones laborales que se establezcan entre particulares (empleador -trabajador). El Estado no debe permitir que los empleadores privados violen los derechos de los trabajadores, ni que la relación contractual vulnere los estándares mínimos internacionales”. Corte IDH, Condición Jurídica y Derechos de los Migrantes Indocumentados, Opinión Consultiva OC-18/03 del 17 de septiembre de 2003, Serie A No. 18, párrafo 148, p. 128. 
generar los proyectos que hayan sido propuestos. Este análisis permitiría concluir de una manera más certera si los efectos individuales y acumulados de actividades existentes y futuras pueden poner en peligro la supervivencia de los pueblos indígenas o tribales". ${ }^{113}$

\section{Promoción y reconocimiento del dominio del ius cogens}

Una de las características que singularizan el DADH es la consagración de normas de ius cogens. En efecto, gracias a la actividad dinámica y evolutiva de la Corte IDH en defensa de la dignidad humana, se ha avanzado en el reconocimiento e identificación de normas imperativas de derecho internacional general, siempre dentro de la esfera de los derechos humanos. De esta manera, dos innovaciones que caracterizan las enseñanzas de la Corte IDH residen en el reconocimiento de la prohibición de la discriminación y del principio de igualdad y del derecho de acceso a la justicia como normas de ius cogens. ${ }^{114}$

113 "Para responder con mayor precisión a la preocupación del Estado relativa al estudio previo de impacto social y ambiental ordenado en la Sentencia, la Corte desarrollará con mayor detalle dicha garantía. Los EISAs sirven para evaluar el posible daño o impacto que un proyecto de desarrollo o inversión puede tener sobre la propiedad y comunidad en cuestión. El objetivo de los EISAs no es sólo tener alguna medida objetiva del posible impacto sobre la tierra y las personas, sino también, como se señaló en el párrafo 133 de la Sentencia, "asegura[r] que los miembros del pueblo Saramaka tengan conocimiento de los posibles riesgos, incluidos los riesgos ambientales y de salubridad, a fin de que acepten el plan de desarrollo o inversión propuesto con conocimiento y de forma voluntaria”. Corte IDH, Caso del Pueblo Saramaka vs. Surinam, Interpretación de la Sentencia de Excepciones Preliminares, Fondo, Reparaciones y Costas, Sentencia del 12 de agosto de 2008 Serie C, núm. 185, párrafo 40-41, p. 11; Previamente, en el caso del Pueblo Saramaka vs. Surinam, la Corte IDH había establecido que "[...] el objetivo y el fin de las medidas requeridas en nombre de los miembros de los pueblos indígenas y tribales es garantizar que podrán continuar viviendo su modo de vida tradicional y que su identidad cultural, estructura social, sistema económico, costumbres, creencias y tradiciones distintivas serán respetadas, garantizadas y protegidas por los Estados”. Corte IDH, Caso del Pueblo Saramaka. vs. Surinam, Excepciones Preliminares, Fondo, Reparaciones y Costas, Sentencia del 28 de noviembre de 2007, Serie C, núm. 172, párrafo 121, p. 38.

${ }^{114}$ Podemos encontrar una definición de norma de ius cogens o norma imperativa de Derecho Internacional en la Convención de Viena sobre el Derecho de los Tratados de 1969. Sin embargo, nosotros consideramos esta definición como meramente indicativa o referencial ya que, a nuestro entender, el concepto mismo de norma de ius cogens ha ido evolucionando con el transcurso del tiempo, el progreso del DIDH y el proceso ascendente, propio del siglo XXI, de humanización del Derecho en general, pero, particularmente, 
El principio de prohibición de la discriminación y el principio de igualdad - dos caras de la misma moneda - ha sido reconocido por la Corte IDH como una norma imperativa de derecho internacional. En efecto, en su opinión consultiva sobre la Condición Jurídica y Derechos de los Migrantes Indocumentados, de 2003, la Corte IDH señaló que "[e]1 principio de igualdad ante la ley y no discriminación impregna toda actuación del poder del Estado, en cualquiera de sus manifestaciones, relacionada con el respeto y garantía de los derechos humanos. Dicho principio puede considerarse efectivamente como imperativo del derecho internacional general, en cuanto es aplicable a todo Estado, independientemente de que sea parte o no en determinado tratado internacional, y genera efectos con respecto a terceros, inclusive a particulares. Esto implica que el Estado, ya sea a nivel internacional o en su ordenamiento interno, y por actos de cualquiera de sus poderes o de terceros que actúen bajo su tolerancia, aquiescencia o negligencia, no puede actuar en contra del principio de igualdad y no discriminación, en perjuicio de un determinado grupo de personas". ${ }^{115}$ Además, la Corte IDH aprovechó para recordar la aplicación del efecto horizontal de los derechos humanos y para reiterar que el Estado puede ser tenido responsable por sus propios actos o por actos de terceros particulares.

De este modo, la Corte IDH, en nuestra opinión, de una manera ejemplar, afirma que "que el principio de igualdad ante la ley, igual protección ante la ley y no discriminación, pertenece al jus cogens, puesto que sobre él descansa todo el andamiaje jurídico del orden público nacional e internacional y es un principio fundamental que permea todo ordenamiento jurídico. Hoy día no se admite ningún acto jurídico que entre en conflicto con dicho principio fundamental, no se admiten tratos discriminatorios en perjuicio de ninguna persona, por motivos de género, raza, color, idioma,

del Derecho Internacional. Así, el artículo 53 de la Convención de Viena sobre Derecho de los Tratados señala: "Tratados que están en oposición con una norma imperativa de derecho internacional general (jus cogens). Es nulo todo tratado que, en el momento de su celebración. esté en oposición con una norma imperativa de derecho internacional general. Para los efectos de la presente Convención, una norma imperativa de derecho internacional general es una norma aceptada y reconocida por la comunidad internacional de Estados en su conjunto como norma que no admite acuerdo en contrario y que sólo puede ser modificada por una norma ulterior de derecho internacional general que tenga el mismo carácter".

${ }^{115}$ Corte IDH, Condición Jurídica y Derechos de los Migrantes Indocumentados, Opinión Consultiva OC-18/03 del 17 de septiembre de 2003, Serie A, núm. 18, párrafo 100 , p. 117. 
religión o convicción, opinión política o de otra índole, origen nacional, étnico o social, nacionalidad, edad, situación económica, patrimonio, estado civil, nacimiento o cualquier otra condición. Este principio (igualdad y no discriminación) forma parte del derecho internacional general. En la actual etapa de la evolución del derecho internacional, el principio fundamental de igualdad y no discriminación ha ingresado en el dominio del jus cogens". ${ }^{116}$

La Corte IDH ha reiterado el principio de prohibición de la discriminación y de igualdad como normas imperativas en el caso Yatama, de 2005, precisándolo incluso aun más. Así, la Corte ha afirmado que:

[e]1 principio de la protección igualitaria y efectiva de la ley y de la no discriminación constituye un dato sobresaliente en el sistema tutelar de los derechos humanos consagrado en muchos instrumentos internacionales y desarrollado por la doctrina y jurisprudencia internacionales. En la actual etapa de la evolución del derecho internacional, el principio fundamental de igualdad y no discriminación ha ingresado en el dominio del jus cogens. Sobre él descansa el andamiaje jurídico del orden público nacional e internacional y permea todo el ordenamiento jurídico. ${ }^{117}$

En este mismo caso, la Corte IDH tiene cuidado de precisar cuáles son las obligaciones que emanan para los Estados a partir de esta norma de ius cogens. En efecto, los jueces interamericanos afirmaron que:

[e]se principio posee un carácter fundamental para la salvaguardia de los derechos humanos tanto en el derecho internacional como en el interno; se trata de un principio de derecho imperativo. Por consiguiente, los Estados tienen la obligación de no introducir en su ordenamiento jurídico regulaciones discriminatorias, eliminar las regulaciones de carácter discriminatorio, combatir las prácticas de este carácter y establecer normas y otras medidas que reconozcan y aseguren la efectiva igualdad ante la ley de todas las personas. Es discriminatoria una distinción que carezca de justificación objetiva y razonable. ${ }^{118}$

Además, en el caso Yatama, la Corte IDH se preocupa de resaltar el carácter autónomo de la prohibición de la discriminación y del principio de

${ }^{116}$ Ibidem, párrafo 101, p. 117.

${ }^{117}$ Corte IDH, Caso Yatama vs. Nicaragua. Excepciones Preliminares, Fondo, Reparaciones y Costas, Sentencia del 23 de junio de 2005, Serie C, núm. 127, párrafo 184, p. 85.

${ }^{118}$ Ibidem, párrafo 185, p. 86. 
igualdad de tal manera que un Estado puede ser considerado responsable de acciones $\mathrm{u}$ omisiones discriminatorias o por violación del principio de igualdad. Así, la Corte IDH ha señalado que el:

artículo 24 de la Convención Americana prohíbe la discriminación de derecho o de hecho, no sólo en cuanto a los derechos consagrados en dicho tratado, sino en lo que respecta a todas las leyes que apruebe el Estado y a su aplicación. Es decir, no se limita a reiterar lo dispuesto en el artículo 1.1 de la misma, respecto de la obligación de los Estados de respetar y garantizar, sin discriminación, los derechos reconocidos en dicho tratado, sino consagra un derecho que también acarrea obligaciones al Estado de respetar y garantizar el principio de igualdad y no discriminación en la salvaguardia de otros derechos y en toda la legislación interna que apruebe. ${ }^{119}$

En el caso Servellón García, de 2006, la Corte IDH desarrolló mayormente la teoría de las normas de ius cogens, afirmando específicamente que estas normas generan obligaciones erga omnes y que, por tanto, obligan a todos, Estados e, incluso, particulares. En este sentido, la Corte reafirmó que "[e] ste Tribunal considera que el principio de igualdad ante la ley y no discriminación pertenece al jus cogens el cual, revestido de carácter imperativo, acarrea obligaciones erga omnes de protección que vinculan a todos los Estados y generan efectos con respecto a terceros, inclusive particulares". ${ }^{120}$

La interpretación de la Corte IDH, en cuanto a las normas de ius cogens, ha sido reiterada en la Opinión Consultiva sobre el artículo 55 de la Convención Americana sobre Derechos Humanos, de 2009. En efecto, en la referida opinión consultiva, la Corte reiteró que la prohibición de la discriminación y el principio de igualdad eran normas de ius cogens, cuando ha señalado que:

el Tribunal considera que no podría sostenerse una interpretación de la Convención que atente contra el principio de igualdad y no discriminación, el cual subyace a todos los derechos humanos, y cuya prohibición ha alcanzado carácter de jus cogens. La Corte recuerda, como lo ha hecho en otras oportunidades, que sobre este principio fundamental descansa el andamiaje jurídico del orden público nacional e internacional por lo cual permea todo el ordenamiento jurídico. Con ello, la interpretación reiterada del artículo 55.3 de la

${ }^{119}$ Ibidem, párrafo 186 , p. 87.

${ }^{120}$ Corte IDH, Caso Servellón García y otros vs. Honduras, Fondo, Reparaciones y Costas, Sentencia del 21 de septiembre de 2006, Serie C, núm. 152, párrafo 94, p. 39. 
Convención, aún si constituyera una norma consuetudinaria internacional, no podría tener efectos obligatorios sobre una norma imperativa de derecho. ${ }^{121}$

Desde el punto de vista del derecho de acceso a la justicia - tanto en su aspecto de derecho a un juez como en su dimensión de derecho al derechocomo norma de ius cogens, la Corte IDH ha reconocido expresamente este carácter en el caso Goiburú.

En efecto, en el Caso Goiburú, de 2006, la Corte IDH reconoció el derecho de acceso a la justicia como una norma imperativa de derecho internacional. En efecto, en dicho caso, los jueces interamericanos señalaron que "ante la naturaleza y gravedad de los hechos, más aún tratándose de un contexto de violación sistemática de derechos humanos, la necesidad de erradicar la impunidad se presenta ante la comunidad internacional como un deber de cooperación inter-estatal para estos efectos. La impunidad no será erradicada sin la consecuente determinación de las responsabilidades generales — del Estado-y particulares — penales de sus agentes o particulares-, complementarias entre sí. El acceso a la justicia constituye una norma imperativa de derecho internacional y, como tal, genera obligaciones erga omnes para los Estados de adoptar las medidas que sean necesarias para no dejar en la impunidad esas violaciones, ya sea ejerciendo su jurisdicción para aplicar su derecho interno y el derecho internacional para juzgar y, en su caso, sancionar a los responsables, o colaborando con otros Estados que lo hagan o procuren hacerlo". ${ }^{122}$

Además, en un caso dramático de desaparición forzada de personas y de ejecución extrajudicial en Perú, el caso La Cantuta, de 2006, la Corte IDH confirmó su opinión sobre el derecho de acceso a la justicia. En efecto, en dicho caso, la Corte indicó que "los hechos del presente caso han infringido normas inderogables de derecho internacional (ius cogens). En los términos del artículo 1.1. de la Convención Americana, los Estados están obligados a investigar las violaciones de derechos humanos y a juzgar y sancionar a los responsables. Ante la naturaleza y gravedad de los hechos, más aún tratándose de un contexto de violación sistemática de derechos humanos, la necesidad de erradicar la impunidad se presenta ante la comu-

${ }^{121}$ Corte IDH, Artículo 55 de la Convención Americana sobre Derechos Humanos, Opinión Consultiva OC-20/09 del 29 de septiembre de 2009, Serie A, núm. 20, párrafo 54, p. 59.

${ }^{122}$ Corte IDH, Caso Goiburú y otros vs. Paraguay, Fondo, Reparaciones y Costas, Sentencia del 22 de septiembre de 2006, Serie C, núm. 153, párrafo 131, p. 78. 
nidad internacional como un deber de cooperación interestatal para estos efectos. El acceso a la justicia constituye una norma imperativa de derecho internacional y, como tal, genera obligaciones erga omnes para los Estados de adoptar las medidas que sean necesarias para no dejar en la impunidad esas violaciones, ya sea ejerciendo su jurisdicción para aplicar su derecho interno y el derecho internacional para juzgar y, en su caso, sancionar a los responsables de hechos de esa índole, o colaborando con otros Estados que lo hagan o procuren hacerlo. La Corte recuerda que, bajo el mecanismo de garantía colectiva establecido en la Convención Americana, en conjunto con las obligaciones internacionales regionales y universales en la materia, los Estados Parte en la Convención deben colaborar entre sí en ese sentido". ${ }^{123}$

Luego, ha reiterado esta afirmación en el Caso Anzualdo Castro, de 2009, donde la Corte IDH ha señalado, sin ambages, que:

[e]n estos casos, la impunidad debe ser erradicada mediante la determinación de las responsabilidades tanto generales - del Estado - como individuales penales y de otra índole de sus agentes o de particulares-. En cumplimiento de esta obligación, el Estado debe remover todos los obstáculos, de facto y de jure, que mantengan la impunidad. Las investigaciones deben respetar los requerimientos del debido proceso, lo que implica que el sistema de administración de justicia debe estar organizado de manera tal que su independencia e imparcialidad pueda ser garantizada y que el juzgamiento de graves violaciones a los derechos humanos sea efectuado ante los tribunales ordinarios, para evitar la impunidad y procurar la búsqueda de la verdad. Además, ante la naturaleza y gravedad de los hechos, más aún en contextos de violaciones sistemáticas de derechos humanos, y puesto que el acceso a la justicia constituye una norma imperativa de derecho internacional, la necesidad de erradicar la impunidad se presenta ante la comunidad internacional como un deber de cooperación entre los Estados, que deben adoptar las medidas necesarias para no dejar en la impunidad esas violaciones, ya sea ejerciendo su jurisdicción para aplicar su derecho interno y el derecho internacional para juzgar y, en su caso, sancionar a los responsables, o colaborando con otros Estados que lo hagan o procuren hacerlo. ${ }^{124}$

${ }^{123}$ Corte IDH, Caso La Cantuta vs. Perú, Fondo, Reparaciones y Costas, Sentencia del 29 de noviembre de 2006, Serie C, núm. 162, párrafo 160, p. 85.

${ }^{124}$ Corte IDH: Caso Anzualdo Castro vs. Perú, Excepción Preliminar, Fondo, Reparaciones y Costas, Sentencia del 22 de septiembre de 2009, Serie C, núm. 202, párrafo 125, p. 40. 
Todo lo cual implica, en cierta medida y a nuestro modo de ver, un reconocimiento implícito de una aproximación más alejada del voluntarismo positivista - centrado solamente en el Estado como actor y generador de normas - que ha dominado el derecho internacional clásico. En este sentido, a nuestro parecer, resultan elocuentes las palabras del juez Cançado Trindade, en su voto concurrente en la opinión consultiva sobre el Derecho a la Información sobre la Asistencia Consular, de 1999, donde señaló que:

[s]on ampliamente conocidas y reconocidas las profundas transformaciones por que ha pasado el derecho internacional, en las cinco últimas décadas, bajo el impacto del reconocimiento de los derechos humanos universales. Ya no se sostienen el antiguo monopolio estatal de la titularidad de derechos, ni los excesos de un positivismo jurídico degenerado, que excluyeron del ordenamiento internacional el destinatario final de las normas jurídicas: el ser humano. Se reconoce hoy día la necesidad de restituir a este último la posición central - como sujeto del derecho tanto interno como internacional- de dónde fue indebidamente desplazado, con consecuencias desastrosas, evidenciadas en los sucesivos abusos cometidos en su contra en las últimas décadas. Todo esto ocurrió con la complacencia del positivismo jurídico, en su subserviencia típica al autoritarismo estatal. ${ }^{125}$

Con posterioridad, el juez Cançado Trindade reafirmaría esta posición en su voto disidente en la sentencia sobre excepciones preliminares en el caso de las Hermanas Serrano Cruz, cuando expresa que:

[e]l derecho internacional contemporáneo, al abrigar valores fundamentales compartidos por la comunidad internacional como un todo, ha superado la anacrónica concepción voluntarista, propia de un pasado ya distante en el tiempo. Al contrario de lo que suponen algunos raros y nostálgicos sobrevivientes del apogeo positivista-voluntarista, la metodología de interpretación de los tratados de derechos humanos, desarrollada a partir de las reglas de

125 “Con la desmitificación de los postulados del positivismo voluntarista, se tornó evidente que sólo se puede encontrar una respuesta al problema de los fundamentos y de la validez del derecho internacional general en la conciencia jurídica universal, a partir de la aserción de la idea de una justicia objetiva. Como una manifestación de esta última, se han afirmado los derechos del ser humano, emanados directamente del derecho internacional, y no sometidos, por lo tanto, a las vicisitudes del derecho interno". Corte IDH, El Derecho a la Información sobre la Asistencia Consular en el Marco de las Garantías del Debido Proceso Legal, Opinión Consultiva OC-16/99 del 1 de octubre de 1999, Serie A No. 16, párrafo 12 y 14, p. 5. 
interpretación consagradas en el derecho internacional (tales como las enunciadas en los artículos 31-33 de las dos Convenciones de Viena sobre Derecho de los Tratados, de 1969 y 1986), alcanza tanto las normas sustantivas (sobre los derechos protegidos) como las cláusulas que rigen los mecanismos de protección internacional, - en virtud del principio ut res magis valeat quam pereat - , que corresponde al llamado effet utile (a veces denominado principio de la efectividad), ampliamente respaldado por la jurisprudencia internacional. ${ }^{126}$

Las atrocidades y la envergadura de las violaciones que la realidad regional ha sometido a la Corte IDH han impulsado la consagración de una visión que supere una mera óptica voluntarista del derecho internacional $\mathrm{y}$, sobre todo, de los derechos humanos. Quizá el mensaje que arroja las enseñanzas y la actividad de la Corte IDH es que una protección moderna y acuciosa de los derechos humanos en nuestro continente (y en el mundo entero, por lo demás) requieren del derecho y de los órganos de control una aproximación más estricta a favor de los individuos y grupos vulnerables. En esta línea, el consenso ya no tan sólo es exigido respecto de los Estados sino también de las sociedades directamente como componentes relevantes de una comunidad internacional integrada. En este sentido, y las enseñanzas de la Corte IDH respecto de los pueblos indígenas han sido elocuentes, hoy en día la comunidad internacional no sólo se compone de Estados.

Las enseñanzas de la Corte IDH en el ámbito del ius cogens han alcanzado, incluso, la función propia de un tribunal internacional, considerando tratados internacionales nulos conforme al derecho internacional general debido a ser contrarios a una norma de ius cogens superviniens o ius cogens sobreviniente. ${ }^{127}$ En efecto, en uno de sus primeros casos, el caso Aloeboetoe, la Corte IDH afirmó que:

no considera necesario investigar si dicho convenio [un tratado del 19 de septiembre de 1762 entre el colonizador holandés y la tribu Saramaca (en el actual territorio de Surinam)] es un tratado internacional. Sólo se

${ }^{126}$ Corte IDH, Caso de las Hermanas Serrano Cruz vs. El Salvador, Excepciones Preliminares, Sentencia del 23 de noviembre de 2004, Serie C, núm. 118, Voto Disidente del juez Antonio Augusto Cançado Trindade, párrafo 7, p. 2.

127 “Aparición de una nueva norma imperativa de derecho internacional general ("jus cogens"). Si surge una nueva norma imperativa de derecho internacional general, todo tratado existente que esté en oposición con esa norma se convertirá en nulo y terminará". Artículo 64 de la Convención de Viena sobre el Derecho de los Tratados de 1969. 
limita a observar que si así hubiera sido, el tratado hoy sería nulo por ser contrario a reglas de jus cogens superveniens. En efecto, en ese convenio los saramacas se obligan, entre otras cosas, a capturar los esclavos que hayan desertado, a hacerlos prisioneros y a devolverlos al Gobernador de Suriname, quien les pagará entre 10 y 50 florines por cada uno, según la distancia del lugar de su captura. Otro artículo faculta a los saramacas a vender a los holandeses, en calidad de esclavos, otros prisioneros que pudieren capturar. Un convenio de esta índole no puede ser invocado ante un tribunal internacional de derechos humanos". ${ }^{128}$ En este caso en particular, se trata de la norma imperativa que prohíbe toda clase de esclavitud y que provoca la nulidad del tratado internacional de 1762. Este es un ejemplo que muestra claramente que los derechos humanos configuran y constituyen en la época contemporánea el derecho internacional Constitucional y que los principios que coronan este derecho internacional Constitucional son aquellos que componen el dominio de las normas imperativas o del ius cogens. Como una confirmación de lo expresado precedentemente y de la sintonía transatlántica que existe en materia de principios, la Corte de Justicia de la Comunidad CEDEAO, en África, en el caso Dame Hadjatou Mani Koraou c. Republica de Niger, de 2008, señaló que la esclavitud es considerada como una violación grave de la dignidad humana y que el derecho internacional hace de la prohibición de la esclavitud un derecho intangible, es decir, un derecho absoluto e inderogable. ${ }^{129}$

Todo esto ha contribuido a consolidar la posición de la Corte IDH como un tribunal internacional y un tribunal de derechos humanos, otorgándole visibilidad y respetabilidad en el concierto internacional. A este respecto, resulta interesante mencionar la influencia que la opinión consultiva de la Corte IDH sobre El derecho a la innformación sobre la asistencia consular tuvo en la Corte Internacional de Justica (influencia vertical hacia arriba)

${ }^{128}$ Corte IDH, Caso Aloeboetoe y otros vs. Surinam, Reparaciones y Costas, Sentencia del 10 de septiembre de 1993, Serie C, núm. 15, párrafo 57, p. 15.

${ }^{129}$ Cour de Justice de la CEDEAO, Dame Hadjatou Mani Koraou c. Republica de Niger, Arrêt N ECW/CCJ/JUD/06/08, du 27 octobre 2008, párrafo 75. 
para resolver el caso LaGrand ${ }^{130}$ y posteriormente, el caso Avena. ${ }^{131}$ Ambos casos aprovecharon las enseñanzas de la Corte IDH en el sentido de que el derecho a la información consular contenido en la Convención de Viena sobre Relaciones Consulares de 1963, estaba comprendido dentro del derecho al debido proceso, o bien, del derecho más amplio de acceso a la justicia.

En este sentido, el juez Cançado Trindade ha señalado que:

[1]a Corte Interamericana, mediante su referida opinión consultiva 16 sobre El derecho a la información sobre la asistencia consular en el marco de las garantías del debido proceso legal, de 1999, —emitida al final de un procedimiento consultivo que generó amplia movilización (con ocho Estados intervinientes, además de la Comisión Interamericana de Derechos Humanos $\mathrm{y}$ de diversas organizaciones no gubernamentales e individuos) - , fue efectivamente el primer tribunal internacional a advertir que el incumplimiento del artículo 36(1)(b) de la Convención de Viena sobre Relaciones Consulares de 1963 se daba en perjuicio no sólo de un Estado Parte en dicha Convención sino también de los seres humanos afectados". Además, ha agregado que esta jurisprudencia ha servido de inspiración para la jurisprudencia internacional in statu nascendi sobre la materia. ${ }^{132}$

Por otro lado, también resulta interesante mencionar cómo las enseñanzas de la Corte IDH han tenido repercusión en la Corte EDH (influencia horizontal) por medio de los denominados casos de desapariciones forzadas de personas. Conocido es que la Corte EDH se inspiró de la jurisprudencia de la Corte IDH en materia de desapariciones forzadas de personas, para

130 "Moreover, under Article 36, paragraph 1 (c), the sending State's right to provide consular assistance to the detained person may not be exercised "if he expressly opposes such action". The clarity of these provisions, viewed in their context, admits of no doubt. It follows, as has been held on a number of occasions, that the Court must apply these as they stand. Based on the text of these provisions, the Court concludes that Article 36, paragraph 1, creates individual rights, which, by virtue of Article 1 of the Optional Protocol, may be invoked in this Court by the national State of the detained person. These rights were violated in the present case". I.C.J., LaGrand (Germany v. United States of America), Judgment of 27 June 2001, I. C. J. Reports 2001, párrafo 77, p. 494.

${ }^{131}$ I.C.J., Case concerning Avena and Other Mexican Nationals (Mexico v. United States of America), Judgment of 31 March 2004, I. C. J. Reports 2004, p. 12.

${ }^{132}$ Corte IDH, Condición Jurídica y Derechos de los Migrantes Indocumentados, Opinión Consultiva OC-18/03 del 17 de septiembre de 2003, Serie A No. 18, Voto concurrente del juez A. A. Cançado Trindade, párrafo 1, p. 1. 
enfrentar y resolver los casos de desapariciones forzadas que le comenzaron a llegar, a partir del ingreso de Turquía. ${ }^{133}$

Como se ha visto, el desarrollo del sistema interamericano de promoción y protección de los derechos humanos y la evolución al interior de los Estados de América Latina hacia etapas más avanzadas en los procesos constitucionales, poniendo al ser humano — en especial aquel más vulnerable - en el corazón de la razón de validez del orden constitucional, se ha producido a ritmos similares y de manera paulatina y sistemática. Ahora, abordaremos las influencias, las conexiones y las interrelaciones entre estos dos procesos.

\section{LA INFLUENCIA DEL SISTEMA INTERAMERICANO DE PROTECCIÓN DE LOS DERECHOS HUMANOS SOBRE LOS ÓRDENES NACIONALES Y SUS INTERACCIONES MUTUAS}

La influencia del sistema interamericano de promoción y protección de los derechos humanos sobre los órdenes nacionales, y su interacción mutua, se ha convertido en un elemento principal en el surgimiento de este DADH, al que nos estamos refiriendo, porque ha contribuido a detectar los rasgos o tradiciones constitucionales comunes en materia de derechos humanos, donde existían, y a crearlas o recrearlas - esas tradiciones constitucionales comunes - donde no existían. Con todo, se debe mencionar que estas influencias e interacciones recíprocas se producen también entre el DIDH y los ordenes nacional, en materias tan variadas como los derechos sociales, por ejemplo en el ámbito de los derechos fundamentales del trabajo. ${ }^{134}$ Esto no es sino una manifestación adicional del carácter coherente del derecho de los derechos humanos, cuyo modo de funcionamiento es equivalente tanto en el sistema universal, como en los sistemas especializados y también en los

133 "The Inter-American Court of Human Rights had considered the question of enforced disappearances in a number of cases under the provisions of the American Convention on Human Rights and prior to the adoption of the Inter-American Convention on Forced Disappearance of Persons: Velásquez Rodríguez v. Honduras, Judgment of 29 July 1988 (Inter-Am. Ct. H. R. (Ser. C) no. 4) (1988)); Godínez Cruz v. Honduras, judgment of 20 January 1989 (Inter-Am. Ct. H. R. (Ser. C) no. 5) (1989)); and Cabellero-Delgado and Santana v. Colombia, judgment of 8 December 1995 (Inter-Am. Ct. H. R.)”. E.C.H.R., Case of Kurt v. Turkey (15/1997/799/1002), Judgment, 25 May 1998, párrafo 67.

${ }^{134}$ Cfr. Gravel, Eric y Delpech, Quentin, "Normas del trabajo y complementariedad de los ordenamientos nacionales con el derecho internacional", Revista Internacional del Trabajo, Vol. 127, núm. 4 (2008), pp. 447-461. 
sistemas regionales. Las interacciones e influencias que se han mencionado son una muestra de la vigorosa dinámica actual en las que se encuentran comprometidos los órdenes jurídicos a propósito de los derechos humanos.

Las referidas tradiciones constitucionales comunes en América Latina, hoy en día, se hacen más fuertes, como se verá a continuación, gracias a la guía y la égida de la Corte Interamericana de Derechos Humanos y a su interacción con las jurisdicciones estatales, primordialmente, constitucionales.

\section{Hacia el fortalecimiento de un Estado de derecho con rostro humano en América Latina}

Casi todos los países de América Latina han aceptado la jurisdicción de la Corte Interamericana de Derechos Humanos. Esto ha permitido que en pocas décadas, la Corte IDH haya desarrollado un abundante cuerpo de jurisprudencia - que ilustra el comportamiento y la decisión constitucional de los Estados - y que abarca en profundidad diversos tópicos de los derechos civiles y políticos, proporciona interesantes reglas de interpretación en materia de derechos humanos y dilucida relevantes debates sobre derecho internacional de los derechos humanos, tales como el dominio del ius cogens, o las reparaciones a las violaciones de los derechos humanos.

En términos generales, la incorporación de los Estados de América Latina al sistema interamericano ha ido revelando los problemas heredados de los regímenes autoritarios anteriores, en particular, los problemas derivados de la imposición por esos regímenes a las nuevas transiciones democráticas, de Constituciones de amarre. ${ }^{135}$ Sin duda, ésta es la situación de Chile, en los cuatro casos que, hasta ahora, ha sido condenado ante la Corte IDH, donde se han develado graves problemas en materia de derecho a la libertad de expresión y de información, de excesiva competencia de los tribunales militares, y de la impunidad derivada asimismo de la aplicación de la normativa de amnistía creada por el gobierno militar. ${ }^{136}$

${ }^{135}$ Borea O., Alberto, "Nuevas perspectivas para el tratamiento de los Decretos-Leyes de los gobiernos de facto", Revista del IIDH, núm. 22, julio-diciembre 1995, pp. 51-63.

${ }^{136}$ Corte IDH, Caso "La Última Tentación de Cristo" (Olmedo Bustos y otros) vs. Chile, Fondo, Reparaciones y Costas, Sentencia del 5 de febrero de 2001. Serie C, núm. 73; Corte IDH, Caso Palamara Iribarne vs. Chile, Fondo, Reparaciones y Costas, Sentencia del 22 de noviembre de 2005, Serie C, núm. 135; Corte IDH, Caso Claude Reyes y otros vs. Chile, Fondo, Reparaciones y Costas, Sentencia del 19 de septiembre de 2006 , Serie C, núm. 151; Corte IDH, Caso Almonacid Arellano y otros vs. Chile, Excepciones 
Desde el punto de vista judicial, es posible apreciar que se ha desarrollado un enriquecedor dialogo entre los jueces interamericanos y los jueces constitucionales de América Latina. En esta línea, es necesario aclarar que esta dialéctica vertical entre los jueces constitucionales y los jueces interamericanos no se debería buscar únicamente en citaciones expresas de la jurisprudencia de la Corte. En efecto, es perfectamente posible que las influencias e interacciones mutuas se produzcan, sin que estas aparezcan explicitadas. Dicho de otro modo, no necesariamente porque la jurisprudencia de la Corte IDH no aparece citada en los fallos de los tribunales nacionales, ello significa que las enseñanzas de la Corte IDH no tienen recepción en dicha jurisdicción nacional. El examen de las influencias e interacciones reciprocas debería ir por el lado del impacto de los principios y estándares desarrollados por la Corte IDH, mas que centrarse en la citación expresa de la jurisprudencia de la Corte IDH.

Por ejemplo, en Argentina, la jurisprudencia de la Corte IDH sirvió de sustento a la anulación de las leyes de punto final. En efecto, en el caso Simón, en 2005, la Corte Suprema de Justicia argentina examinó la constitucionalidad de las leyes 23.492 denominada de "punto final" y 23.521 denominada de "obediencia debida" que impedía la investigación y persecución de los crímenes cometidos durante la dictadura. Finalmente, la Corte Suprema argentina declaró inconstitucionales dichas leyes y las privó de cualquier efecto jurídico así como a cualquier acto fundado en ellas. ${ }^{137} \mathrm{En}$ este caso, de modo notable, la Corte Suprema siguió las enseñanzas derivadas de la Corte IDH, inter alia, en el caso Barrios Altos contra Perú, el cual afirmó que:

La promulgación de una ley manifiestamente contraria a las obligaciones asumidas por un Estado parte en la Convención constituye per se una violación de ésta y genera responsabilidad internacional del Estado. En consecuencia, la Corte considera que, dada la naturaleza de la violación constituida por las leyes de amnistía No. 26479 y No. 26492, lo resuelto en la sentencia de fondo en el caso Barrios Altos tiene efectos generales. ${ }^{138}$

Preliminares, Fondo, Reparaciones y Costas, Sentencia del 26 de septiembre de 2006, Serie C, núm. 154.

${ }^{137}$ Simón, Julio Héctor y otros, Corte Suprema de Justicia de la Nación (CS), 14 de junio de 2005, fallos: 328:2056..

${ }^{138}$ El 3 de septiembre de 2001, la Corte Interamericana de Derechos Humanos se pronunció en el caso Barrios Altos, respecto de los efectos de las leyes de amnistía, 26.479 
Además, en este último caso, la Corte IDH reiteró el principio de que: son inadmisibles las disposiciones de amnistía, las disposiciones de prescrip-
ción y el establecimiento de excluyentes de responsabilidad que pretendan
impedir la investigación y sanción de los responsables de las violaciones
graves de los derechos humanos tales como la tortura, las ejecuciones su-
marias, extralegales o arbitrarias y las desapariciones forzadas, todas ellas
prohibidas por contravenir derechos inderogables reconocidos por el DIDH. ${ }^{139}$

Esta misma jurisprudencia fue reiterada por la Corte IDH, respecto de Chile, en el caso Almonacid, de 2006. ${ }^{140}$ Uno de los efectos en Chile, derivados del caso Almonacid, fue que la Corte Suprema de Chile dejó de aplicar, de facto, el Decreto Ley 2.191, denominado ley de amnistía. Sin embargo, aun no se da cumplimiento íntegro a la sentencia de la Corte IDH en cuanto dispone que "el Estado debe dejar sin efecto las citadas resoluciones y sentencias emitidas en el orden interno, y remitir el expediente a la justicia ordinaria, para que dentro de un procedimiento penal se identifique y sancione a todos los responsables de la muerte del señor Almonacid Arellano". ${ }^{141}$

y 26.492. El fallo se debió a una solicitud realizada por la Comisión Interamericana de Derechos Humanos en demanda de interpretación del fallo de la Corte del 14 de marzo de 2001 (sentencia de fondo caso Barrios Altos), ya que el Estado peruano consideraba válidas las leyes de amnistía para todos los casos de violaciones de los derechos humanos, con excepción del caso Barrios Altos. La Corte Interamericana resolvió que la sentencia de fondo en el caso Barrios Altos tiene efectos generales, siendo nulas de nulidad absoluta las leyes de amnistía 26.479 y 26.492 para todos los crímenes contra la humanidad cometidos por el Estado peruano, a través de sus subordinados. La decisión de la Corte Interamericana zanjó así, definitivamente, el tema. Véase Corte IDH, Caso Barrios Altos vs. Perú, Interpretación de la Sentencia de Fondo, Sentencia del 3 de septiembre de 2001, Serie C, núm. 83, párrafo 18 , p. 6.

${ }^{139}$ Corte IDH, Caso Barrios Altos vs. Perú, Fondo, Sentencia del 14 de marzo de 2001, Serie C, núm. 75, párrafo 41, p. 15.

140 “[... ] la Corte estima que los Estados no pueden sustraerse del deber de investigar, determinar y sancionar a los responsables de los crímenes de lesa humanidad aplicando leyes de amnistía u otro tipo de normativa interna. Consecuentemente, los crímenes de lesa humanidad son delitos por los que no se puede conceder amnistía". Corte IDH, Caso Almonacid Arellano y otros vs. Chile, Excepciones preliminares, Fondo, Reparaciones y Costas, Sentencia del 26 de septiembre de 2006, Serie C No 154, párrafo 114, p. 50.

${ }^{141}$ Además, la Corte IDH dispuso que el "Estado no podrá argüir ninguna ley ni disposición de derecho interno para eximirse de la orden de la Corte de investigar y sancionar penalmente a los responsables de la muerte del señor Almonacid Arellano. Chile no podrá volver a aplicar el Decreto Ley 2.191 [...]. Pero además, el Estado no podrá argumentar prescripción, irretroactividad de la ley penal, ni el principio ne bis in idem, así como 
Desde la perspectiva de la actividad legislativa, las sentencias de la Corte IDH han generado cambios legislativos e incluso constitucionales en los Estados sujetos a su jurisdicción, como por ejemplo en el caso de La Última Tentación de Cristo de 2001, donde la Corte ordenó a Chile adecuar su legislación interna a las normas de la Convención Americana sobre Derechos Humanos. ${ }^{142}$ De este modo, en 2001, Chile modificó su Constitución en lo relativo a la libertad de expresión, eliminando la posibilidad de la censura previa. ${ }^{143}$ En un caso más reciente, Chile dictó la ley 20.285 del 20 de agosto de 2008 sobre Acceso a la información pública, adecuando su legislación a las disposiciones de la CADH en materia de libertad de información y acceso a la información pública, de acuerdo con lo dispuesto por la Corte IDH en el caso Claude Reyes y otros, de 2006. ${ }^{144}$

cualquier excluyente similar de responsabilidad, para excusarse de su deber de investigar y sancionar a los responsables". Corte IDH, Caso Almonacid Arellano y otros vs. Chile, Excepciones preliminares, Fondo, Reparaciones y Costas, Sentencia del 26 de septiembre de 2006. Serie C, núm. 154, párrafo 151, p. 60. Corte IDH, Caso Almonacid Arellano y otros vs. Chile. Excepciones preliminares, Fondo, Reparaciones y Costas. Sentencia del 26 de septiembre de 2006. Serie C, núm. 154, párrafo 147, p. 59.

142 “97. Respecto del artículo 13 de la Convención, la Corte considera que el Estado debe modificar su ordenamiento jurídico con el fin de suprimir la censura previa, para permitir la exhibición cinematográfica y la publicidad de la película "La Última Tentación de Cristo", ya que está obligado a respetar el derecho a la libertad de expresión y a garantizar su libre y pleno ejercicio a toda persona sujeta a su jurisdicción.

98. En relación con los artículos 1.1 y 2 de la Convención, las normas de derecho interno chileno que regulan la exhibición y publicidad de la producción cinematográfica todavía no han sido adaptadas a lo dispuesto por la Convención Americana en el sentido de que no puede haber censura previa. Por ello el Estado continúa incumpliendo los deberes generales a que se refieren aquéllas disposiciones convencionales. En consecuencia, Chile debe adoptar las medidas apropiadas para reformar, en los términos del párrafo anterior, su ordenamiento jurídico interno de manera acorde al respeto y el goce del derecho a la libertad de pensamiento y de expresión consagrado en la Convención". Corte IDH, Caso "La Última Tentación de Cristo" (Olmedo Bustos y otros) vs. Chile, Fondo, Reparaciones y Costas, Sentencia del 5 de febrero de 2001, Serie C, núm. 73, pars. 97-98, p. 38.

${ }^{143}$ Ley 19.742 Reforma constitucional que elimina la censura cinematográfica sustituyéndola por un sistema de calificación y que consagra el derecho a la libre creación artística, D.O. 25.08.2001.

${ }^{144}$ En este fallo, la Corte le reiteró a Chile que "[...] el deber general comprendido en el artículo 2 de la Convención implica la supresión tanto de las normas como de las prácticas de cualquier naturaleza que entrañen violaciones a las garantías previstas en la Convención, así como la expedición de normas y el desarrollo de prácticas conducentes a la efectiva observancia de dichas garantías. Por ello, Chile debe adoptar las medidas necesarias para garantizar la protección al derecho de acceso a la información bajo el 
Según la óptica del impacto y seguimiento en la jurisprudencia constitucional, como se ha visto, las interpretaciones y razonamiento de la Corte IDH son seguidas por los jueces constitucionales sobre una base de aumento progresivo.

En efecto, en el caso de Chile, ocasionalmente, el Tribunal Constitucional invoca y se apoya en decisiones de la Corte IDH mientras que, con mayor frecuencia, la jurisprudencia interamericana aparece en los votos disidentes de sus ministros. Desde la perspectiva de los fallos del Tribunal Constitucional chileno, es importante destacar el requerimiento de inconstitucionalidad deducido en contra de algunas disposiciones de las "Normas Nacionales sobre Regulación de la Fertilidad", en donde el Tribunal Constitucional invocó la doctrina establecida por la Corte IDH, en su opinión consultiva núm. 5 de 1985, al señalar que "para dilucidar el conflicto constitucional planteado $\mathrm{y}$ ante la evidencia de estar estos jueces frente a una duda razonable, ha de acudirse a aquellos criterios hermenéuticos desarrollados por la teoría de los derechos fundamentales, por ser ésa la materia comprometida en el presente requerimiento. En tal sentido, parece ineludible tener presente el principio pro homine o favor libertatis definido en la jurisprudencia de la Corte Interamericana de Derechos Humanos de la siguiente forma: "Entre diversas opciones se ha de escoger la que restringe en menor escala el derecho protegido (...) debe prevalecer la norma más favorable a la persona humana". ${ }^{145}$

control del Estado, dentro de las cuales debe garantizar la efectividad de un procedimiento administrativo adecuado para la tramitación y resolución de las solicitudes de información, que fije plazos para resolver y entregar la información, y que se encuentre bajo la responsabilidad de funcionarios debidamente capacitados". Corte IDH, Caso Claude Reyes y otros vs. Chile, Fondo, Reparaciones y Costas, Sentencia del 19 de septiembre de 2006, Serie C, núm. 151, párrafo 163, p. 62.

${ }^{145}$ Tribunal Constitucional: Requerimiento de inconstitucionalidad deducido en contra de algunas disposiciones de las "Normas Nacionales sobre Regulación de la Fertilidad”, aprobadas por el Decreto Supremo N 48, de 2007, del Ministerio de Salud. Rol 740-2007. Sentencia del 18 de abril de 2008. Considerando 66, p. 140; "En consecuencia, si a una misma situación son aplicables la Convención Americana y otro tratado internacional, debe prevalecer la norma más favorable a la persona humana. Si la propia Convención establece que sus regulaciones no tienen efecto restrictivo sobre otros instrumentos internacionales, menos aún podrán traerse restricciones presentes en esos otros instrumentos, pero no en la Convención, para limitar el ejercicio de los derechos y libertades que ésta reconoce". Corte IDH, La Colegiación Obligatoria de Periodistas (Arts. 13 y 29 Convención Americana sobre Derechos Humanos), Opinión Consultiva OC-5/85 del 13 de noviembre de 1985, Serie A, núm. 5, párrafo 52, p. 16. 
En cuanto a las opiniones disidentes, se pueden mencionar los votos de los ministros señores Hernán Vodanovíc Schnake y Jorge Correa Sutil, en el Requerimiento de inaplicabilidad deducido por Carolina Gajardo Salazar respecto del inciso segundo del artículo 387 del Código Procesal Penal, en la causa RIT 2015-2005, seguida ante el Juzgado de Garantía de Talcahuano, por cuasidelito de homicidio, de 2008, quienes estuvieron por acoger el requerimiento sólo en cuanto se inaplica el acápite del inciso segundo del artículo 387 del Código Procesal Penal que establece lo siguiente: "Tampoco será susceptible de recurso alguno la sentencia que se dictare en el nuevo juicio que se realizare como consecuencia de la resolución que hubiere acogido el recurso de nulidad". Para resolver aquello, consideraron dentro de su razonamiento la doctrina establecida, en 2004, por la Corte IDH (Herrera Ulloa con Costa Rica), al declarar que el derecho de recurrir del fallo, consagrado por la Convención, "no se satisface con la mera existencia de un órgano del grado superior al que juzgó y condenó al inculpado, ante el que éste tenga o pueda tener acceso. Para que haya una verdadera revisión de la sentencia, en los términos de dichos instrumentos internacionales, es preciso que el tribunal superior reúna las características jurisdiccionales que lo legitiman para conocer del caso concreto". ${ }^{146}$

En el caso de Perú, el seguimiento de las decisiones de la Corte IDH y la adopción de los criterios provenientes del DIDH es muy interesante. Así, podemos mencionar el caso del Colegio de Abogados del Callao c. Congreso de la República, de 2007, cuyo fallo se apoya en el caso Tribunal Constitucional vs. Perú, ante la Corte IDH, de 1999, en cuanto a la "interpretación de los derechos fundamentales a la luz de los tratados internacionales sobre derechos humanos y de las decisiones de los tribunales internacionales sobre derechos humanos como Derecho Interno", señalando que:

El respeto a los derechos humanos constituye un límite a la actividad estatal, lo cual vale para todo órgano o funcionario que se encuentre en una situación de poder, en razón de su carácter oficial, respecto de las demás personas. Es así, ilícita, toda forma de ejercicio del poder público que viole los derechos

${ }^{146}$ Tribunal Constitucional: Requerimiento de inaplicabilidad deducido por Carolina Gajardo Salazar respecto del inciso segundo del artículo 387 del Código Procesal Penal, en la causa RIT $N^{\circ}$ 2015-2005, seguida ante el Juzgado de Garantía de Talcahuano, por cuasidelito de homicidio. Rol 1130-2007. Sentencia del 7 de octubre de 2008. Voto disidente de los Ministros señores Hernán Vodanovíc Schnake y Jorge Correa Sutil. Considerando 17 , p. 33. 
reconocidos por la Convención. (...). De conformidad con la separación de los poderes públicos que existe en el Estado de derecho, si bien la función jurisdiccional compete eminentemente al Poder Judicial, otros órganos o autoridades públicas pueden ejercer funciones del mismo tipo. Es decir que cuando la Convención se refiere al derecho de toda persona a ser oída por un juez o tribunal competente para la determinación de sus derechos, esta expresión se refiere a cualquier autoridad pública, sea administrativa, legislativa o judicial, que por medio de sus resoluciones determine derechos y obligaciones de las personas. Por la razón mencionada, esta Corte considera que cualquier órgano del Estado que ejerza funciones de carácter materialmente jurisdiccional, tiene la obligación de adoptar resoluciones apegadas las garantías del debido proceso legal en los términos del artículo 8o. de la Convención Americana. ${ }^{147}$

Como se ha señalado, en esta línea de una progresiva dinámica internacional, las jurisdicciones nacionales han comenzado a ser más permeables a los derechos económicos, sociales y culturales, particularmente, en el ámbito de los derechos sociales, del derecho a la educación y del derecho a la salud. Debemos mencionar que este proceso de desarrollo jurisprudencial de los DESC, aunque es loable, es igualmente tardío. Jurisdicciones constitucionales como la francesa hace años que llevan realizando este proceso, por ejemplo, reconociendo el derecho al desarrollo del individuo y de la familia, ${ }^{148}$ en materia de protección de la salud, ${ }^{149}$ en materia de seguridad material, descanso y derecho a la recreación, en cuanto al derecho a los medios convenientes de existencia para el individuo que se encuentra en la incapacidad de trabajar, ${ }^{150}$ en materia de derecho a obtener un alojamiento decente en relación con el respeto de la dignidad humana ${ }^{151}$ y el derecho a obtener un empleo. ${ }^{152}$ En este contexto, Luchaire ha remarcado la interpretación constitucional en el sentido de que:

${ }^{147}$ Corte IDH, Caso del Tribunal Constitucional vs. Perú, Fondo, Reparaciones y Costas, Sentencia del 31 de enero de 2001, Serie C, núm. 71 pars. 68 y 71, pp. 40 y 41.

${ }^{148}$ Véase Décision 325 DC du 13 avril 1993.

${ }^{149}$ Véase Décision 117 DC du 22 juillet 1980.

${ }^{150}$ Véase Décision 325 DC du 13 août 1993; Décision 330 DC du 29 décembre 1993.

${ }^{151}$ Véase Décision 353 DC du 19 janvier 1995.

${ }^{152}$ Véase Décision No 200 DC du 16 janvier 1986; Décision No 207 DC des 25-26 juin 1986. 
la aplicación de los 'principios económicos y sociales que según el Preámbulo de 1946 son particularmente necesarios a nuestro tiempo' permite derogar los derechos y libertades más clásicos y más antiguos a los que se refiere el primer parágrafo del mismo preámbulo. El objetivo de la vivienda decente permite derogaciones al derecho de propiedad; el derecho a obtener un empleo puede limitar la libertad de emprender. ${ }^{153}$

En el contexto latinoamericano, podemos citar ejemplos jurisprudenciales notables, relativamente recientes. En primer lugar, el Tribunal Constitucional chileno se pronunció expresamente sobre el derecho a la salud en el caso de Silvia Peña Wasaff, señalando que:

es también base constitucional y de orden público del contrato de salud la prevista en el artículo 19, 9, de la Carta Política, cuyo inciso final reconoce el derecho de la requirente a elegir el sistema de salud al que desea acogerse. Acorde con la idea de sistema coherente de valores, principios y preceptos ya expuesta, deviene irrebatible que todas las cláusulas del referido contrato deben orientarse a materializar el goce real y legítimo de dicho derecho, más todavía si el afiliado envejece y, a raíz de ello, sube considerablemente el factor respectivo, lo cual repercute en el mayor costo de su plan de salud. Con ello, lejos de permitir el acceso a las prestaciones correlativas, las dificulta y, en el caso extremo, cuando el afiliado, no puede seguir pagando el nuevo costo del plan, cual sucede en la causa aquí decidida, queda obligado a abandonar el sistema privado de salud que había escogido para incorporarse al equivalente público. Obviamente, el hecho descrito significa que el afectado se halla impedido de ejercer tales derechos, a pesar de estarle asegurados por la Constitución en cualquier tiempo y circunstancia. ${ }^{154}$

Por su parte, la Sala Constitucional de la Corte Suprema de Justicia de Costa Rica se ha pronunciado reiteradas veces sobre el derecho a la seguridad social, apoyándose en instrumentos internacionales de derechos humanos. En efecto, esta Sala señaló que:

${ }^{153}$ Luchaire, François, "Le Conseil constitutionnel et l'alternance politique", Revue Française de Droit Constitutionnel, Vol. 57, núm. 1/2004, pp. 9-21, especialmente, p. 20.

${ }^{154}$ Tribunal Constitucional de Chile, Requerimiento de inaplicabilidad deducido por Silvia Peña Wasaff respecto del artículo 38 ter de la Ley 18.933, conocida como Ley de Isapres, en recurso de protección contra Isapre ING Salud S.A., Rol de Ingreso 49722007, de la Corte de Apelaciones de Santiago. Rol No 976-07. Sentencia del 26 de junio de 2008. Considerando 63. 
[1]a seguridad social, esto es, el sistema público de cobertura de necesidades sociales, individuales y de naturaleza económica desarrollado en nuestro país a partir de la acción histórica de la previsión social, estructurada en nuestro país sobre la base de las pensiones y jubilaciones, de la mano de la intervención tutelar del Estado en el ámbito de las relaciones de trabajo ha llegado a convertirse con el tiempo sin la menor reserva, en una de las señas de identidad principales del Estado social o de bienestar. ${ }^{155}$

Por otro lado, la Corte Suprema de Belice, en el caso de la Comunidad Indígena Maya del Distrito de Toledo, en e 2007, reconoció el derecho colectivo de los pueblos indígenas a la propiedad de sus tierras tradicionales y de sus recursos naturales en conexión vital con su derecho colectivo a la identidad cultural y a la supervivencia física y cultural. ${ }^{156}$ Belice es un Estado de America Central que si bien, jurídicamente pertenece al ámbito del common law, es interesante mencionarlo ya que geográficamente, demográficamente, culturalmente y religiosamente, se encuentra muy cercano a la esfera latinoamericana. En consecuencia, en este caso, la Corte Suprema de este país señaló que:

[i]n contemporary international law, the right to property is regarded as including the rights of indigenous peoples to their traditional lands and natural resources. Belize is a party to several international treaties such as the International Covenant on Civil and Political Rights (ICCPR) 999 U.N.T.S. 171; the Convention on the Elimination of All Forms of Racial Discrimination (CERD), 660 UNTS 195; and The Charter of the Organization of American States (OAS) 119 UNTS 3; all of which have been interpreted as requiring states to respect the rights of indigenous peoples over their land and resources». Luego, la Corte Suprema continuó diciendo, “[f]or example, in the case of Mayagna (Sumo) Awas Tingni Community v Nicaragua 79 Inter-Am. Ct.H.R. (Ser C) (2001) that Court held that: "Among indigenous

${ }^{155}$ Caso Exp: 06-009116-0007-CO, Res. 2007017971, Sala Constitucional de la Corte Suprema de Justicia de Costa Rica, 14:51 hrs., del 12 de diciembre de 2007.Parte IV.

156 «I am inclined to agree with the claimants in this respect because, without the legal protection of their rights to and interests in their customary land, the enjoyment of their right to life and their very lifestyle and well-being would be seriously compromised and be in jeopardy. This, I find, will not be in conformity with the Constitution's guarantees». Supreme Court of Belize, Aurelio Cal, et al. v. Attorney General of Belize, (Claim 121/2007) (18 Oct 2007) (Mayan land rights), párrafo 117, p. 58; Campbell, Maia S. and Anaya, S. James, "The Case of the Maya Villages of Belize: Reversing the Trend of Government Neglect to Secure Indigenous Land Rights", Human Rights Law Review, Vol. 8, num. 2 (2008), pp. 377-399. 
peoples there is a communitarian tradition regarding a communal form of collective property of the land, in the sense that ownership of the land is not centered on an individual but rather on the group and its community. Indigenous groups, by the fact of their very existence, have the right to love freely in their own territory; the close ties of indigenous people with the land must be recognized and understood as the fundamental basis of their cultures, their spiritual life, their integrity, and their economic survival. For indigenous communities, relations to the land are not merely a matter of possession and production but a material and spiritual element which they must fully enjoy, even to preserve their cultural legacy and transmit it to future generations". ${ }^{157}$

Resulta aún más interesante este fallo si se considera que Belice es parte de la OEA pero no de la Convención Americana sobre Derechos Humanos. Por tanto, no ha aceptado la jurisdicción de la Corte Interamericana de Derechos Humanos y aun así, recurre a la jurisprudencia y a las enseñanzas de esta Corte, lo que demuestra que sus influencias en los ordenamientos internos de los Estados del Continente (interacción vertical) va mas allá de únicamente aquellos Estados que son formalmente parte de la Convención Americana sobre Derechos Humanos.

Por último, el Tribunal Constitucional de Perú, en el recurso de agravio constitucional interpuesto por Jaime Hans Bustamante Johnson, sentencia del 19 de febrero de 2009, reconoció expresamente el principio de protección medioambiental, el principio de prevención, el principio de desarrollo sostenible y protección de las generaciones futuras, y vinculado con esto, la protección de las comunidades indígenas y su derecho a la identidad étnica y cultural. En este sentido, el Tribunal Constitucional de Perú señaló que:

la consulta debe realizarse antes de emprender cualquier proyecto relevante que pudiera afectar la salud de la comunidad nativa o su hábitat natural. Para ello debe brindársele la información relativa al tipo de recurso a explotar, las áreas de explotación, informes sobre impacto ambiental, además de las posibles empresas que podrían efectuar la explotación del recurso. Estos elementos servirían para que al interior del grupo étnico se inicien las reflexiones y diálogos sobre el plan a desarrollar. Esta información tendrá que entregarse con la debida anticipación para que las reflexiones que puedan surgir sean debidamente ponderadas. Una vez superada esta etapa se podrá dar inició a la etapa de participación propiamente dicha,

${ }^{157}$ Supreme Court of Belize, Aurelio Cal, et al. v. Attorney General of Belize, (Claim 121/2007) (18 Oct 2007) (Mayan land rights), pars. 120-121, p. 59. 
en la que se buscará la dinámica propia del diálogo y el debate entre las partes. Finalmente, la consulta planteada a la comunidad nativa tendrá que ser realizada sin ningún tipo de coerción que pueda desvirtuarla.

Estos criterios han sido también recogidos por la Corte Interamericana en el caso Pueblo de Saramaka vs. Surinam. En dicha sentencia, Además, se estableció que los integrantes de los pueblos indígenas y tribales tenían el derecho de ser titulares de los recursos naturales que tradicionalmente habían usado en su territorio. ${ }^{158}$

Además de estos pronunciamientos jurisprudenciales, cabe mencionar los procesos constitucionales en países como Venezuela con su Constitución en 1999, Ecuador con su nueva Constitución 2008 y Bolivia en el año 2009, donde los derechos económicos, sociales y culturales, y el derecho al medio ambiente, ocupan un lugar destacado. ${ }^{159}$ A pesar de las críticas que se le puedan formular a los procesos constituyentes de estos países, debe destacarse, sin lugar a dudas, los notables avances y desarrollos que estas Constituciones introducen al modelo constitucional latinoamericano, concretizando y encarnando realmente una transición hacia una democracia constitucional comunitaria, donde el factor social y la preocupación por el ser humano como centro de la comunidad, es la principal consideración.

Asimismo, y de manera notable, parecería que la actuación jurisprudencial de la Corte Interamericana de Derechos Humanos ha sido mucho más dinámica que la Corte Europea de Derechos Humanos, lo cual queda en evidencia en temas tan destacados como la apertura de la Corte IDH a abordar la identidad cultural y los derechos humanos de los pueblos indígenas y en el tema de las reparaciones debidas a las víctimas por violaciones a los derechos humanos. En efecto, en la primera situación,

${ }^{158}$ Tribunal Constitucional de Perú, Recurso de agravio constitucional interpuesto por Jaime Hans Bustamante Johnson, Expediente 03343-2007-PA/TC, sentencia del 19 de febrero de 2009, pars. 35-36.

159 “[...] el proceso de constitucionalización de algún tipo de derecho en relación con el medio ambiente ha recibido un impulso cada vez mayor a medida que los estados que, saliendo de diversos tipos de experiencias autoritarias o totalitarias, se dotaban de un sistema democrático y constitucional iban redactando sus nuevas cartas magnas de acuerdo con las tendencias de evolución en el reconocimiento de los derechos humanos en el plano internacional". Vernet, Jaume y Jaria, Jordi, "El derecho a un medio ambiente sano: su reconocimiento en el constitucionalismo comparado y en el derecho internacional", Teoría y Realidad Constitucional, núm. 20, 2007, pp. 513-533, especialmente, p. 528. 
la Corte IDH ha conocido de casos sobre derechos indígenas específicos, tales como, por ejemplo, el derecho del pueblo indígena a la propiedad colectiva de la tierra y territorios. ${ }^{160}$ Además, la Corte IDH ha conocio de casos que si bien, no abordan violaciones de derechos indígenas específicos, los jueces interamericanos sí consideran el elemento de la identidad cultural, al momento de razonar y resolver el caso, como por ejemplo, en el caso Aloeboetoe, Escué Zapata o Yatama. ${ }^{161}$

Toda esta actividad de la Corte IDH ha producido un notable impacto en el orden constitucional de los Estados, donde hoy, son innegables los esfuerzos hacia una mayor tolerancia, pluralismo socio-cultural y jurídico y respeto del multiculturalismo.

En la segunda situación, la jurisprudencia de la Corte IDH ha sido fundamental para el desarrollo, por ejemplo, del estudio que elaboró el profesor Theo van Boven sobre el derecho de restitución, indemnización y rehabilitación de las víctimas de violaciones graves de los derechos humanos y las libertades fundamentales y la subsiguiente aprobación de los Principios y directrices básicos sobre el derecho de las víctimas de violaciones de las normas internacionales de derechos humanos y del derecho internacional Humanitario a interponer recursos y obtener reparaciones. ${ }^{162}$

${ }^{160}$ Corte IDH, Caso de la Comunidad Mayagna (Sumo) Awas Tingni vs. Nicaragua, Fondo, Reparaciones y Costas, Sentencia del 31 de agosto de 2001, Serie C, núm. 79; Corte IDH, Caso de la Comunidad Moiwana vs. Surinam, Excepciones Preliminares, Fondo, Reparaciones y Costas, Sentencia 15 de junio de 2005, Serie C, núm. 124; Corte IDH, Caso Comunidad Indigena Yakye Axa vs. Paraguay, Fondo Reparaciones y Costas, Sentencia 17 de junio de 2005, Serie C, núm. 125; Corte IDH, Caso Comunidad Indígena Sawhoyamaxa vs. Paraguay, Fondo, Reparaciones y Costas, Sentencia del 29 de marzo de 2006, Serie C, núm. 146; Corte IDH, Caso del Pueblo Saramaka. vs. Surinam, Excepciones Preliminares, Fondo, Reparaciones y Costas, Sentencia del 28 de noviembre de 2007, Serie C, núm. 172.

${ }^{161}$ Corte IDH, Caso Aloeboetoe y otros vs. Surinam, cit., Caso Escué Zapata vs. Colombia, Fondo, Reparaciones y Costas, Sentencia del 4 de julio de 2007, Serie C, núm. 165; Corte IDH, Caso Yatama vs. Nicaragua, Excepciones Preliminares, Fondo, Reparaciones y Costas, Sentencia del 23 de junio de 2005, Serie C, núm. 127.

${ }^{162}$ Commission des Droits de l'Homme, Etude concernant le droit à restitution, à indemnisation et à réadaptation des victimes de violations flagrantes des droits de l'homme et des libertés fondamentales, Rapport final présenté par M. Theo van Boven, Rapporteur spécial. U.N. Doc. E/CN.4/Sub.2/1993/8, 2 juillet 1993, pars. 87-92; véase Principios y directrices básicos sobre el derecho de las víctimas de violaciones manifiestas de las normas internacionales de derechos humanos y de violaciones graves del derecho inter- 
En el tiempo presente, se aprecia una incorporación del lenguaje de los derechos humanos, especialmente de aquel desarrollado por la Corte IDH $\mathrm{y}$, en general, por el resto del sistema interamericano de promoción y protección de los derechos humanos, en los debates constitucionales y en la normativa constitucional. A su vez, esta incorporación de lenguaje, pero además, del espíritu, de los principios y normas de los derechos humanos en las Constituciones de América Latina y en la actividad jurisprudencial de sus órganos constitucionales, queda plasmada en el hecho de que la propia Corte IDH cita e invoca las decisiones pronunciadas por diversos tribunales constitucionales o supremos del continente, en materia de derechos humanos, lo que da cuenta de la creciente dinámica de los derechos humanos en el seno de los órganos jurisprudenciales constitucionales. Así, por ejemplo, podemos mencionar al Tribunal Constitucional de Bolivia, ${ }^{163}$

nacional humanitario a interponer recursos y obtener reparaciones, Resolución 60/147 aprobada por la Asamblea General el 16 de diciembre de 2005.

163 "De otra parte, cabe observar que el Tribunal Constitucional de Bolivia ha sido consistente en declarar que los instrumentos internacionales en materia de derechos humanos son parte del bloque de constitucionalidad, así como la jurisprudencia emanada del sistema interamericano de protección a los derechos humanos es vinculante para la jurisdicción interna de Bolivia. En este sentido, dicho Tribunal Constitucional ha considerado que "la privación ilegal de la libertad [...] es un delito permanente [y] consecuentemente para computar los delitos permanentes se debe empezar a contar desde el día en que cesa la ejecución del delito". Esta Corte considera que el Estado no podrá argüir ninguna ley ni disposición de derecho interno para eximirse de su obligación de investigar y, en su caso, sancionar penalmente a los responsables de los hechos cometidos en perjuicio del señor Ticona Estrada. En particular, al tratarse de graves violaciones de derechos humanos el Estado no podrá argumentar prescripción o cualquier excluyente similar de responsabilidad, para excusarse de su deber de investigar y sancionar a los responsables". Corte IDH, Caso Ticona Estrada y otros vs. Bolivia, Fondo, Reparaciones y Costas. Sentencia del 27 de noviembre de 2008, Serie C, núm. 191, párrafo 147, p. 42; "La jurisprudencia internacional refleja también este entendimiento, al igual que varias Cortes Constitucionales de los Estados Americanos. Por ejemplo, la Sala Penal Nacional del Perú ha declarado que "la expresión 'desaparición forzada de personas' no es más que el nomen iuris para la violación sistemática de una multiplicidad de derechos humanos. [...] Se distingue[n] varias etapas en la práctica de la desaparición de personas como [pueden ser] la selección de la víctima, detención de la persona, depósito en un lugar de reclusión, eventual traslado a otro centro de reclusión, interrogatorio, tortura y procesamiento de la información recibida. En muchos casos ocurr[e] la muerte de la víctima y el ocultamiento de sus restos". Corte IDH, Caso Heliodoro Portugal vs. Panamá. Excepciones Preliminares, Fondo, Reparaciones y Costas, Sentencia del 12 de agosto de 2008, Serie C, núm. 186, párrafo 111, p. 31. 
a la Sala Penal Nacional de Perú, ${ }^{164}$ a la Corte Constitucional de Colombia. ${ }^{165}$

Sin embargo, todo este proceso esperanzador, que tiende a alcanzar las condiciones de plena autorrealización del ser humano, no ha estado ni está exento, como se verá a continuación, de dificultades y retrocesos.

\section{Luces y sombras}

¿Cuál es uno de los problemas que presenta el funcionamiento del sistema interamericano de promoción y protección de los derechos humanos? Fuera del problema recurrente de financiación, el cumplimiento y ejecución en el orden nacional de las sentencias de la Corte IDH.

A pesar del grado de evolución importante que han experimentado las Constituciones de los países de América Latina, y del grado de reconocimiento que ellas le proporcionan al DIDH, todavía en el tercer milenio surgen voces que esgrimen el argumento de la soberanía nacional para rechazar el cumplimiento de las sentencias de la Corte IDH. Todo ello a pesar del texto expreso que los propios Estados han aceptado de la CADH en el cual se señala que las sentencias de la Corte IDH son obligatorias y, por lo tanto, ejecutorias. ${ }^{166}$ Por lo demás, los países de la región deben tener presente

164 "Por tratarse de un delito de ejecución permanente, es decir, cuya consumación se prolonga en el tiempo, al entrar en vigor la tipificación del delito de desaparición forzada de personas en el derecho penal interno, si se mantiene la conducta delictiva, la nueva ley resulta aplicable. En este mismo sentido se han pronunciado tribunales de la más alta jerarquía de los Estados del continente americano, como lo son, la Sala Penal Nacional de Perú, el Tribunal Constitucional de Perú, la Suprema Corte de Justicia de México, el Tribunal Constitucional de Bolivia, la Corte Suprema de Justicia de Panamá, el Tribunal Supremo de Justicia de Venezuela y la Corte Constitucional de Colombia, Estados que, al igual que Guatemala, han ratificado la Convención Interamericana sobre Desaparición Forzada". Corte IDH, Caso Tiu Tojín vs. Guatemala, Fondo, Reparaciones y Costas, Sentencia del 26 de noviembre de 2008, Serie C, núm. 190, párrafo 87, p. 30.

165 "Sobre la relación de esta jurisdicción [disciplinaria] con el derecho de acceso a la justicia, la Corte Constitucional de Colombia ha entendido que "si bien la regla general indica que en el derecho disciplinario no existen víctimas por cuanto las faltas remiten a infracciones de deberes funcionales y no a lesiones de derechos, de manera excepcional puede hablarse de víctimas de una falta disciplinaria cuando de la infracción del deber que la constituye surge, de manera inescindible y directa, la violación del derecho internacional de los derechos humanos o del derecho internacional humanitario". Corte IDH, Caso de la Masacre de la Rochela vs. Colombia, Fondo, Reparaciones y Costas. Sentencia del 11 de mayo de 2007, Serie C, núm. 163, párrafo 207, p. 67.

166 “Artículo 68: 1. Los Estados Partes en la Convención se comprometen a cumplir la decisión de la Corte en todo caso en que sean partes. 2. La parte del fallo que disponga 
que el record de satisfacción pronta y oportuna de las sentencias de los tribunales internacionales de derechos humanos, es un elemento relevante a considerar en el examen periódico universal que realiza el Consejo de Derechos Humanos. ${ }^{167}$

Digno de destacar es el caso reciente de Venezuela, con la sentencia dictada por la Sala Constitucional de la Corte Suprema de Justicia que declara inejecutable la sentencia de la Corte IDH y además, dispone que el Estado de Venezuela deba denunciar la CADH. Además, existe el caso de Chile, que aun no da cumplimiento íntegro a la sentencia Almonacid Arellano y a la sentencia Palamara Iribarne. En este contexto, pero excediéndonos del marco geográfico del Cono Sur, resulta digno de destacar la reciente sentencia de la Corte IDH, caso Tiu Tojin contra Guatemala, a raíz del reiterado incumplimiento de un acuerdo sobre reparaciones y de los compromisos adquiridos en el marco de una solución amistosa en el que el Estado reconoció su responsabilidad internacional derivada de los hechos del presente caso. ${ }^{168}$

En el sistema interamericano de protección de los derechos humanos se han planteado casos de denuncia de la Convención Americana sobre Derechos Humanos y, también, de retiro del reconocimiento de la competencia contenciosa de la Corte IDH.

En materia de denuncia, el 26 de mayo de 1998, la República de Trinidad y Tobago comunicó al Secretario General de la OEA su resolución de denunciar la $\mathrm{CADH}$, de conformidad con el artículo 78 de la Convención.

indemnización compensatoria se podrá ejecutar en el respectivo país por el procedimiento interno vigente para la ejecución de sentencias contra el Estado".

167 "Chile mantiene una permanente cooperación con los mecanismos de supervisión del derecho internacional de los derechos humanos, presentando periódicamente sus informes a los órganos de tratados, procurando hacer efectivas sus recomendaciones y adecuando su normativa interna a dichos instrumentos. Asimismo, ha dado cumplimiento a las recomendaciones y sentencias de los órganos interamericanos de derechos humanos, que en un caso significó reformar la Constitución (Caso "Última Tentación de Cristo"); y en otro, la dictación de una Ley de Transparencia y Acceso a Información Pública (Caso "Claude Reyes y otros") que estableció procedimientos, recursos y un organismo -Consejo para la Transparencia- que velará por la aplicación de la citada ley”. Asamblea General: Informe Nacional presentado de conformidad con el párrafo 15 A) Anexo a la resolución 5/1 del Consejo de Derechos Humanos. Doc. N.U. A/HRC/WG.6/5/CHL/1, del 16 de febrero de 2009.

${ }^{168}$ Corte IDH, Caso Tiu Tojín vs. Guatemala, Fondo, Reparaciones y Costas, Sentencia del 26 de noviembre de 2008, Serie C, núm. 190. 
Esta decisión se produjo a raíz de la presentación de reiterados casos sobre la imposición de la pena capital.

En cuanto al retiro del reconocimiento de la jurisdicción contenciosa de la Corte, en junio de 1999, la Corte Suprema de Justicia de Perú, declaró inejecutable la sentencia de reparaciones de la Corte IDH, en el caso Loayza Tamayo, de noviembre de 1988. A raíz de dicho caso y del caso Castillo Petruzzi y otros vs. Perú, en julio de 1999, el Congreso Peruano aprobó por 60 votos a favor un proyecto impulsado por el ex presidente Fujimori, mediante el cual se decide el retiro con efecto inmediato del reconocimiento de la competencia contenciosa de la Corte IDH. En enero de 2001, el Congreso de Perú adoptó la resolución legislativa 27.401, que pide restablecer, para Perú, a plenitud la competencia contenciosa de la Corte.

En efecto, en el caso de Perú, manifestó expresamente su deseo de "retirar" su aceptación de jurisdicción de la Corte IDH, en el caso del Tribunal Constitucional. En la sentencia de competencia, se señaló que:

Mediante nota de 16 de julio de 1999, recibida en la Secretaría de la Corte el 27 de los mismos mes y año, la Secretaría General de la OEA informó que, el 9 de julio de 1999, el Perú había presentado un instrumento en el que comunicaba el retiro de su declaración de reconocimiento de la cláusula facultativa de sometimiento a la competencia contenciosa de la Corte. Asimismo, transmitió copia del original de dicho instrumento, fechado en Lima el 8 de julio de 1999.

En éste, el Ministro de Relaciones Exteriores del Perú señalaba que el Congreso de la República, mediante Resolución Legislativa 27.152 de la misma fecha, había aprobado el retiro en los siguientes términos: “[...] que, de acuerdo con la Convención Americana sobre Derechos Humanos, la República del Perú retira la Declaración de reconocimiento de la cláusula facultativa de sometimiento a la competencia contenciosa de la Corte Interamericana de Derechos Humanos, hecha en su oportunidad por el gobierno peruano". ${ }^{169}$

169 “ $[. .$.$] la Corte considera que es inadmisible el pretendido retiro por el Perú de la$ declaración de reconocimiento de la competencia contenciosa de la Corte con efectos inmediatos, así como cualesquiera consecuencias que se busque derivar de dicho retiro, entre ellas, la devolución de la demanda, que resulta irrelevante". Corte IDH, Caso del Tribunal Constitucional vs. Perú, Competencia, Sentencia del 24 de septiembre de 1999, Serie C, núm. 55 pars. 27 y 53, pp. 9 y 14. 
Recientemente, Venezuela ha amenazado con denunciar la CADH, después de que la Sala Constitucional del Tribunal Supremo de Justicia declaró - del 18 de diciembre de 2008 - inejecutable una sentencia de la Corte IDH a favor de tres ex jueces. En efecto, el máximo Tribunal Venezolano expresó que "esta Sala Constitucional declara inejecutable el fallo de la Corte Interamericana de Derechos Humanos, del 5 de agosto de 2008, en la que se ordenó la reincorporación en el cargo de los ex magistrados de la Corte Primera de lo Contencioso Administrativo Ana María Ruggeri Cova, Perkins Rocha Contreras y Juan Carlos Apitz B.; con fundamento en los artículos 7, 23, 25, 138, 156.32, el capítulo III del título V de la Constitución de la República y la jurisprudencia parcialmente transcrita de las Salas Constitucional y Político Administrativa". ${ }^{170}$

Además, más sorprendente aún en este caso, la Sala Constitucional venezolana solicitó al Gobierno que denuncie la $\mathrm{CADH}$, al expresar que:

con fundamento en el principio de colaboración de poderes (artículo 136 de la Constitución de la República Bolivariana de Venezuela) y de conformidad con lo dispuesto en el artículo 78 de la Convención Americana sobre Derechos Humanos, se solicita al Ejecutivo Nacional proceda a denunciar este Tratado o Convención, ante la evidente usurpación de funciones en que ha incurrido la Corte Interamericana de los Derechos Humanos, con el fallo objeto de la presente decisión. ${ }^{171}$

Resulta muy interesante y esclarecedor, el voto disidente del Magistrado Pedro Rafael Rondón Haaz, quien muestra las contradicciones de la sentencia arriba referida, al señalar que "[c]on especial énfasis, por último, se aparta quien disiente de la solicitud al Ejecutivo Nacional de que "proceda a denunciar" la Convención Americana sobre Derechos Humanos "en función de la evidente usurpación de funciones en que ha incurrido la Corte Interamericana de Derechos Humanos, con el fallo objeto de la presente decisión." Más allá de que no se comparte la existencia de una evidente usurpación

${ }^{170}$ Véase Sala Constitucional del Tribunal Supremo de Justicia de Venezuela, Magistrado Ponente: Arcadio Delgado Rosales, Expediente No. 08-1572. Sentencia del 18 de diciembre de 2008; Corte IDH, Caso Apitz Barbera y otros ("Corte Primera de lo Contencioso Administrativo”) vs. Venezuela, Excepción Preliminar, Fondo, Reparaciones y Costas, Sentencia del 5 de agosto de 2008, Serie C, núm. 182.

${ }^{171}$ Véase Sala Constitucional del Tribunal Supremo de Justicia de Venezuela, Magistrado Ponente: Arcadio Delgado Rosales, Expediente No. 08-1572, Sentencia del 18 de diciembre de 2008 . 
de funciones por parte de la Corte Interamericana de Derechos Humanos, se hace un flaco servicio al Estado cuando se le coloca en incumplimiento con sus obligaciones nacionales (artículos 30 y 31 de la Constitución) e internacionales (artículo 68 de la Convención Americana sobre Derechos Humanos) en materia tan sensible como los derechos humanos que, paradójicamente, gozan de una protección ejemplar en nuestra Constitución, cuyo texto se reduce a eso, sólo un texto, cuando se le desconoce. Por otra parte, resulta desconcertante que la sentencia reconozca la vigencia de la Convención y su rango constitucional dentro del derecho interno; la diferencia entre ese tratado y los informes, opiniones y decisiones que se dicten con ocasión de su aplicación; que declare que "no se trata de interpretar el contenido y alcance de la sentencia de la Corte Interamericana de Derechos Humanos, ni de desconocer el tratado válidamente suscrito por la República que la sustenta o eludir el compromiso de ejecutar las decisiones según lo dispone el artículo 68 de la Convención Americana sobre Derechos Humanos" y, en el mismo veredicto, los mismos sentenciadores estimen que debe denunciarse la Convención a causa de un supuesto exceso, no del acuerdo multilateral en sí, sino de un acto distinto". ${ }^{172}$

Es interesante resaltar que el no cumplimiento de las sentencias de la Corte IDH implica la realización de hechos internacionalmente ilícitos que ponen en juego la responsabilidad internacional del Estado. Además, el referido incumplimiento es una fuente de impunidad, promovida por la actitud del Estado, que, además de no perseguir al responsable de la conducta ilícita, puede generar la ausencia de satisfacción de otras consecuencias jurídicas del fallo, tales como reformas legislativas, invalidación de procesos, modificación de reglamentos, políticas y programas, entrega de reparación a las víctimas, etc. Así, García Ramírez, explicando la impunidad ha señalado que "[s]e trata de señalar el fenómeno que se presente cuando los delincuentes no reciben el castigo - la pena, la punición - que corresponde a su conducta ilícita. Ahora bien, en una acepción más amplia habría que reelaborar el concepto —y probablemente redefinirlo - a fin de que abar-

${ }^{172}$ Véase Sala Constitucional del Tribunal Supremo de Justicia de Venezuela, Magistrado Ponente: Arcadio Delgado Rosales, Expediente No. 08-1572, Sentencia del 18 de diciembre de 2008, Voto disidente del Magistrado Pedro Rafael Rondón Haaz, Considerando $9^{\circ}$. 
que la omisión de cualquier medida que sea consecuencia de la violación cometida y declarada por la autoridad competente". ${ }^{173}$

La disconformidad interna con los fallos de la Corte IDH, no es un rasgo exclusivamente del continente americano, ya que en el sistema europeo de protección de los derechos fundamentales también se presentan. Sin embargo, hay dos diferencias fundamentales, por un lado, este tipo de situaciones es esporádico o infrecuente. Por otro lado, cuando ocurren estas disconformidades, nadie plantea siquiera abandonar el sistema europeo de protección de los derechos humanos. ${ }^{174}$ En consecuencia, el problema que surge en el continente americano y la preocupación que se puede manifestar dice relación con la insistencia de los Estados en cuanto a amenazar abandonar el sistema interamericano de protección, lo cual no sólo resquebraja la fortaleza del sistema sino que además, desde el punto de vista interno de los Estados, da cuenta de una falta de madurez constitucional, de un posible retroceso en el proceso democratizador y de una debilidad en las instituciones constitucionales. También surgen voces que buscan argumentos para justificar el incumplimiento de las decisiones de los órganos internacionales, en este caso, de la Corte IDH, por parte de los jueces nacionales, apoyándose en la doctrina del margen de apreciación nacional, que eventualmente le proporcionaría un grado de discrecionalidad al juez del foro para decidir si cumple o no cumple, cómo y cuándo cumple. ${ }^{175}$

${ }^{173}$ García Ramírez, Sergio, "La jurisprudencia de la Corte Interamericana de Derechos Humanos en materia de reparaciones", en Corte Interamericana de Derechos Humanos, La Corte Interamericana de Derechos Humanos: Un cuarto de siglo: 1979-2004, San José, 2005, pp. 1-85, especialmente, p. 75.

${ }^{174}$ Se debe tener presente que el consenso común en Europa, recordado por el Parlamento Europeo reiteradamente, es que "la democracia se basa en el pleno respeto de los derechos humanos y las libertades fundamentales y en la plena aplicación del principio de la legalidad y en el Estado de Derecho; pide, por consiguiente, a los Estados miembros y a las instituciones de la UE que garanticen el pleno respeto de las disposiciones de los tratados internacionales en materia de derechos humanos y, en particular, el Convenio Europeo para la Protección de los Derechos Humanos y de las Libertades Fundamentales (CEDH) y sus protocolos, junto con sus respectivas Constituciones y legislaciones". Resolución del Parlamento Europeo sobre la situación de los derechos fundamentales en la Unión Europea (2001) (2001/2014(INI)).

${ }^{175}$ En el caso de la doctrina chilena, vid. Núñez Poblete, Manuel, "Introducción al concepto de identidad constitucional y a su función frente al Derecho supranacional e Internacional de los Derechos de la persona”, Revista Ius et Praxis, año 14, núm. 2 (2008), pp. 331-372. 
Para la consolidación de un verdadero Estado constitucional democrático es necesario avanzar en los proceso de respeto y protección creciente de los derechos humanos. En este sentido Pérez Luño ha señalado que "el Estado constitucional no sólo se caracteriza por ser la forma política que consagra la primacía de la Constitución, la reserva de Constitución y el protagonismo de la jurisdicción constitucional, sino que es también el marco jurídico-político de reconocimiento y garantía de los derechos de la tercera generación". ${ }^{176}$

Resultaría conveniente que los Estados del continente regularan, deseablemente mediante reformas constitucionales, la obligación que han asumido de cumplir y ejecutar las sentencias de la Corte IDH. Sólo algunos Estado han incorporado en sus ordenamientos normas en esta línea. Por ejemplo, se pueden citar Costa Rica, en el Convenio de sede entre el Gobierno de la República de Costa Rica y la Corte Interamericana de Derechos Humanos, de 10 de septiembre de 1981, ratificado por ley 6.889; Colombia, por medio de la ley 288, del 5 de julio de 1996, y el Decreto 321, de 25 de febrero de 2000; y Perú, artículo 115 del Código Procesal Constitucional —aprobado por ley 28.237, publicada el 31 de mayo de 2004 - y ley 27.775, publicada el 7 de julio de 2002. Se han presentado algunas otras iniciativas en este sentido, entre las que cabe destacar el proyecto chileno de Acciones Protectoras de derechos fundamentales, aprobado por la Comisión de Derechos Humanos de la Cámara de Diputados y en discusión ante la Comisión de Legislación, Constitución y Justicia de la misma Cámara, el cual señala en su artículo 128 que las "sentencias de Cortes Internacionales o Supranacionales en materia de derechos humanos a la que el Estado de Chile le haya reconocido jurisdicción contenciosa vinculante son de obligatorio cumplimiento por los órganos del Estado de Chile". En este contexto, junto con el profesor Bazán, podemos señalar que la voluntad política debiera concurrir para complementar el orden constitucional de los derechos fundamentales, por medio de la generación de una norma que indicara de forma clara el procedimiento interno de ejecución de las recomendaciones de la Comisión Interamericana de Derechos Humanos y de la Corte IDH. ${ }^{177}$

${ }^{176}$ Pérez Luño, Antonio Enrique, op.cit., nota 10, p. 1258.

${ }^{177}$ Bazán, Víctor, "La Corte Suprema de Justicia argentina y su rol en la articulación del DIDH y el Derecho interno", Revista de Derecho Político, núm. 73, septiembrediciembre 2008, pp. 315-373, especialmente, p. 367. 
Con todo, cabe destacar la vitalidad creciente que ha ido adquiriendo el sistema interamericano de protección de los derechos humanos, por medio del reconocimiento de la fuerza vinculante de las recomendaciones de la Comisión Interamericana de Derechos Humanos, como por ejemplo, en los casos de Brasil, ${ }^{178}$ Belice ${ }^{179}$ y El Salvador. ${ }^{180}$

El individuo hoy ocupa un lugar preferente y privilegiado en la construcción del derecho constitucional y del derecho internacional. En consecuencia, los Estados de América Latina, en virtud del principio de cooperación leal con la Corte IDH, deben contribuir y facilitar lealmente el desempeño de la Corte y, luego, dar cumplimiento efectivo a las sentencias de la misma. ${ }^{181}$

\section{CONCLUSIONES}

El DADH, en proceso de surgimiento, se nutre de las tradiciones constitucionales comunes, reconocidas ya en el preámbulo de la Convención Americana sobre Derechos Humanos y de los valores y principios recogidos en los instrumentos internacionales. Este orden jurídico de los derechos humanos representa un umbral mínimo que determina el mínimo común denominador para los Estados de América Latina, por lo que, evidentemente, sus propios ordenes constitucionales podrían, perfectamente, $-\mathrm{y}$ así sería deseable - establecer un estándar de derechos humanos más elevado.

Este estándar mínimo de derechos humanos compone y configura un espacio público americano, que desde el punto de vista normativo, se llena de

${ }^{178}$ Brasil, Segundo informe periódico presentado por los Estados Partes de conformidad con los artículos 16 y 17 del Pacto, Comité de Derechos Económicos, Sociales y Culturales, E/C.12/BRA/2, 28 de enero de 2008.

${ }^{179}$ Supreme Court of Belize, A.D.2007, Consolidated Claims, Claim No.171 of 2007, Aurelio Cal in his own behalf and on behalf of the Maya Village of Santa Cruz [...] and the Attorney General of Belize and the Minister of Natural Resources and Environment, Claim No.172 of 2007, Manuel Coy in his own behalf [...], párrafo100.

${ }^{180} \mathrm{Al}$ culminar su $137^{\circ}$ periodo de sesiones (noviembre 2009), la Comisión Interamericana de Derechos Humanos ha valorado muy positivamente que el Estado de El Salvador hubiera efectuado una aceptación explicita del carácter vinculante de las decisiones de la Comisión.

${ }^{181}$ Sobre el principio de cooperación leal, vid. Nohlen, Nicolas, "Germany: The European Arrest Warrant Case", International Journal of Constitutional Law, vol. 6, núm. 1 (2008), pp. 153-161; “26."Pacta sunt servanda". Todo tratado en vigor obliga a las partes y debe ser cumplido por ellas de buena fe". Convención de Viena sobre el derecho de los tratados, Viena, 1969. 
contenido por medio del orden público americano. El orden público americano fija el marco jurídico mínimo dentro del cual los Estados — constitucionales y democráticos - americanos pueden moverse para alcanzar grados avanzados de justicia social. A través del DADH, el Estado latinoamericano es un Estado democrático y comunitario, gracias al fuerte contenido humanista, que el especial sentido de comunidad existente en el continente, le impregna a los derechos humanos, especialmente, a los DESC. Dicho de otro modo, los derechos humanos, particularmente, los DESC, son leídos en América Latina a la luz del fuerte sentido de comunidad que existe en la región, en cuyo seno se aloja un poderoso componente de solidaridad. Esto último explica que el Estado constitucional latinoamericano sea visto, desde la óptica del DADH, como un Estado democrático y comunitario de derechos.

El desafío que se le plantea a los Estados de América Latina es seguir avanzando en este proceso creciente de confluencia del orden constitucional con el orden internacional de los derechos humanos, dándole aplicabilidad práctica y efectividad real a todos los derechos humanos, incluso, a los DESC, sin distinciones caprichosas. En este sentido, el Estado, principalmente, por medio de sus órganos jurisdiccionales, tiene el deber primordial de proporcionar al individuo o grupo una tutela judicial rápida, oportuna y eficaz de todos los DESC, y de esa manera, convertir a la Constitución - por vía pretoriana - en una Constitución "efectivamente vivida".

Para enfrentar estos desafíos en el tercer milenio, aparece como necesario seguir avanzando por la senda del fortalecimiento y consolidación de una verdadera cultura 'de a pie' de los derechos humanos, en el sentido de que sean los individuos y pueblos quienes se apropien de sus derechos y los reivindiquen ante los agentes del Estado y ante terceros. En este ámbito, el Estado - Ejecutivo, Legislativo y Judicial - tiene un rol activo que jugar, precisamente en el área de los DESC, por medio de la enseñanza de los derechos humanos y la educación en derechos humanos.

Por último, un foco claro de preocupación dentro del espacio público americano - que va contracorriente - son los episodios de rebeldía, y a veces de clara enemistad, con respecto al sistema interamericano de derechos humanos, en particular, frente a las sentencia de la Corte Interamericana de Derechos Humanos. No deja de sorprender, y esto marca una clara diferencia con la cultura jurídico-constitucional de los países de Europa occidental, los episodios de puesta en tela de juicio del sistema interamericano de derechos humanos, cuando, en la ocurrencia, el Estado resulta vencido y condenado 
por violación de la Convención Americana sobre Derechos Humanos. No puede sino dejarnos perplejos la falta de madurez constitucional y la fragilidad de los compromisos y del Estado constitucional-democrático, que ello demuestra, cada vez que un Estado condenado, esgrime el argumento del abandono del sistema interamericano de derechos humanos. La reflexión que se puede hacer aquí es: ¿qué Estado es más democrático? ¿Aquel que se somete al escrutinio jurídico internacional o aquel que lo rechaza? Nuestra perspectiva es que aquellos que se someten a grados elevados de escrutinio jurisdiccional representan estadios más avanzados del proceso democratizador. En consecuencia, se plantea como un desafío muy importante, el acatamiento y cumplimiento de buena fe, de las decisiones provenientes del sistema interamericano de promoción y protección de los derechos humanos. Esta obligación de acatamiento no debe examinarse como una amenaza a la soberanía de los Estados, ya que el Estado ha aceptado expresamente este escrutinio internacional.

El estándar mínimo americano, determinado por el sistema interamericano de promoción y protección de los derechos humanos, $\mathrm{y}$, en particular, por la actividad de la Corte IDH e integrado, además, por las tradiciones constitucionales comunes de los Estados, debiera incorporarse en las Constituciones de los Estados americanos, configurando, a su vez, el estándar constitucional mínimo en materia de derechos humanos del constitucionalismo democrático y comunitario americano del tercer milenio. Así, parafraseando a Rawls, esta concepción común de la justicia de los derechos humanos constituiría la base del modelo de democracia constitucional americana. ${ }^{182}$

El espacio público americano que configura un orden publico americano y que determina estándares mínimos realizables en las comunidades estatales del continente, conduce a preguntarse cuáles serían las tradiciones constitucionales comunes de los Estados - a la que se refiere la Declaración Americana de Derechos y Deberes del Hombre - en materia de derechos humanos. ¿Estas tradiciones constitucionales comunes habría modelado el DADH? O bien, ¿el derecho de la Corte IDH habría modelado las tradiciones constitucionales comunes? Nuestra respuesta liminar apuntaría a que en esta sociedad de la instantaneidad, las interacciones han sido reciprocas.

Entonces, el estándar mínimo americano, la solidaridad a la base de la composición de nuestras sociedades y en el sustratum de la conciencia jurídica americana y el sentido especialmente fuerte de comunidad (derechos

${ }^{182}$ Rawls, John, op.cit, nota 44, p. 229. 
y deberes), arrojan una concepción común o compartida de la justicia de los derechos humanos, que podría configurar la base del modelo de democracia constitucional latinoamericana. En consecuencia, surge una nueva interrogante, a partir de esta base común de justicia y, eventualmente, de democracia constitucional, comunitaria y multicultural, qué principios constitucionales comunes se podrían inferir. 